\title{
HILGARDIA
}

A Journal of Agricultural Science Published by the California Agricultural Experiment Station

\section{FORMULAS AND TABLES \\ TO FACILITATE THE CALCULATION OF RECOMBINATION VALUES IN HEREDITY}

R. W. ALLARD 
This study provides the following aids for using the method of maximum likelihood to estimate recombination values and examine heterogeneity when complex genetic data are available:

Estimation equations for a variety of backcross, $F_{2}$, and F: situations, including equations for estimating linkage intensities between a member of a complementary or duplicate pair, or a gene pair producing a 13:3 ratio, and a third gene pair;

Tables of scores to facilitate the numerical solution of these equations;

Tables to facilitate the calculation of the standard error of the recombination value.

Since advance planning is important in linkage investigations, the use of the tables for this purpose is also described. 


\section{H I L}

A Journal of Agricultural Science Published by

the California Agricultural Experiment Station

VoL. 24

JANUARY, 1956

No. 10

\section{FORMULAS AND TABLES TO FACILITATE THE CALCULATION OF RECOMBINATION VALUES IN HEREDITY ${ }^{1}$}

\section{R. W. ALLARD}

The most USEFUL Methoins for estimating recombination values in heredity are the product moment method and the method of maximum likelihood (Fisher and Balmukand, 1928). The product method is simple to apply in conjunction with tables such as those calculated by Immer (1930), Stephens (1939), and Immer and Henderson (1943), but the method is limited to cases where 4-class segregations occur. The method of maximum likelihood, on the other hand, is quite general and may be applied to any genetic data providing information about linkage. The method is also applicable if more than one type of data is available.

When such complex data are encountered, the estimation of the recombination value and the examination of heterogeneity are both facilitated by the use of scores based on the method of maximum likelihood (Fisher, 1946). In connection with linkage investigations at the University of California, Davis, over the past several years, maximum-likelihood equations have been derived for a wide variety of genetic situations, and tables of scores have been calculated to facilitate the solutions of these equations. Formulas for the calculation of standard errors of recombination values have also been derived and tables prepared facilitating their calculation. The purpose of this paper is to make these equations and tables generally available and to provide a numerical example of their use. Because of the importance of planning in linkage experiments, the use of the tables for this purpose is described.

Mather $(1935,1951)$ has discussed in detail the combination of data in estimating recombination values. In brief, the method requires that the logarithms of the probabilities of obtaining the observed families be maximized with respect to the parameters to be estimated; this is accomplished by differentiating partially with respect to each parameter in turn, equating the derivatives to zero, and solving the resulting set of simultaneous equations. Assuming that the various sets of data pertain to a single recombination value, the estimation equation takes the form

$$
\frac{d L}{d p}=a_{1} \frac{d \log m_{1}}{d p}+a_{2} \frac{d \log m_{2}}{d p}+\cdots+a_{t} \frac{d \log m_{t}}{d p}=0
$$

${ }^{1}$ Received for publication September 12, 1954.

${ }^{2}$ Associate Professor of Agronomy and Associate Agronomist in the Experiment Station, Davis. 
where $p$ represents the recombination fraction, $a_{1}$ and $m_{1}$ the observed and expected numbers, respectively, in the first of the $t$ distinguishable classes, etc. ${ }^{3}$ The use of scores in the solution of estimation equations depends upon

the fact that $\frac{d \log m_{1}}{d p}, \frac{d \log m_{2}}{d p}$, etc., each have a unique value for any given $p$, this value (or score) representing the contribution one individual in a particular class makes to the derivative of the logarithm of the likelihood expression. The product obtained by multiplying this score by the observed number in a class gives the total contribution (or total score) of the class to the derivative. The solution of the equation is clearly provided by the value of $p$ for which the total scores sum to zero.

The symbols used to represent the observed and expected frequencies for various genotypes and phenotypes can be found in tables 4 and 5 . It has been convenient to follow Immer (1934) in using the symbols $a, b, c \ldots \ldots$. to represent observed frequencies. Estimation equations for a variety of types of genetic families are summarized in table 6, and scores for the majority of the classes likely to be encountered in linkage studies are in table 7 . In the text and table 6 , certain types of families are identified by the ratios they produce when $p=0.50$, that is, when the genes involved are independent. Lack of suitable terminology made this necessary.

It can be shown that the mean amount of information, $i_{\mathrm{p}}$, supplied by a single individual in an $\mathrm{F}_{2}$ family (or by a single $\mathrm{F}_{3}$ family) is given by $i_{p}=-\sum\left(m \frac{d^{2} \log n}{d p^{2}}\right)$ or alternatively by $i_{p}=\sum\left[\frac{1}{m}\left(\frac{d m}{d p}\right)^{2}\right]$. Since $i_{p}$ depends only on the value of $p$, it is readily tabulated and need only be multiplied by $n$, the number of individuals in the family, to obtain $I_{p}$, the total amount of information provided by the $\mathrm{F}_{2}$ family. $I_{p}$ is the inverse of the variance so that $\mathrm{V}_{\mathrm{p}}=\frac{1}{I_{p}}$. Hence the standard error of $p$ is

$$
s_{p}=\sqrt{V_{p}}=\sqrt{\frac{1}{I_{p}}}=\sqrt{\frac{1}{n i_{p}}} .
$$

Mean amounts of information $\left(i_{p}\right)$ supplied by a single $\mathrm{F}_{2}$ individual in a number of types of families at various values of $p$ are in table 8 .

\section{APPLICATION OF THE TABLES}

The application of the tables can be illustrated by using some unpublished data from lima beans. The genes involved are $\mathrm{D}$ vs. $d$ (determinate vs. indeterminate growth habit) and R vs. r (dark red vs. red seed coat) (Allard, $1953 a$ and $b$ ).

The first data concerning the linkage relations of these gene pairs to become available were the three sets of $\mathrm{F}_{2}$ coupling data shown in table 1 . These data suggested that the two gene pairs might be linked. Accordingly, a

\footnotetext{
s Throughout this paper "log" means "loge."
} 
precise test for independence was made by a $\chi^{2}$ analysis. The $\chi^{2}$ value associated with interaction was highly significant, indicating linkage. The recombination value was then calculated by the product method and found to be $41 \pm 1.42$ per cent. Further, it was determined by a $3 \times 4$ contingency table that the data are homogeneous. Over a period of several years additional data concerning linkage between these gene pairs became available, mostly incidental to other studies. Finally the nine bodies of data summarized in table 1 were at hand for the estimation of the recombination value. The data represent six different parental combinations grown in five different seasons. It should be noted that these data include six different types of genetic families.

Once these various bodies of data were available, it became desirable, of course, to use all of them in determining the recombination value. The first step of this process requires that the observed values in table 1 be substituted in the appropriate estimation equation from table 6 . For example, the equation for the two sets of $\mathrm{F}_{2}$ repulsion data is number 6 . When the observed values for the fourth set of data in table 1 are substituted, the estimation equation becomes

$$
293\left(\frac{2 p}{2+p^{2}}\right)+226\left(\frac{-2 p}{1-p^{2}}\right)+35\left(\frac{2}{p}\right)=0 .
$$

Similarly, the estimation equation for the first set of coupling-phase data is

$$
200\left[\frac{2(p-1)}{3-2 p+p^{2}}\right]+106\left[\frac{2(1-p)}{p(2-p)}\right]+30\left(\frac{2}{p-1}\right)=0 .
$$

This equation was obtained by substituting $1-p$ for $p$ in equation 6 and reversing the sign. All equations in table 6 and elsewhere are given for repulsion phase, and the substitution of $1-p$ for $p$ (accompanied by the sign change) must be made for all coupling data if both repulsion and coupling data are to be combined. If only the coupling phase is concerned, the repulsion-phase equations can be used and the answer subtracted from unity to obtain the $p$ value. Estimation equations for the seven other sets of data can be obtained in a similar manner from tables 1 and 6 .

The nine estimation equations should then be evaluated at $p=0.50$. This evaluation is easily accomplished with the scores in table 7 . The amount of information provided by each body of data is obtained by finding the mean amount of information contributed per individual at $p=0.50$, in table 8 , and multiplying by the number of individuals. The scores and $I_{\mathrm{p}}$ values for each of the nine sets of data are summarized in table 2 . The consistently negative values for the total scores indicate that the trial value of $p=0.50$ is too high.

The next trial value of $p$ can be obtained by Newton's method. In this method the deviation from zero of the first derivative (that is, the sum of the total scores) is divided by the second derivative $\left(I_{\mathrm{p}}\right)$ to estimate the correction to be made in $p$. Thus at $p=0.50$ the sum of all the remainders divided by the total information is found to be

$$
\frac{-649.778}{5826.488}=-0.112 \text {, }
$$


giving $0.50-0.11=0.39$ as a provisional estimate of $p$. Two additional applications of this process, as shown in table 2 , establish that $p$ slightly exceeds 0.40 . Accepting $p=0.40$ as sufficiently accurate, the standard error of this estimate is obtained by taking the square root of the inverse of the amount of information:

$$
s_{p}=\sqrt{\frac{1}{6807.455}}=0.012 .
$$

Thus, the recombination value is estimated as $40 \pm 1.2$ per cent.

Only one question remains to be answered: Are the data consistent in supporting this recombination value? Fisher (1949) has shown that the sum of the squares of the deviations from zero of the logarithm of the maximumlikelihood expression for each body of data, divided by the total amount of information provided by that body of data, is distributed as $x^{2}$. Thus,

$$
\chi^{2}=\sum_{1}^{N} \frac{D^{2}}{I}
$$

will provide a homogeneity test with $N-1$ degrees of freedom ( $N=$ number of sets of data pooled). Applied to the present example (see table 2),

$$
\chi^{2}=\frac{(-2.9449190)^{2}}{765.408}+\frac{(68.7393910)^{2}}{3319.046}+\cdots+\frac{(-10.5278834)^{2}}{59.983}=39.581 .
$$

Part of this value comes from the over-all deviation from expectancy resulting from the fact that $p$ was not estimated perfectly. This portion of the total $\chi^{2}$ can be estimated as $\frac{(16.6886852)^{2}}{6807.455}=0.041$. The remainder, 39.540, measures the homogeneity of the nine sets of data. This $\chi^{2}$ value has eight degrees of freedom and is obviously significant. The data therefore do not agree in supporting the hypothesis that the recombination value is 40 per cent.

Recombination values were then calculated for each set of data individually with the results shown in table 3 . All of the recombination values were lower than 0.50 , and with but two exceptions the deviations from independence were significant. The fact that the two loci are linked is therefore established beyond reasonable doubt. The data do not agree, however, in supporting the hypothesis that the recombination value is the same in the different tests. Most of the difficulty stems from three sets of data, numbers 4,5 , and 6 . The different recombination values observed in these cases could have been the result of seasonal influences upon recombination values, differences among the parental strains used, different recombination values in the sexes, or a combination of these factors. For purposes of prediction, the recombination fraction of $p=0.40$ appears to be the most appropriate, but defections from this value in certain seasons or with some parental combinations must be recognized as a possibility.

It will have been noticed that the maximum number of significant figures provided by tables 7 and 8 was carried in this example. This was done to avoid any possible confusion in extracting values from the tables. The inves- 
tigator can determine the appropriate number of significant figures for any particular case from the formulas given as footnotes to these tables. The number of significant figures in tables 7 and 8 was selected to provide at least 3-figure accuracy in final recombination values and standard errors for most data likely to be encountered. They provide less accuracy under some circumstances, particularly when the number of scores combined is large or when information values are small.

This example illustrates the use of $(a)$ scores for solving maximum-likelihood equations, (b) tables of $i_{\mathrm{p}}$ values for calculating standard errors, and (c) heterogeneity tests when several sorts of data are combined. An ancillary use of the $i_{\mathrm{p}}$ tables is in the planning of linkage experiments. Their use in predicting the value of various sorts of data for the estimation of linkage is discussed in the following section.

\section{PLANNING LINKAGE EXPERIMENTS}

\section{Linkage Estimates from Backcross and $F_{2}$ Data}

The amount of information about the recombination fraction provided by any set of data depends upon two factors: the completeness of the classification and the closeness of the linkage. No type of progeny segregating for two pertinent genes gives more information per individual than an $\mathrm{F}_{2}$ completely classified into the 10 possible genotypes. For this reason complete classification will be used here as a standard for comparing the value of different sorts of data, even though complete classification can only rarely be achieved without progeny tests.

With complete classification the amount of information per individual varies strikingly with changes in the magnitude of $p$. At $p=0.50$ each individual contributes 8 units of information about $p$ (table 8 ). Amounts of information per individual gradually increase as $p$ becomes smaller until at $p=0.01$ each individual contributes more than 200 units of information about $p$, or more than 25 times more information than is obtained with independence. These absolute amounts of information should be borne in mind in comparing data from complete classification with other types of data.

The magnitude of $i_{\mathrm{p}}$ in the usual backcross, that is, the backcross in which four classes are recognizable, is exactly one half that of complete classification. This is easily understandable since the value of $p$ in the $\mathrm{F}_{2}$ is influenced by crossing-over in both sexes. This does not mean that $\mathrm{F}_{2}$ data are more useful than backcross data. Backcrosses allow the separate estimation of crossing-over in both sexes. Hence they are almost always to be preferred to $\mathrm{F}_{2}$ 's if they can be obtained with reasonable economy, since with $\mathrm{F}_{2}$ data crossing-over must be assumed to be equal in both sexes.

With certain types of interallelic interaction, for example, with complementary genes, only two classes appear in the backcross of the double heterozygote to the double recessive. When the expected ratio is $1+p: 1-p$, that is, $3: 1$ when $p=0.50$, backcrosses provide only one fourth as much information per individual as complete classification (table 8). It is apparent from this table that such backcrosses in close repulsion are virtually valueless in the measurement of linkage.

The previous case illustrates the fact that a reduction in the number of 


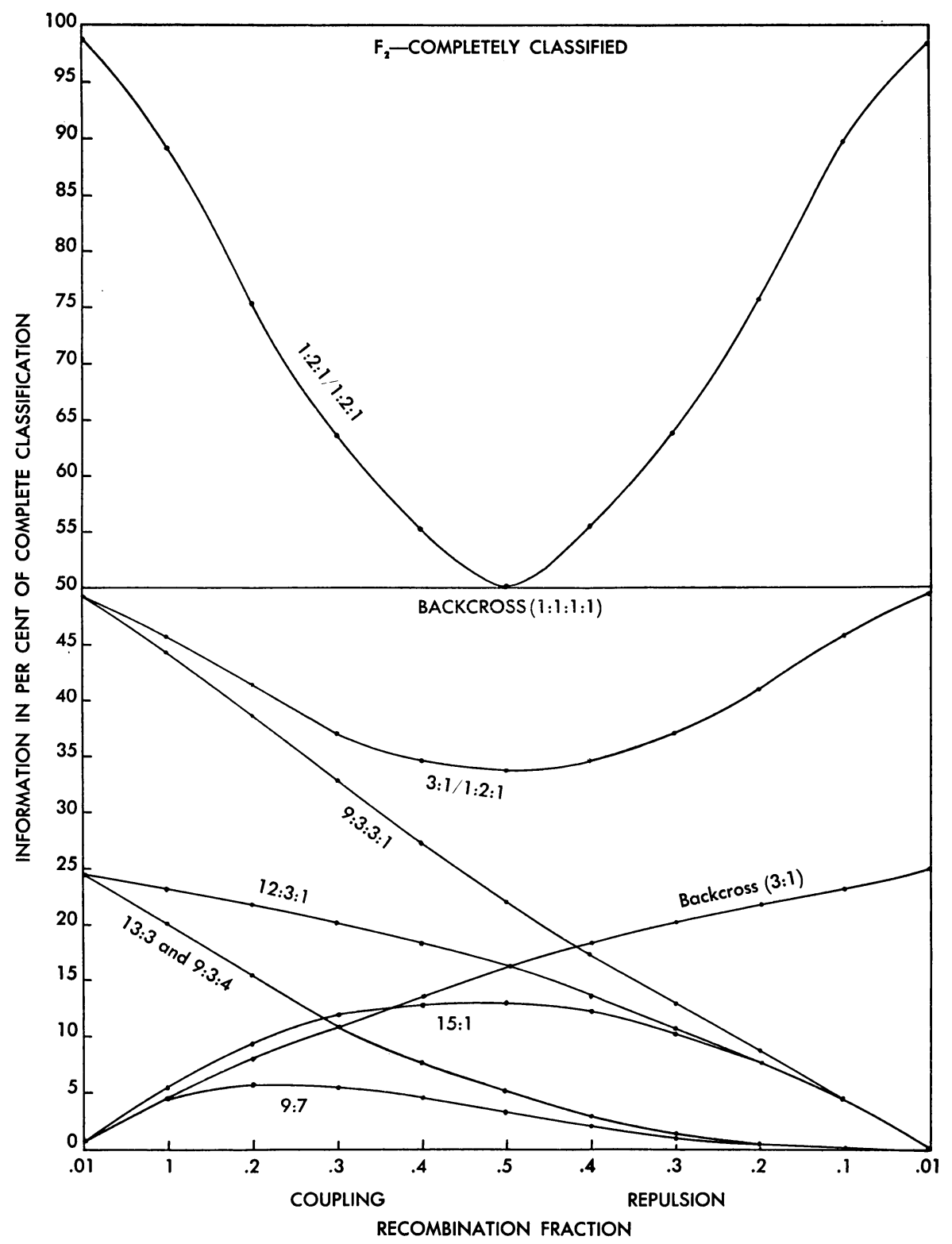


recognizable classes in backcrosses is accompanied by a reduction in the amount of information and that the loss is dependent upon the linkage intensity. This situation also prevails in $\mathrm{F}_{2}$ where the losses resulting from incomplete classification may be severe. The value of $i_{\mathrm{p}}$ for a number of the common $\mathrm{F}_{2}$ ratios is given in table 8. The comparative efficiency of various sorts of data is probably most readily visualized in a diagram such as figure 1 in which various sorts of backeross and $\mathrm{F}_{2}$ data are compared with complete classification as a standard. In general, the losses of information caused by incomplete classification are greatest in repulsion. This fact should be kept in mind in planning linkage experiments.

It should also be kept in mind that figure 1 compares the relative efficiency of various sorts of progenies with complete classification. Usually the investigator has no choice in the type of progeny he must use, and his primary interest resides in the practicality of estimating linkage from the sort of data he has or can obtain conveniently. Given the approximate cross-over value, table 8 makes it possible to estimate rapidly the size of population required for a given degree of accuracy. Thus, if dominance is complete at both loci, the cross is one of repulsion, $p$ is believed to be approximately 0.05 , and a standard error not larger than 5 per cent is required, $n=\left(i_{\mathrm{p}} \sigma^{2}\right)^{-1}=$ $\left[(1.006)(0.05)^{2}\right]^{-1}=398$.

This is a reasonable population size in most plant species. However, if all of the above postulates apply except that linkage between complementary genes is to be measured, $n$ becomes 133,000 , an impractically large number. If efficiency were not considered in advance in this latter case, a fairly standard population of 500 plants would provide a standard error of 82 per cent, indicating clearly that the estimate of $p$ obtained would be meaningless.

\section{The Use of Progeny Tests}

In the previous section it was established that the loss of information resulting from incomplete classification in the $\mathrm{F}_{2}$ can be very large. In some instances the losses due to this cause can be so large as to make the $\mathrm{F}_{2}$ virtually valueless in the measurement of linkage. This being the case, progeny tests of $\mathrm{F}_{2}$ individuals might prove more fruitful than raising additional $\mathrm{F}_{2}$ 's. In the following sections the relative value of $\mathrm{F}_{2}$ and $\mathrm{F}_{3}$ data is considered for the more common genetic situations. It should be emphasized that all calculations are based on the assumption of easy recognition of the various phenotypes in $\mathrm{F}_{2}$. This is frequently not the case, as for example when one or both of the gene pairs governs disease resistance. Here classification of single $\mathrm{F}_{2}$ plants is frequently difficult, but if $\mathrm{F}_{3}$ families are grown, the genotype of $\mathrm{F}_{2}$ plants can often be identified with assurance. Under such circumstances progeny tests are comparatively more valuable than indicated in the calculations to follow. A graphic comparison of the efficiency of various types of data is provided in figure 2.

The case of incomplete dominance. With both gene pairs expressing incomplete dominance, progeny tests provide two sorts of information, that obtained from completing, partially or completely, the $\mathrm{F}_{2}$ classification, that is, separating $\mathrm{AB} / \mathrm{ab}$ from $\mathrm{Ab} / \mathrm{aB}$, and that resulting from the fact that each $\mathrm{F}_{3}$ progeny is equivalent to an $\mathrm{F}_{2}$. Each family identified as to linkage 


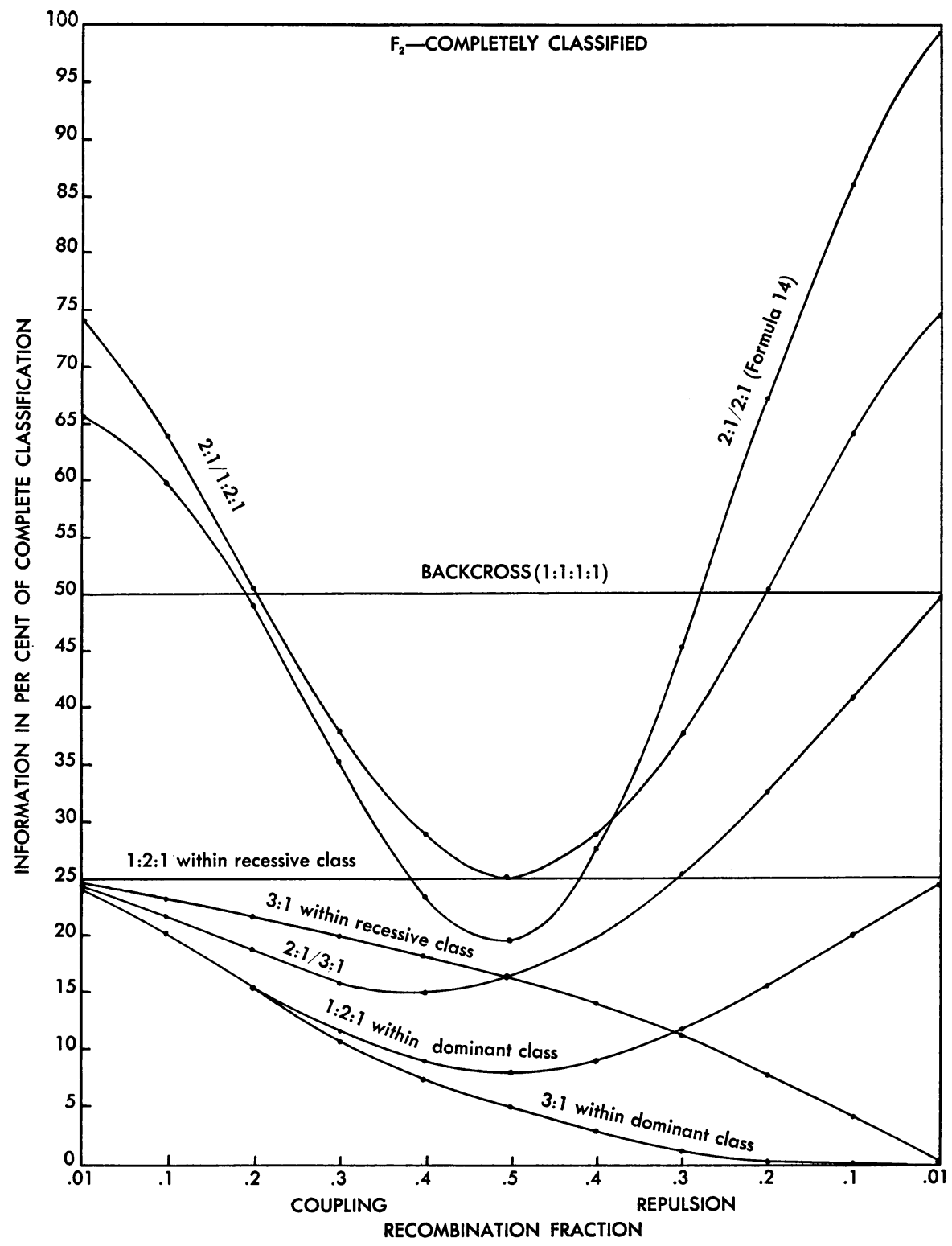


phase contributes $4 /\left(1-2 p+2 p^{2}\right)^{2}$ units of information about $p$ in connection with the separation of $\mathrm{AB} / \mathrm{ab}$ from $\mathrm{Ab} / \mathrm{aB}$ and, in addition, $\mathrm{F}_{2}$ type of information from either coupling or repulsion phase. These three sorts of data can, of course, be combined with the original $\mathrm{F}_{2}$ data to find the recombination value providing the best over-all fit.

In general outline, the procedure to be followed requires the estimation of $p$ for each family in order to separate coupling and repulsion progenies. The values of $p$ thus calculated would be expected to be normally distributed about the true value of $p$. It is possible, however, to determine the number of progeny that will serve to differentiate the repulsion and coupling cases at any prescribed level of probability. Achieving accurate classification in 99 out of 100 cases would appear to be satisfactory in most linkage investigations. Hence this level of probability will be used here and subsequently in connection with progeny tests.

The number of individuals required per family to assign it unambiguously $(P=0.99)$ to one or the other linkage phase is given by

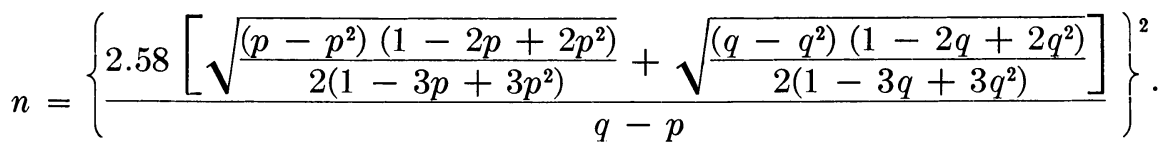

This method was first proposed by Immer (1934) for the solution of some similar problems. The number of plants required per progeny turns out to be 22 at $p=0.30$ and 89 at $p=0.40$.

The advantage of progeny tests over raising additional $\mathrm{F}_{2}$ individuals rests entirely with the additional information gained from completing the classification. Hence, if large families must be grown, comparatively few can be raised, and little information will be gained by completing the classification. Also, certain families may be misclassified as to their origin from coupling or repulsion $\mathrm{F}_{2}$ individuals, with the result that use of the $\mathrm{F}_{2}$ type of data can lead to error. In view of these factors, it would not seem desirable to attempt progeny tests at values of $p$ much larger than 0.30 . At lower values of $p$ they are more useful than raising additional $\mathrm{F}_{2}$ individuals.

The problem discussed here is largely academic because of the rarity of cases involving incomplete dominance for both gene pairs and also because the great efficiency of such data in $\mathrm{F}_{2}$ will usually provide a small standard error without recourse to progeny tests. It has been discussed because it introduces the subject of progeny tests in an uncomplicated fashion.

Incomplete dominance of one gene pair. When one of the gene pairs is dominant and the other incompletely dominant, there are three phenotypic classes that include more than a single genotype, namely, $\mathrm{A} \_\mathrm{BB}, \mathrm{A} \_\mathrm{Bb}$, and A_bb. Of these classes the first and third provide information about linkage only in connection with the completion of the classification of the $\mathrm{F}_{2}$. This being the case, progeny tests have only to distinguish between the genotypes $\mathrm{AA}$ and Aa. Misclassification can occur only if the progeny of $\mathrm{Aa} \mathrm{F}_{2}$ plants fail to include a recessive individual. Assurance against this $(P=0.99)$ will be obtained if each progeny contains at least 16 plants. $^{3}$

${ }^{3}$ The number of individuals, $n$, required for a given type to occur at least once with a probability $P$ is given by $n=\frac{\log (1-P)}{\log (1-X)}$, where $X$ is the fraction of the progeny expected to be of the type in question. 
The amount of information $\left(i_{p}\right)$ obtained from each A_bb progeny classified is given by $2 / p(1-p)(1+p)^{2}$ and from each A_bb progeny by $2 / p$ $(1-p)(2-p) .^{2}$ The information provided by a single $\mathrm{F}_{2}$ plant can be obtained from table 8 . Since each progeny requires that 16 plants be raised, the ratio of the two values $\left(i_{p} \mathrm{~F}_{3} / i_{p} \mathrm{~F}_{2}\right)$ must exceed 16 if progeny tests are to be profitable. Neither ratio approaches the required magnitude even in close repulsion where they reach their largest values. It may therefore be concluded that progeny tests of the A_BB and A_bb phenotypes have no place unless special circumstances are involved.

The remaining phenotype $\mathrm{A} \_\mathrm{Bb}$ includes three genotypes, $\mathrm{AB} / \mathrm{Ab}, \mathrm{AB} / \mathrm{ab}$, and $\mathrm{Ab} / \mathrm{aB}$. In progeny tests it is capable of providing two sorts of information, that obtained by completing the classification of the $\mathrm{F}_{2}$ and further $\mathrm{F}_{2}$ information supplied by the progeny of both coupling and repulsion doubly heterozygous $\mathrm{F}_{2}$ plants. Misclassification can result from two causes: failure of Aa heterozygotes to produce a recessive and inability to separate coupling from repulsion heterozygotes. Rearing 16 plants will provide an accuracy of $99 / 100$ as regards the first cause of difficulty. The size of progeny required to separate $A B / a b$ from $A b / a B$ can be determined by Immer's method. It turns out that 14 plants are required at $p=0.20$ and 46 plants at $p=0.30$. The first possible cause for misclassification thus dictates larger progenies than the second cause at values of $p \leqq 0.21$.

If progeny tests of the A_Bb phenotype are to be profitable, the amount of information obtained from each progeny classified, plus the additional $\mathrm{F}_{2}$ type of information from the segregation of $\mathrm{AB} / \mathrm{ab}$ and $\mathrm{Ab} / \mathrm{aB}$ plants, must exceed the information obtained from raising additional $\mathrm{F}_{2}$ 's, taking account of the fact that each $\mathrm{F}_{3}$ line need contain several individuals.

Each A_Bb individual classified contributes $1+2 p-2 p^{2} / p(1-p)(1-p+$ $\left.p^{2}\right)^{2}$ units of information. In addition, the doubly heterozygous families contribute $\mathrm{F}_{2}$ type of information. The amount of this information may be calculated as the product of the $i_{\mathrm{p}}$ value in table 8 multiplied by the expected frequency of the type of family, that is, $(1-p)^{2} / 2\left(1-p+p^{2}\right)$ and $p^{2} / 2(1-$ $p+p^{2}$ ) for coupling and repulsion respectively. The sum of these two sorts of information fails to reach a value 16 times as large as the value of $i_{\mathrm{p}}$ for the $\mathrm{F}_{2}$. Hence the progeny tests of the A_Bb phenotype are also not profitable under ordinary circumstances.

Both gene pairs completely dominant. Up to this point progeny tests, with one exception, have not been profitable as compared with the raising of additional $\mathrm{F}_{2}$ individuals. This is readily understood when it is realized: (a) that each $\mathrm{F}_{3}$ line must contribute at least 16 times as much information as an $\mathrm{F}_{2}$ individual, and $(b)$ that the $\mathrm{F}_{2}$ segregations considered to this point have been those giving comparatively large $i_{\mathrm{p}}$ values. When both gene pairs are completely dominant, the number of recognizable classes in $\mathrm{F}_{2}$ is reduced to four, with the result that $i_{\mathrm{p}}$ values are small, particularly in close repulsion. It might therefore be expected that progeny tests will be more valuable here than raising additional $\mathrm{F}_{2}$ individuals. There are three phenotypic classes that include more than one genotype-the two singly dominant classes A_bb and $a a B_{-}$and the doubly dominant class A_B_. Immer (1934) and Mather (1936) have considered progeny tests of both the singly and doubly dominant classes and have found that progeny tests are profitable for certain 
values of $p$. Mather's calculations were based upon raising large enough progenies for accurate identification in 999 cases out of 1,000. Immer proposed progenies of 25 plants, thus providing slightly greater accuracy of classification than Mather for singly dominant progenies but generally less accuracy for the doubly heterozygous progenies. The following calculations maintain the odds of 99:1 used elsewhere in this paper.

Consideration will be given first to the two singly dominant classes, which are equally useful in estimating linkage. Using the methods of the previous section, the calculations reveal that $\mathrm{F}_{3}$ progenies of 16 plants provide more information than $\mathrm{F}_{2}$ 's when $p<0.11$ in repulsion. When the accuracy is increased to 0.999 , requiring 24 plants per progeny, progeny testing is profitable up to $p=0.08$ (Mather, 1936).

Progen $y$ tests of doubly dominant $\mathrm{F}_{2}$ plants can provide both information from completing the classification of the original $\mathrm{F}_{2}$ and the $\mathrm{F}_{2}$ type of information yielded by the double heterozygotes. Only the former type of information is obtained where it is desired or possible to classify doubly dominant individuals into homozygotes, single heterozygotes, and double heterozygotes, ignoring the separation of double heterozygotes as to linkage phase. The amount of information thus obtained per line in close repulsion is practically identical to that obtained from singly dominant lines (table 8 , formulas 12 and 14). However, classification is slightly more difficult with the doubly dominant progenies, requiring 18 plants per progeny to assure $(P=0.99)$ detection of segregation for both gene pairs in double heterozygotes. Hence, of these two types of progeny tests, the one with singly dominant $\mathrm{F}_{2}$ individuals is preferred.

If the double heterozygotes are identified as to linkage phase, the completeness of the classification of the original $\mathrm{F}_{2}$ is increased (compare formulas 13 and 14), and the $\mathrm{F}_{2}$ type of information from the double heterozygotes also becomes available. Hence this separation will make possible a more efficient progeny test than the previous types if it can be accomplished with progenies of reasonable size. The minimum number of progeny must first of all be sufficiently large so that no more than one family per 100 will fail to show segregation for both gene pairs. This requires 18 individuals per progeny. Secondly, progeny sizes must permit separation of double heterozygotes into the $\mathrm{AB} / \mathrm{ab}$ and $\mathrm{Ab} / \mathrm{aB}$ genotypes. This requires 18 plants at $p=0.10,37$ plants at $p=0.20$, and 89 plants at $p=0.30$. Up to $p=0.10$ the number of plants per progeny is determined by the first consideration and need be only 18. With looser linkage the second requirement becomes the more stringent, and the number of plants per progeny must be increased accordingly. The maximum value of $p$ for which progeny tests are profitable is the point at which the ratio of the $\mathrm{F}_{3}$ to $\mathrm{F}_{2}$ information is equal to the number of plants required for accurate classification. This occurs between $p=0.13$ and 0.14 .

The policy with regard to the use of $\mathrm{F}_{3}$ families may be summarized as follows. Doubly dominant $\mathrm{F}_{3}$ families completely classified are the preferred source of information. They can be grown more profitably than additional $\mathrm{F}_{2}$ individuals up to $p=0.14$ in repulsion. Singly dominant families are to be preferred to doubly dominant ones classified only into homozygotes and single and double heterozygotes, since they provide nearly as much information per family and there is less chance for error in the classification of the single 
dominants. At values larger than $p=0.11$ in repulsion additional $\mathrm{F}_{2}$ individuals are more efficient than either of these latter two progeny tests unless special circumstances are involved.

Burnham and Kramer (1947) have given a numerical example of the combination of $\mathrm{F}_{2}$ and $\mathrm{F}_{3}$ data of this type in the estimation of linkage.

Progeny tests from the 9:6:1 $\mathrm{F}_{2}$ ratio. This case is identical to the previous one and provides one example where less complete classification does not lead to a loss of information.

Progeny tests from the 12:3:1 $\mathrm{F}_{2}$ ratio. Here only one of the singly dominant phenotypes, $a_{-} B_{-}$, is useful in estimating linkage. This phenotype includes two genotypes, $\mathrm{aB} / \mathrm{aB}$ and $\mathrm{aB} / \mathrm{ab}$, whose separation depends only upon the appearance of at least one aabb individual in progenies derived from $\mathrm{aaBb}$. As seen earlier, this can be accomplished 99 times in 100 if each progeny contains 16 individuals. Since each progeny provides $2 / p(1+p)\left(1-p^{2}\right)$ units of information and each $\mathrm{F}_{2}$ individual $1 / 1-p^{2}$ units of information, progeny tests will be profitable when the ratio of the former to the latter expression exceeds 16. The ratio is very large with tight linkage in repulsion, so progeny tests are very much worthwhile under those circumstances. At $p=0.11$ in repulsion, $\mathrm{F}_{2}$ and $\mathrm{F}_{3}$ data become equally valuable. Progeny tests will not ordinarily be advantageous if $p$ exceeds 0.11 .

Progeny tests of $\mathrm{F}_{2}$ plants phenotypically $\mathrm{AB}$ present difficulties in identifying one or more genotypes regardless of the value of $p$. With very tight linkage in repulsion (up to $p \approx 0.05$ ) fairly certain classification of the $\mathrm{F}_{3}$ progenies into one homozygous and two heterozygous classes is possible with small progenies. However, each of these progenies gives less information than may be had from progenies derived from aaB_- plants. With looser linkage, the progeny sizes required for the identification of several of the genotypes become large, and the information per progeny is not greatly different from that obtained from progeny tests of the single heterozygote. Therefore, only under most unusual circumstances should progeny tests of $\mathrm{AB}$ plants be attempted.

Progeny tests from the 9:3:4 ratio. Only two of the $\mathrm{F}_{2}$ phenotypes, $\mathrm{A}_{-} \mathrm{B}_{-}$ and $\mathrm{aaB}_{-}$, supply information on linkage. The situation with respect to the $\mathrm{aB}$ phenotype is exactly parallel to the case of this phenotype in the 12:3:1 ratio. Since, however, the $\mathrm{F}_{2}$ is less efficient in the present situation, it might be expected that progeny testing would be profitable over a wider range of $p$ values. It turns out that the threshold value of $p$ is 0.40 . Hence, progeny tests of the aaB_-phenotype are at least equally valuable with the $\mathrm{F}_{2}$ on a plant-to-plant basis up to this comparatively high $p$ value. At low values of $p$ the progeny tests are tremendously more efficient than the $\mathrm{F}_{2}$.

The A_B_ phenotype contains five genotypes and hence is capable of providing considerable information about linkage with complete classification. First, consider the separation of the double heterozygotes as to linkage phase. The number of plants required for this separation will be $(P=0.99)$ :

$$
n=\left[\frac{2.58\left(\sqrt{\frac{\left(1-p^{2}\right)\left(2+p^{2}\right)}{3 p^{2}}}+\sqrt{\frac{\left(1-q^{2}\right)\left(2+q^{2}\right)}{3 q^{2}}}\right)}{q-p}\right]^{2} .
$$


This function of $p$ reaches a minimum at $p=0.21$ so that larger numbers of plants are required at higher or lower values of $p$. Since 411 plants are required at $p=0.21$, the futility of attempting this separation is obvious.

While inability to separate the double heterozygotes as to linkage phase lessens the attractiveness of progeny tests of the A_B_ phenotype, it does not eliminate such progeny tests from consideration. Unfortunately, the genotypes $\mathrm{AB} / \mathrm{ab}$ and $\mathrm{AB} / \mathrm{Ab}$ are also separated with difficulty. The $\mathrm{AB} / \mathrm{ab}$

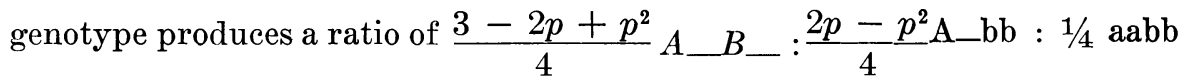

so that $\mathrm{A} \_\mathrm{bb}$ individuals are quite infrequent if $p$ is small. If the $\mathrm{AB} / \mathrm{ab}$ genotype is to be separated from $\mathrm{AB} / \mathrm{Ab}$, sufficiently large progenies must be grown to guarantee with reasonable probability the occurrence of at least one Abb individual. Such individuals make up 16 per cent of each family at $p=0.40,12.75$ per cent at $p=0.30,9$ per cent at $p=0.20$, and 4.75 per cent at $p=0.10$. Thus, if the appearance of at least one A_bb individual is to be assured in the progeny of each double heterozygote, $26,34,40$, and 95 individuals, respectively, are required per family as $p$ varies from 0.40 to 0.30 to 0.20 and to 0.10 . The usefulness of this type of progeny test will therefore depend upon the amount of information it gives relative to the $\mathrm{F}_{2}$ and to progeny tests of the aaB_- phenotype.

Regardless of the value of $p$, progeny tests of singly vs. doubly dominant individuals are not strikingly different in the amounts of information they give. The double dominant gives slightly more information than the single dominant from $p=0.00$ to $p=0.18$, and from $p=0.69$ to $p=0.99$. The reverse is true for the remaining values of $p$. Thus, in the range of $p=0.00$ to $p=0.18$ in repulsion the singly dominant phenotype is the best source of linkage information because it gives very nearly as much information per progeny as the double dominant, and it ean be classified into genotypes with smaller populations. From $p=0.18$ to $p=0.40$ the single dominants are even more advantageous because, in addition to the advantage of easier classification, the $i_{\mathrm{p}}$ values are larger. When $p>0.40$ the $\mathrm{F}_{2}$ provides more information per plant than progeny tests and is therefore to be recommended. These results therefore indicate that progeny tests of doubly dominant individuals have no place in the measurement of linkage from the 9:3:4 ratio. These conclusions are different from those of Immer (1934).

Progeny tests from the 13:3 $\mathrm{F}_{2}$ ratio. Because of the low efficiency of this segregation throughout most of its range (table 8 ), $\mathrm{F}_{3}$ progeny tests might be expected to be useful. For each progeny phenotypically aaB separated into the genotypes $\mathrm{aB} / \mathrm{aB}$ and $\mathrm{aB} / \mathrm{ab}, 2 / p(1+p)\left(1-p^{2}\right)$ units of information are obtained contrasted to $4 p^{2} /\left(3+p^{2}\right)\left(1-p^{2}\right)$ units per $\mathrm{F}_{2}$ individual. The separation of $\mathrm{aB} / \mathrm{aB}$ and $\mathrm{aB} / \mathrm{ab}$ can be made with 16 individuals. Progeny tests are therefore extremely valuable in close repulsion, become equally valuable with the $\mathrm{F}_{2}$ on a plant-for-plant basis at $p=0.41$, and provide less information per plant at higher values of $p$.

Progeny tests of the A_ (or ab) phenotype are complicated by difficulties of classification. In the first place, separation of the double heterozygotes as to linkage phase requires impractically large populations. Second, the $A B / a b$ 
genotype is difficult to separate from homozygous $\mathrm{AB} / \mathrm{AB}$ at low $p$ values, since the former produces only $\frac{p(2-p)}{4}$ aaB_ individuals. Two dispositions of this genotype are possible: $(a)$ with low values of $p$ it could be included with lines homozygous for the A_phenotype; $(b)$ with looser linkage it could be included with those genotypes producing $3 \mathrm{~A}_{-}: 1 \mathrm{aB}$. Under situation $(a)$ the estimation equation is

$$
\begin{gathered}
\frac{d L}{d p}=(e+f+h+j+k+n)\left(\frac{2}{1+p}\right)+(g+i)\left(\frac{-1}{1-p}\right) \\
+m\left(\frac{1-2 p}{p(1-p)}\right)+l\left(\frac{-2}{1-p}\right)=0,
\end{gathered}
$$

and the amount of information per family classified is

$$
i_{p}=\frac{p+1}{2 p(1-p)}
$$

In situation $(b)$ the estimation equation is

$$
\begin{aligned}
\frac{d L}{d p}=(e+f+ & j+h+n)\left(\frac{2-2 p}{1+2 p-p^{2}}\right)+(g+h+i)\left(\frac{2 p-1}{1-p+p^{2}}\right) \\
+ & m\left(\frac{1-2 p}{p-p^{2}}\right)+l\left(\frac{-2}{1-p}\right)=0,
\end{aligned}
$$

and the $i_{\mathrm{p}}$ value is given by

$$
1+\frac{(1-p)^{2}}{1+2 p-p^{2}}+\frac{(1-2 p)^{2}}{2\left(1-p+p^{2}\right)}+\frac{(1-2 p)^{2}}{2 p(1-p)} .
$$

Progeny tests from the 15:1 $\mathrm{F}_{2}$ ratio. The ratio (A_: ab) occurring within $\mathrm{F}_{3}$ progenies will be one of the following four types: $1: 0,3: 1,3+2 p-p^{2}: 1-$ $2 p+2 p^{2}$, or $4-p^{2}: p^{2}$. The first two categories are, of course, easily distinguished from one another, only 16 plants being required per progeny. However, separating the final two segregations, which result from the coupling and repulsion double heterozygotes respectively, from each other and from the other types is more difficult. Because of the low efficiency of the $\mathrm{F}_{2}$ type of data and the correspondingly high standard errors, separation of $\mathrm{AB} / \mathrm{ab}$ and $\mathrm{Ab} / \mathrm{aB}$ as to linkage phase is impractical regardless of the value of $p$. Also the repulsion-phase double heterozygote produces only 6.25 per cent of ab phenotypes at $p=0.50$ and even fewer with lower values of $p$. It therefore appears hopeless to attempt to separate this segregation from the 1:0 type since 71 individuals per family would be required with independence and greater numbers with linkage. At $p=0.50$ these families could be distinguished 19 times out of 20 from families segregating 3:1 with progenies of 35 individuals, although 82 per family would be required if the probability is set at 0.99 . The numbers required become increasingly smaller with closer 
linkage. With close linkage there appears to be little likelihood for misclassification if the $\frac{\mathrm{Ab}}{\mathrm{aB}}$ genotype is classified with 1:0 families, that is, families homozygous for the A_ phenotype.

The classification of the coupling double heterozygote is also troublesome in that the expected number of ab individuals changes from 25 per cent to 6.25 per cent as $p$ changes from 0.00 to 0.50 . With close linkage these double heterozygotes can probably be included with the single dominants without danger of confusion.

The following procedures can therefore be recommended for progeny tests. The identification of only three types of families should be attempted. With tight linkage, the estimation equation is

$$
\begin{aligned}
\frac{d L}{d p}=(e+f+ & g+j+l+i) \frac{2}{p-2} \\
+ & (k+m+h)\left[\frac{2(1-p)}{p(2-p)}\right]+n\left(\frac{2}{p}\right)=0,
\end{aligned}
$$

and each family provides $\frac{2(1-3 p)}{p(2-p)^{2}}$ units of information. If the minimal family size is arbitrarily set at 35 individuals, such progeny tests are profitable compared with the $\mathrm{F}_{2}$ at $p$ values up to 0.03 in repulsion.

If the linkage is loose, not only the coupling but repulsion double heterozygotes should be classified with $3: 1$ families. The estimation equation then becomes

$$
\frac{d L}{d p}=(e+f+g+j+l)\left(\frac{2 p}{2-p^{2}}\right)+n\left(\frac{-2}{p}\right)=0
$$

and each family provides $2 / 2-p^{2}$ units of information. This sort of progeny test would, of course, be useful only if classification on a single-plant basis is difficult and progeny tests are essential for the identification of genotypes.

Progeny tests with complementary genes. Since this $\mathrm{F}_{2}$ has the lowest efficiency of any commonly encountered, it might be surmised that progeny tests would be extremely valuable here. The single dominants obviously provide no information about linkage, so progeny tests are necessarily confined to the $\mathrm{AB}$ phenotype. In this phenotype are included genotypes producing one of the following four ratios $(\mathrm{AB}: \mathrm{Ab}, \mathrm{aB}$, or $\mathrm{ab}): 1: 0,3: 1,3-2 p+\mathrm{p}^{2}$ : $1+2 p-p^{2}$, or $2+p^{2}: 2-p^{2}$.

Separating the first two eategories is easy. However, much difficulty is associated with the separation of the coupling and repulsion double heterozygotes from each other and from the first two groups. The same procedure used previously shows that it is idle to contemplate separating double heterozygotes as to linkage phase, the progeny sizes required being very large. Difficulty is also encountered in separating the second and third ratios. The ratio $3-2 p+p^{2}: 1+2 p-p^{2}$ has a value of $9: 7$ when $p=0.50$. Such progenies must contain at least 133 individuals if they are to be distinguished from the 3:1 ratio. With linkage, larger progenies are needed. In the fourth category the ratio changes from 9:7 to $1: 1$ as $p$ changes from 0.50 to 0.00 . 
To distinguish between $3: 1$ and 1:1 ratios requires 113 plants. In other words, the only separation easily made is into homozygous lines vs. segregating lines. The appropriate estimation equation is therefore

$$
\frac{d L}{d p}=e\left(\frac{2}{p}\right)-(e+f+g+h+i)\left(\frac{2 p}{2+p^{2}}\right)=0 .
$$

This separation provides $\frac{4\left(1+2 p^{2}\right)}{\left(2+p^{2}\right)^{3}}$ units of information per family, and since it can be made with 16 plants, progeny tests will be useful so long as the ratio

$$
\frac{4\left(1+2 p^{2}\right)}{\left(2+p^{2}\right)^{3}}: \frac{4 p^{2}}{\left(2+p^{2}\right)\left(2-p^{2}\right)}
$$

exceeds 16. Therefore, progeny tests are useful over the range $p=0.00$ to $p=0.18$.

\section{Estimating Linkage from Incomplete $\mathrm{F}_{2}$ Ratios}

In the segregations considered up to this point, the assumption was made that all of the genotypes were viable. In practice, $\mathrm{F}_{2}$ ratios are frequently encountered in which certain genotypes are either inviable or effectively inviable in that they cannot be accurately classified, or for some practical reason are difficult to handle. Several ratios of this type will now be considered from the standpoint of their value in the measurement of linkage.

In one of the more common of these situations linkage is measured from the ratio produced within one of the recessive classes. Seed-coat color and indeterminate habit of growth (vine) in lima beans are an example. Vine individuals (D_) of certain hybrids mature so late that they usually fail to set seeds in the field. This, coupled with their large space requirement, makes it more efficient to rogue them as soon as they can be recognized early in growth and to classify only bush plants for seed-coat color. This procedure will be recognized as equivalent for the purpose of estimating linkage to the 12:3:1 ratio (equation 7 ). This type of progeny is quite efficient with close coupling and reasonably efficient in the repulsion range (table 8 and figure 2). If the heterozygote can be identified because of incomplete dominance, that is, the $\mathrm{aB} / \mathrm{aB}, \mathrm{aB} / \mathrm{ab}$, and $\mathrm{ab} / \mathrm{ab}$ genotypes are all recognizable, the efficiency is considerably increased in repulsion and also through nearly all of the coupling range. Thus, if dominance is complete, progeny tests to separate genotypes $\mathrm{aB} / \mathrm{aB}$ and $\mathrm{aB} / \mathrm{ab}$ may be justified. Since each $\mathrm{F}_{2}$ individual contributes $1 / 1-p^{2}$ units and each $\mathrm{F}_{3}$ line $1 / p(2-p)$ units of information, progeny tests will be profitable when $p<0.03$ in repulsion.

A parallel situation exists when linkage is measured from the segregation within one of the dominant classes. This procedure is equivalent to estimation from the 9:3:4 ratio and the appropriate equation is number 9 .

Three types of ratios encountered fairly frequently result from combinations of $\mathrm{F}_{2}$ and $\mathrm{F}_{3}$ data. The most common is the $3: 1 / 2: 1$, producing a ratio of $6: 3: 2: 1$ when $p=0.50$. This is an extension of the ratio of $3: 1$ within the dominant class, since it involves classification of the other gene 
pair into a 2:1 ratio. An example is provided by the classification into a $3: 1$ ratio in the field for an adult plant character followed by classification into a 2:1 ratio in the greenhouse for a seedling lethal. The estimation equation is number 18 .

If the heterozygotes are identified either as a result of incomplete dominance or progeny tests, the result is a $1: 2: 1$ ratio superimposed on a $2: 1$, or a ratio of $2: 4: 2: 1: 2: 1$ when $p=0.50$. The estimation equation is number 19 .

The third ratio of this type is the $2: 1 / 2: 1$. Although not common, this situation has been encountered when both recessives were so weak that survival was very poor under field conditions and a progeny test in the greenhouse was required for the measurement of linkage. This will be recognized as equivalent to testing A_B_ phenotypes in the 3:1/3:1 situation. The appropriate estimation equations are therefore numbers 13 or 14, depending upon circumstances.

Another type of case leading to a 2:1/2:1 ratio has been encountered by Dr. C. M. Rick with characters in tomatoes such as wooly (Wo) and Xantha (Xa). With either gene homozygous dominant individuals die, with the result that the $\mathrm{F}_{2}$ estimation equation takes the form

$$
\begin{gathered}
\frac{d L}{d p}=(h+i) \frac{2(2 p-1)}{1-2 p+2 p^{2}}+(k+m) \frac{1-2 p}{p(1-p)}+n\left(\frac{2}{p}\right) \\
-(h+i+k+m+n)\left(\frac{2 p}{2+p^{2}}\right)=0,
\end{gathered}
$$

and the $i_{p}$ value is

$$
\frac{1-3 p+p^{2}+4 p^{3}-2 p^{4}}{p(1-p)\left(1-2 p+2 p^{2}\right)}
$$

\section{Measurement of Linkage when a Gene is Linked with a Member of a Complementary or Duplicate Pair or a Pair Producing a 13:3 Ratio}

Hutchinson (1929) has considered the problem of estimating linkage values when one member of a complementary or duplicate pair is linked to a third gene pair. His results indicated that $\mathrm{F}_{2}$ data are very low in efficiency so that large populations are required to obtain reliable measurements of recombination values. The present extension is intended to point out some ways of increasing the efficiency of estimation.

In general, two procedures are available to the investigator confronted by data of this sort: he can raise the progenies to identify the double heterozygotes suitable for estimating linkage by equation 6 , or he can progenytest the $\mathrm{F}_{2}$ families available to him. Only the second case need be considered here. Symbols for observed and expected numbers in various distinguishable classes are given in table 5 . Estimation equations and $i_{\mathrm{p}}$ values are given in tables 6 and 8 respectively.

Linkage with a member of a complementary pair. It is apparent from table 8 and figure 3 that the $9: 7 / 3: 1 \mathrm{~F}_{2}$ segregation is quite uninformative about linkage, particularly in close repulsion. It can also be seen that the identification of AA and Aa greatly increases the amount of information 


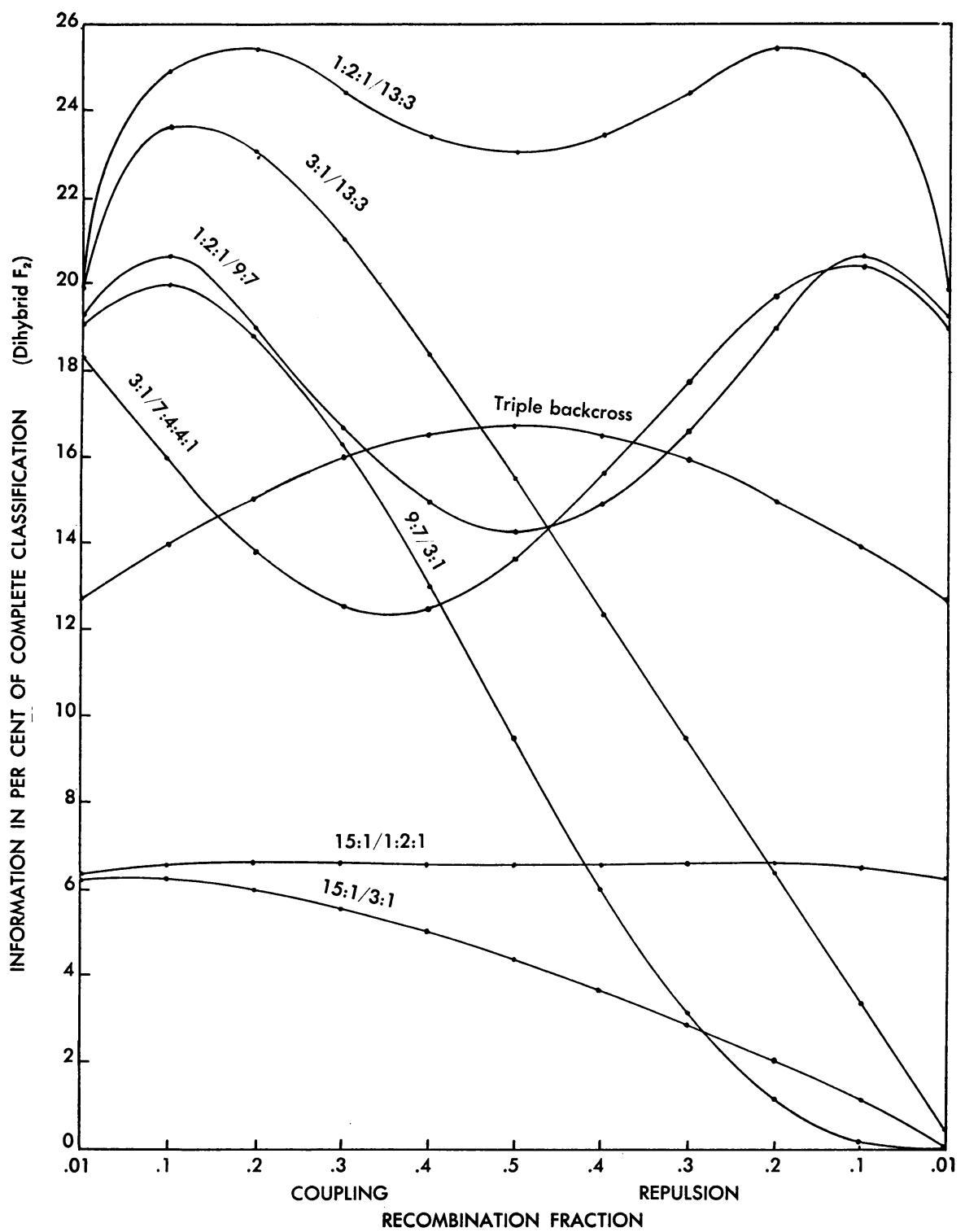


in the repulsion range. An investigation of the comparative efficiency of $\mathrm{F}_{2}$ and $\mathrm{F}_{3}$ shows that progeny tests will be profitable in the range $p=0.00$ to 0.21 in repulsion.

Linkage with a member of a duplicate pair. The 15:1/3:1 $\mathrm{F}_{2}$ segregation also contributes little information about linkage (table 8 and figure 3 ). Identification of $\mathrm{AA}$ and Aa leads to increases in the amount of information, particularly in close repulsion. By methods used previously it can be shown that this progeny test is profitable only in repulsion in the range $p=0.00$ to 0.03 .

Progeny tests also make it possible to separate individuals phenotypically B_C_ into two nonsegregating and two segregating classes, 3:1 and 15:1. This separation requires 82 individuals if the probability is set at 0.99 . From table 8 it is easily determined that this separation is profitable only in extremely tight repulsion. If the separation of $\mathrm{AA}$ and $\mathrm{Aa}$ is also made, 12 classes are identified and the amount of information is substantially increased. This separation requires only 16 individuals which may be in addition to the 82 individuals required for the above separations, if, for example, both a seedling and an adult plant character are involved. Compared to the 15:1/3:1 segregation in $\mathrm{F}_{2}$, this progeny test is profitable in repulsion up to $p=0.03$ or 0.04 , according to the requirement of 82 or 98 individuals per progeny.

Linkage with a gene pair producing a 13:3 ratio. The 13:3/3:1 segregation in $\mathrm{F}_{2}$ also has low efficiency in close repulsion. By methods used previously it can be shown that progeny tests to separate AA and Aa are profitable for the range $p=0.00-0.04$ in repulsion.

\section{SUMMARY}

In estimating recombination values in heredity, several types of genetic data are frequently available. For example, backeross, $\mathrm{F}_{2}$, and $\mathrm{F}_{3}$ data from both coupling and repulsion crosses might exist. When complex data are encountered, a single joint estimate of the recombination value which best fits all the data can be made with the method of maximum likelihood. Further, the homogeneity of the data can be examined with little additional computation. Estimation equations are given for various backcross, $\mathrm{F}_{2}$, and $\mathrm{F}_{3}$ situations, including equations for estimating linkage intensities between a member of a complementary or duplicate pair, or a gene pair producing a 13:3 ratio, and a third gene pair. Tables of scores to facilitate the numerical solution of these equations are included. Also provided are tables to facilitate the calculation of the standard errors of the recombination values.

Tremendous variations in the value of various sorts of genetic data for the estimation of recombination fractions make advance planning an important feature of linkage investigations. In this regard the value of different sorts of genetic data is examined for a variety of situations under the assumption that positive classification of single plants is possible. The results of this evaluation can easily be adapted to situations where classification of single plants is not positive and progeny tests are a necessary feature of inheritance studies, as for example in studies of the inheritance of resistance to many diseases. 


\section{ACKNOWLEDGMENT}

The author is indebted to Professor H. L. Alder for aid in some mathematical aspects of this paper and also for his critical review of the manuscript.

\section{LITERATURE CITED}

Allard, R. W.

1953a. Inheritance of some seed coat colors and patterns in lima beans. Hilgardia 22: $167-177$.

$1953 b$. Inheritance of four morphological characters in lima beans. Hilgardia $22: 383-$ 389.

Fisher, R. A.

1946. A system of scoring linkage data, with special reference to the pied factors in mice. Amer. Nat. $80: 568-578$.

1949. Statistical methods for research workers. 11th ed. xiv +354 p. Oliver and Boyd. Edinburgh and London.

Fisher, R.A., and BhaI BALMUKAND

1928. The estimation of linkage from the offspring of selfed heterozygotes. Jour. Genetics $20: 79-92$.

Hutchinson, J. B.

1929. The application of the "method of maximum likelihood" to the estimation of linkage. Genetics $14: 519-537$.

IMMER, F. R.

1930. Formulae and tables for calculating linkage intensities. Genetics 15:81-98.

1934. Calculating linkage intensities from $F_{3}$ data. Genetics $19: 119-136$.

IMMER, F. R., and M. T. HENDERSON

1943. Linkage studies in barley. Genetics $28: 419-440$.

Kramer, H. H., and C. R. BURnhaM

1947. Methods of combining linkage intensity values from backcross, $F_{2}$ and $F_{3}$ genetic data. Genetics $32: 379-390$.

MATHER, K.

1935. The combination of data. Ann. Eugenies 6:399-410.

1936. Types of linkage data and their value. Ann. Eugenics 7:251-264.

1951. The measurement of linkage in heredity. $2 \mathrm{~d}$ ed. $149 \mathrm{p}$. Methuen and Co., Ltd. London.

STEPHENS, W. L.

1939. Tables of the recombination fraction estimated from the product ratio. Jour. Genetics $39: 171-180$. 
TABLE 1

$F_{2}$ AND $F_{3}$ DATA FROM LIMA BEAN HYBRIDS SEGREGATING FOR THE GENE PAIRS Dd AND Rr

\begin{tabular}{|c|c|c|c|c|c|c|c|c|c|c|c|c|c|c|}
\hline \multirow{2}{*}{$\begin{array}{c}\text { Data } \\
\text { set } \\
\text { no. }\end{array}$} & \multirow{2}{*}{ Type of data } & \multicolumn{13}{|c|}{ Observed frequencies of phenotype and genotype* } \\
\hline & & $a$ & $b$ & $c$ & $d$ & $e$ & $f$ & $g$ & $h+i$ & $j$ & $k$ & $l$ & $m$ & $n$ \\
\hline 1 & $F_{2}$ coupling. & 200 & 57 & 49 & 30 & .. & .. & $\ldots$ & $\ldots$ & .. & $\ldots$ & $\ldots$ & .. & .. \\
\hline 2 & $\mathrm{~F}_{2}$ coupling... & 842 & 234 & 255 & 126 & . & .. & . & .. & . & . & . & .. & .. \\
\hline 3 & $\mathrm{~F}_{2}$ coupling. . & 274 & 71 & 64 & 45 & . & .. & . & .. & .. & $\ldots$ & .. & .. & .. \\
\hline 4 & $\mathrm{~F}_{2}$ repulsion.. & 293 & 107 & 119 & 35 & . & .. & . & . & . & $\ldots$ & .. & .. & .. \\
\hline 5 & $\mathrm{~F}_{2}$ repulsion ..... & 50 & 21 & 30 & 0 & $\ldots$ & .. & $\ldots$ & $\ldots$ & . & . & .. & .. & .. \\
\hline 6 & $1: 2: 1$ within re- & & & & & & & & & & & & & \\
\hline & cessive class.... & .. & .. & .. & .. & . & .. & . & .. & . & . & 8 & 28 & 36 \\
\hline 7 & $2: 1 / 1: 2: 1 \ldots \ldots$ & .. & .. & .. & .. & 7 & 13 & 14 & 31 & 2 & 10 & .. & .. & .. \\
\hline 8 & $3: 1 / 1: 2: 1 \ldots \ldots$ & .. & .. & .. & .. & 16 & .. & 43 & .. & 27 & . & 5 & 16 & 12 \\
\hline 9 & $1: 2: 1$ within & & & & & & & & & & & & & \\
\hline & dominant class & .. & . & .. & .. & 20 & .. & 46 & . & 11 & . & .. & . & .. \\
\hline
\end{tabular}

* See table 4 for significance of symbols.

TABLE 2

ESTIMATION OF THE RECOMBINATION VALUE FROM THE DATA OF TABLE 1 AND THE EXAMINATION FOR HETEROGENEITY, USING FISHER'S SCORING METHOD

\begin{tabular}{|c|c|c|c|c|c|c|c|c|}
\hline \multirow{2}{*}{$\begin{array}{c}\text { Data } \\
\text { set } \\
\text { no. }\end{array}$} & \multirow{2}{*}{$\begin{array}{c}\text { Estimation } \\
\text { equation } \\
\text { no. }\end{array}$} & \multicolumn{2}{|c|}{$p=0.50$} & \multicolumn{2}{|c|}{$p=0.39$} & \multicolumn{2}{|c|}{$p=0.40$} & \multirow[b]{2}{*}{$\chi^{2}$} \\
\hline & & \multicolumn{2}{|c|}{ Score Information } & Score & Information & Score & Information & \\
\hline $1 \ldots$ & 6 & -67.5555502 & 597.408 & 4.733272 & 786.912 & -2.9449190 & 765.408 & 0.011 \\
\hline $2 .$. & 6 & -226.2222011 & 2590.546 & $103.953846 \mathrm{C}$ & 3412.294 & 68.7393910 & 3319.046 & 1.424 \\
\hline $3 \ldots$ & 6 & -121.7777701 & 807.212 & -26.159604 & 1063.268 & -36.1970389 & 1034.212 & 1.267 \\
\hline $4 \ldots$ & 6 & -31.1111166 & 985.012 & 77.7792568 & 791.666 & 68.2804212 & 806.070 & 5.783 \\
\hline $5 \ldots$ & 6 & -45.7777783 & 179.578 & $-28.794074 \varepsilon$ & 144.329 & -30.0529110 & 146.955 & 6.146 \\
\hline $6 \ldots$ & 16 & -112.0000000 & 144.000 & -51.113912 & 151.344 & -56.6666664 & 149.976 & 21.411 \\
\hline $7 .$. & 19 & -20.0000000 & 154.000 & -4.498955 & 191.730 & -6.3461558 & 185.108 & 0.218 \\
\hline $8 \ldots$ & 5 & -13.3333337 & 317.373 & 26.421695 & 345.695 & 22.4044475 & 340.697 & 1.473 \\
\hline \multirow[t]{5}{*}{$9 \ldots \ldots \ldots$} & \multirow[t]{5}{*}{17} & -11.9999997 & 51.359 & -10.304661 & 61.908 & -10.5278834 & 59.983 & 1.848 \\
\hline & & \multirow{4}{*}{\multicolumn{2}{|c|}{$\begin{array}{l}-649.77774975826 .488 \\
\frac{-649.778}{5826.488}=-0.112 \\
p=0.50-0.11=0.39\end{array}$}} & \multirow{4}{*}{\multicolumn{2}{|c|}{$\begin{array}{l}92.01686236949 .146 \\
\frac{92.017}{6949.146}=0.0132 \\
p=0.39+0.01=0.40\end{array}$}} & \multirow{4}{*}{\multicolumn{2}{|c|}{$\begin{array}{c}16.68868526807 .455 \\
\frac{16.689}{6807.455}=0.0025 \\
p=0.400+0.0025=0.4025\end{array}$}} & 39.581 \\
\hline & & & & & & & & \\
\hline & & & & & & & & \\
\hline & & & & & & & & \\
\hline
\end{tabular}


TABLE 3

RECOMBINATION VALUES AND STANDARD ERRORS FOR THE NINE SETS OF

DATA OF TABLE 2

\begin{tabular}{|c|c|}
\hline Data set & $\begin{array}{l}\text { Recombination } \\
\text { value }(p), \\
\text { per cent }\end{array}$ \\
\hline $1 \ldots \ldots \ldots \ldots \ldots \ldots \ldots \ldots \ldots \ldots$ & $39 \pm 3.6$ \\
\hline $2 \ldots \ldots$ & $42 \pm 1.8$ \\
\hline $3 \ldots \ldots \ldots$ & $36 \pm 2.9$ \\
\hline $4 \ldots \ldots \ldots$ & $47 \pm 3.3$ \\
\hline $5 \ldots \ldots \ldots \ldots \ldots$ & $0.0 \pm 10.0$ \\
\hline $6 \ldots \ldots \ldots \ldots \ldots \ldots \ldots \ldots \ldots \ldots \ldots \ldots \ldots \ldots \ldots$ & $31 \pm 7.7$ \\
\hline $7 \ldots \ldots \ldots \ldots \ldots \ldots \ldots \ldots \ldots \ldots \ldots \ldots \ldots \ldots \ldots$ & $36 \pm 6.8$ \\
\hline $8 \ldots \ldots \ldots \ldots \ldots \ldots \ldots \ldots \ldots \ldots \ldots \ldots \ldots \ldots \ldots$ & $46 \pm 5.6$ \\
\hline $9 \ldots \ldots \ldots \ldots \ldots \ldots \ldots \ldots \ldots \ldots \ldots \ldots \ldots \ldots \ldots$ & $24 \pm 9.0$ \\
\hline
\end{tabular}

TABLE 4

SYMBOLS FOR OBSERVED AND EXPECTED FREQUENCIES OF VARIOUS GENOTYPES AND PHENOTYPES OCCURRING AMONG THE SELFED PROGENY OF AaBb INDIVIDUALS

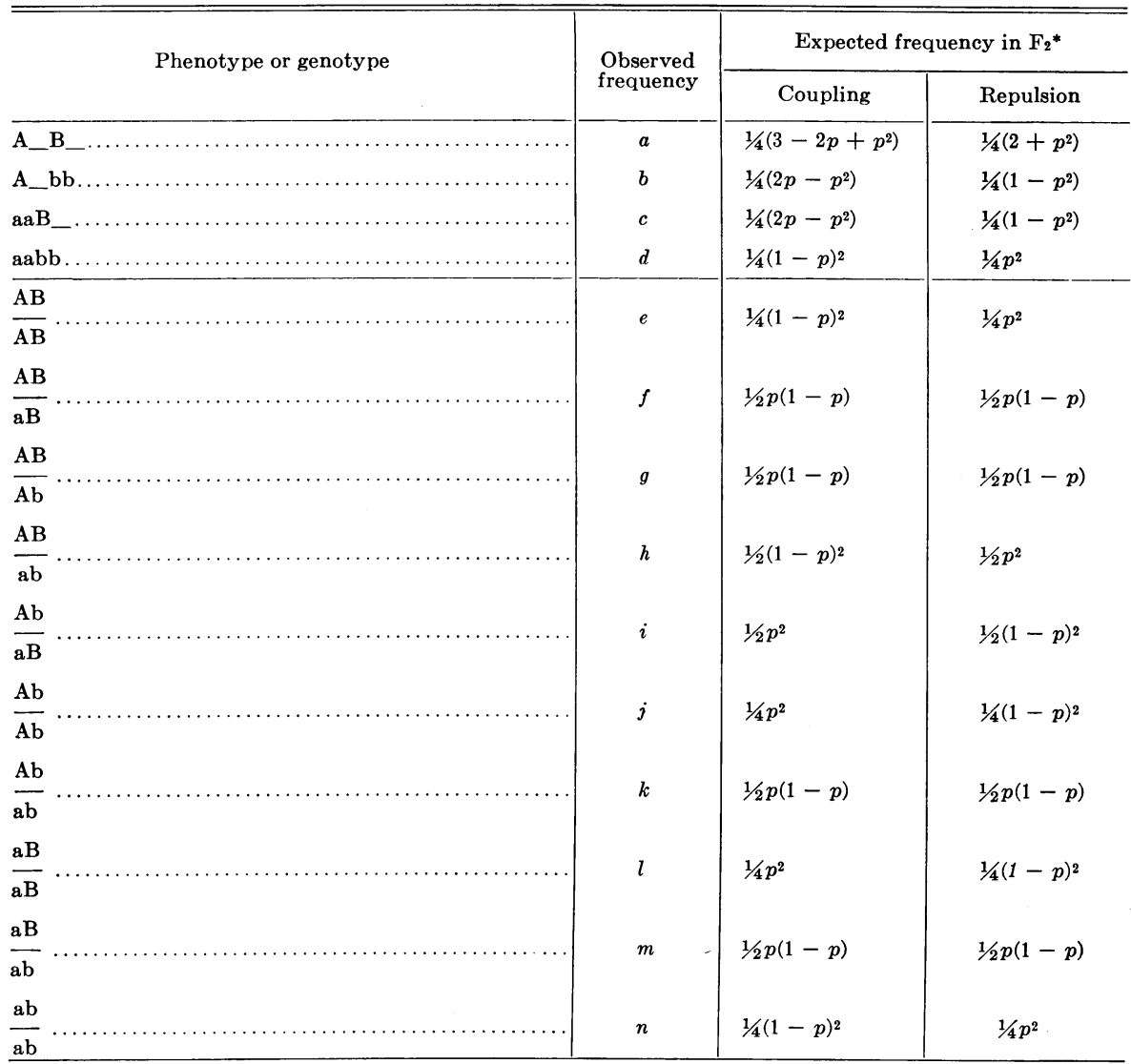

* Backcross repulsion phase expectanoies for the $\mathrm{AB}$ and $\mathrm{ab}$ and the $\mathrm{Ab}$ and $\mathrm{aB}$ phenotypes are $1 / 2 p$ and $1 / 2(1-p)$ respectively. 
TABLE 5

SYMBOLS FOR OBSERVED AND EXPECTED FREQUENCIES OF VARIOUS GENOTYPES AND PHENOTYPES WHEN TWO CHARACTERISTICS ARE GOVER.NED BY THREE GENE PAIRS.

The Symbols $\mathrm{Bb}$ and $\mathrm{Cc}$ represent the epistatic gene pairs in each case.

\begin{tabular}{|c|c|c|c|c|c|}
\hline \multicolumn{3}{|c|}{ Backcross to triple recessive } & & & \\
\hline \multirow{2}{*}{ Phenotype } & \multicolumn{2}{|r|}{ Frequency } & & & \\
\hline & Observed & Expected & & & \\
\hline 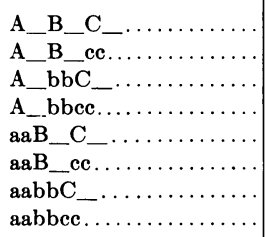 & $\begin{array}{l}o \\
q \\
r \\
s \\
t \\
u \\
v \\
w\end{array}$ & $\begin{array}{l}1 / 4 p \\
1 / 4 p \\
1 / 4(1-p) \\
1 / 4(1-p) \\
1 / 4(1-p) \\
1 / 4(1-p) \\
1 / 4 p \\
1 / 4 p\end{array}$ & & & \\
\hline \multicolumn{3}{|c|}{ Complementary pair } & \multicolumn{3}{|c|}{ Duplicate pair } \\
\hline \multirow{2}{*}{ Phenotype } & \multicolumn{2}{|r|}{ Frequency } & \multirow{2}{*}{ Phenotype } & \multicolumn{2}{|c|}{ Frequency } \\
\hline & Observed & Expected & & Observed & Expected \\
\hline $\begin{array}{l}\mathrm{AABC} \ldots \ldots \ldots \ldots \\
\mathrm{AaBC} \ldots \ldots \ldots \ldots \ldots \\
\mathrm{a} B \mathrm{BC} \ldots \ldots \ldots \ldots \ldots \\
\mathrm{AABc}(\mathrm{bC}, \mathrm{bc}) \ldots \ldots \\
\mathrm{AaBc}(\mathrm{bC}, \mathrm{bc}) \ldots \ldots \ldots \ldots \\
\mathrm{a} a \mathrm{aBc}(\mathrm{bC}, \mathrm{bc}) \ldots \ldots \ldots\end{array}$ & $\begin{array}{l}a^{\prime} \\
b^{\prime} \\
c^{\prime} \\
d^{\prime} \\
e^{\prime} \\
f^{\prime}\end{array}$ & $\begin{array}{l}1 / 8\left(3 p-p^{2}\right) \\
3 / 8\left(1-p+p^{2}\right) \\
3 / 16\left(1-p^{2}\right) \\
1 / 16\left(4-6 p+3 p^{2}\right) \\
1 / 8\left(1+3 p-3 p^{2}\right) \\
1 / 16\left(1+3 p^{2}\right)\end{array}$ & 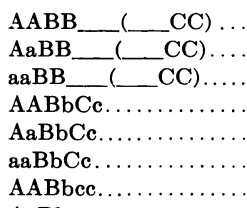 & $\begin{array}{l}g^{\prime} \\
h^{\prime} \\
i^{\prime} \\
j^{\prime} \\
k^{\prime} \\
l^{\prime} \\
m^{\prime}\end{array}$ & $\begin{array}{l}1 / 16\left(1+3 p^{2}\right) \\
1 / 8\left(1+3 p-3 p^{2}\right) \\
1 / 16\left(4-6 p+3 p^{2}\right) \\
1 / 4 p(1-p) \\
1 / 4\left(1-2 p+2 p^{2}\right) \\
1 / 4 p(1-p) \\
1 / 8(1-p)\end{array}$ \\
\hline \multicolumn{3}{|c|}{ Gene pair producing $13: 3$} & & & \\
\hline \multirow{2}{*}{ Phenotype } & \multicolumn{2}{|r|}{ Frequency } & Aabbcc............... & $\begin{array}{l}q \\
r^{\prime}\end{array}$ & $\begin{array}{l}1 / 10(1-p)^{2} \\
1 / 8 p(1-p)\end{array}$ \\
\hline & Observed & Expected & & & \\
\hline $\begin{array}{l}\mathrm{AABC}(\mathrm{Bcc}, \mathrm{bbcc}) \ldots \ldots \\
\mathrm{AaBc}(\mathrm{Bcc}, \mathrm{bbcc}) \ldots \ldots \\
\mathrm{a} B \mathrm{BC}(\mathrm{Bcc}, \mathrm{bbcc}) \ldots \ldots \\
\mathrm{AAbbC} \ldots \ldots \ldots \ldots \\
\mathrm{AabbC} \ldots \ldots \ldots \ldots \ldots \\
\text { aabbC } \ldots \ldots \ldots \ldots\end{array}$ & $\begin{array}{l}t^{\prime} \\
u^{\prime} \\
v^{\prime} \\
w^{\prime} \\
x^{\prime} \\
y^{\prime}\end{array}$ & $\begin{array}{l}1 / 16\left(1+6 p-3 p^{2}\right) \\
1 / 8\left(4-3 p+3 p^{2}\right) \\
1 / 16\left(4-3 p^{2}\right) \\
3 / 16(1-p)^{2} \\
3 / 8 p(1-p) \\
3 / 16 p^{2}\end{array}$ & & & \\
\hline
\end{tabular}




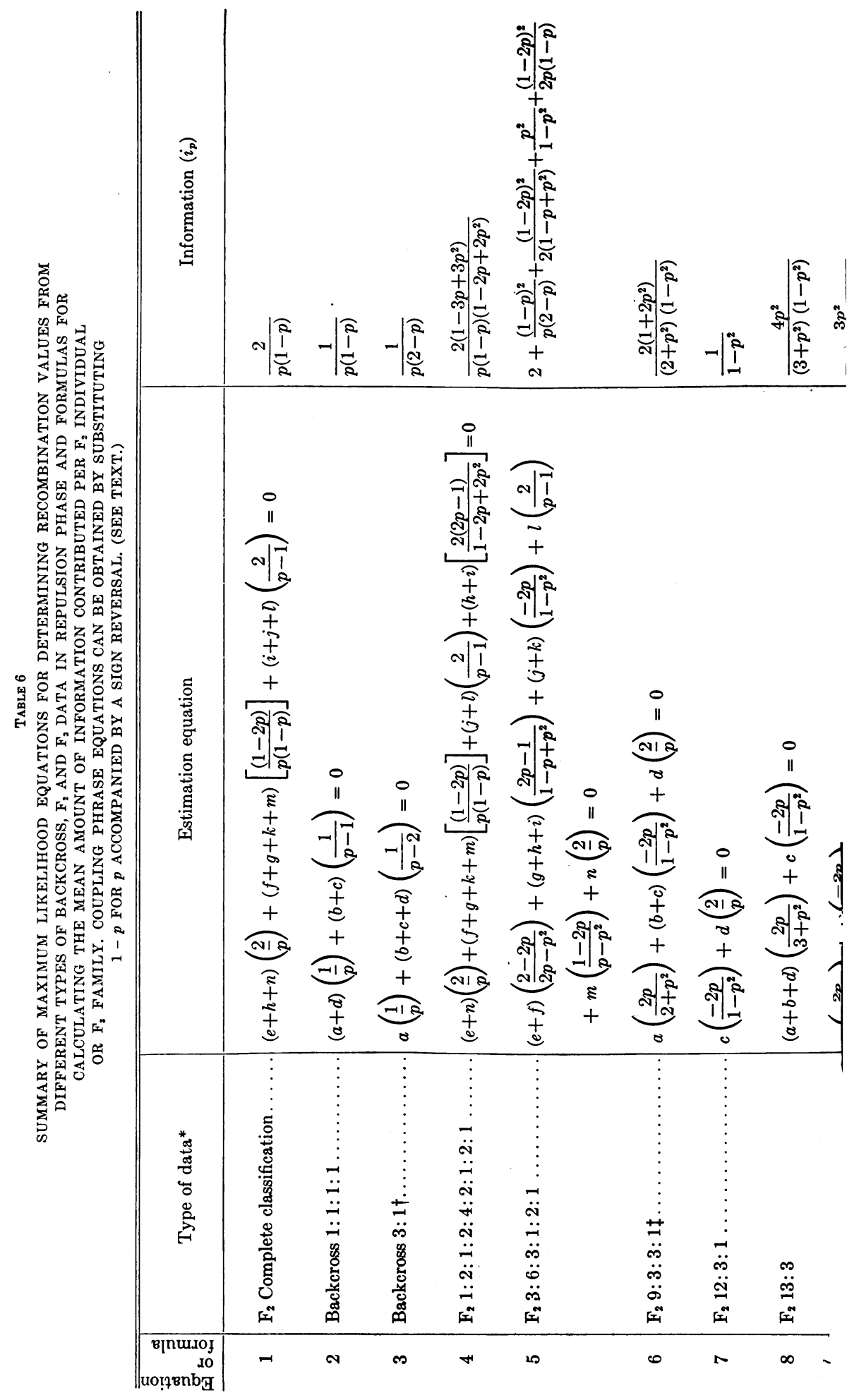




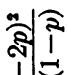

s:

क्षे

î:

"

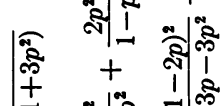

余令

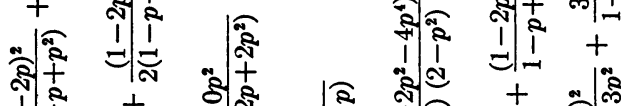

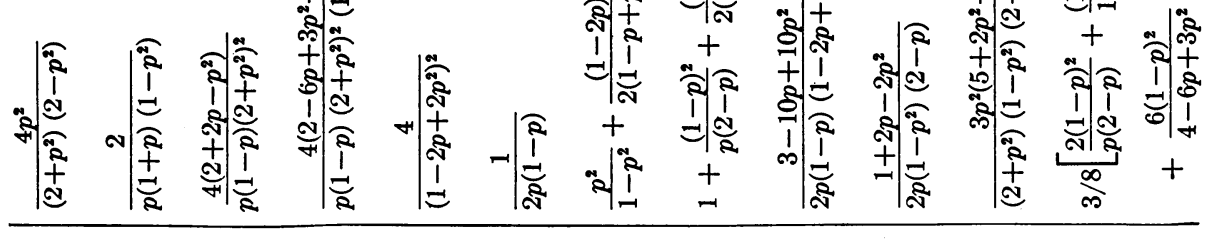

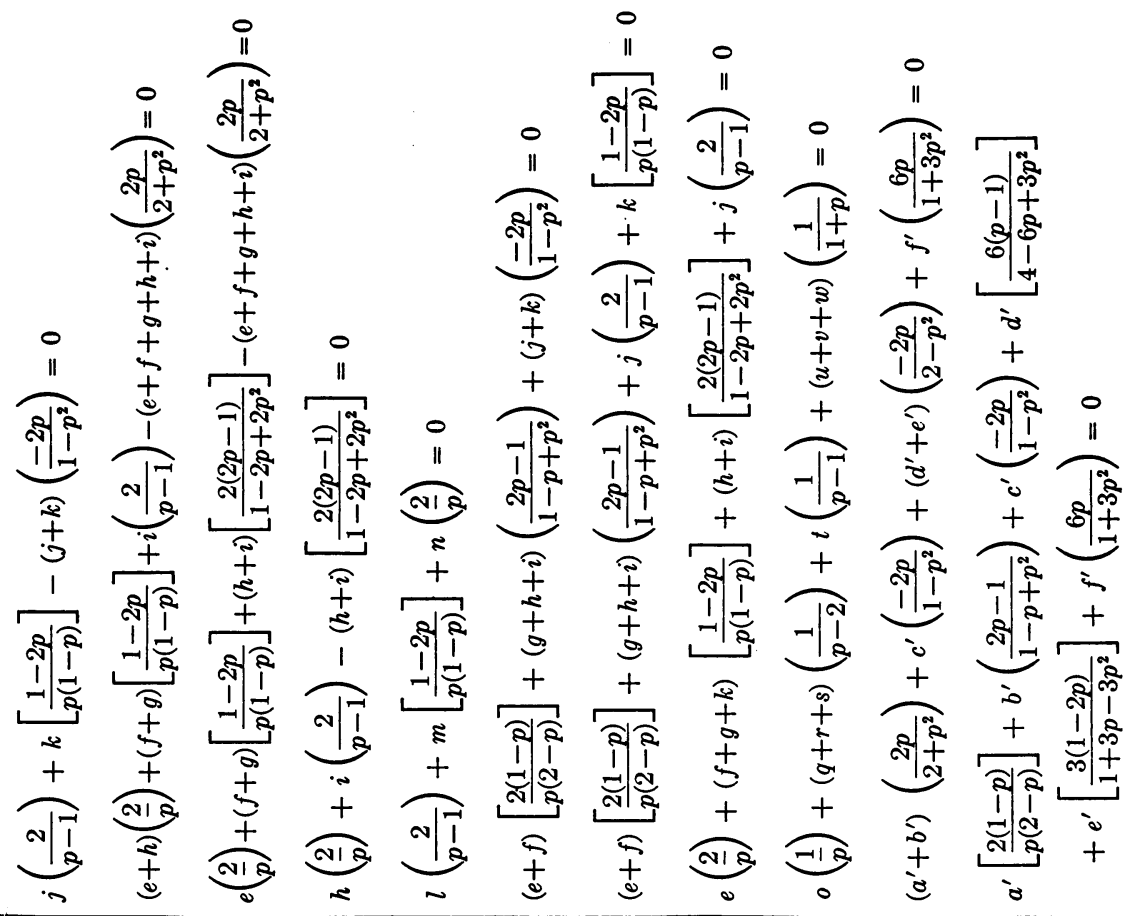

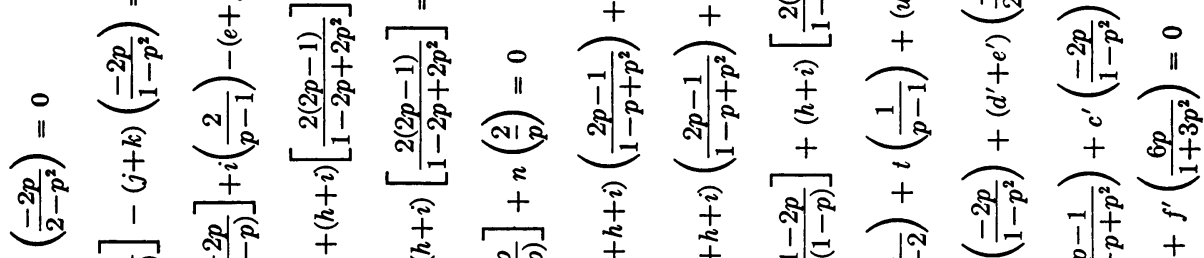

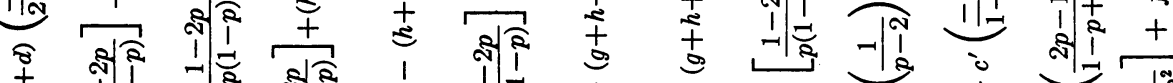

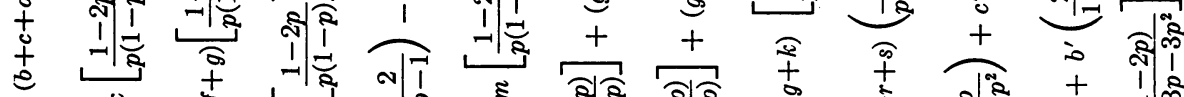

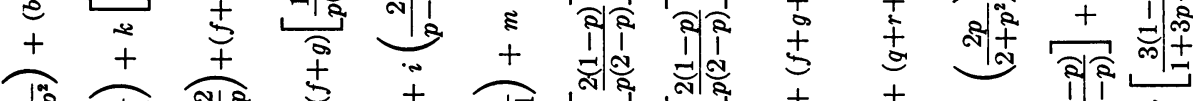

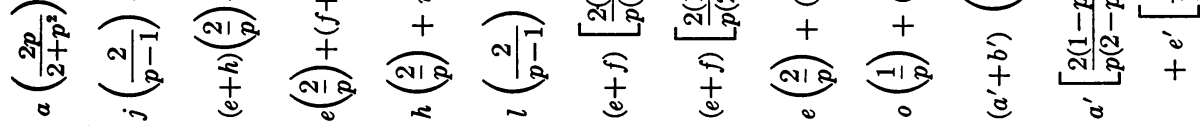

离

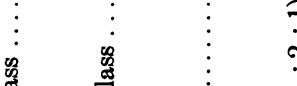

藏

.

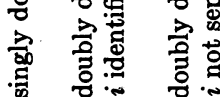

$\therefore$ 总 总㻤 总

我 क

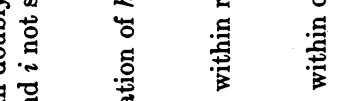

$\ddot{\bar{亠}}$

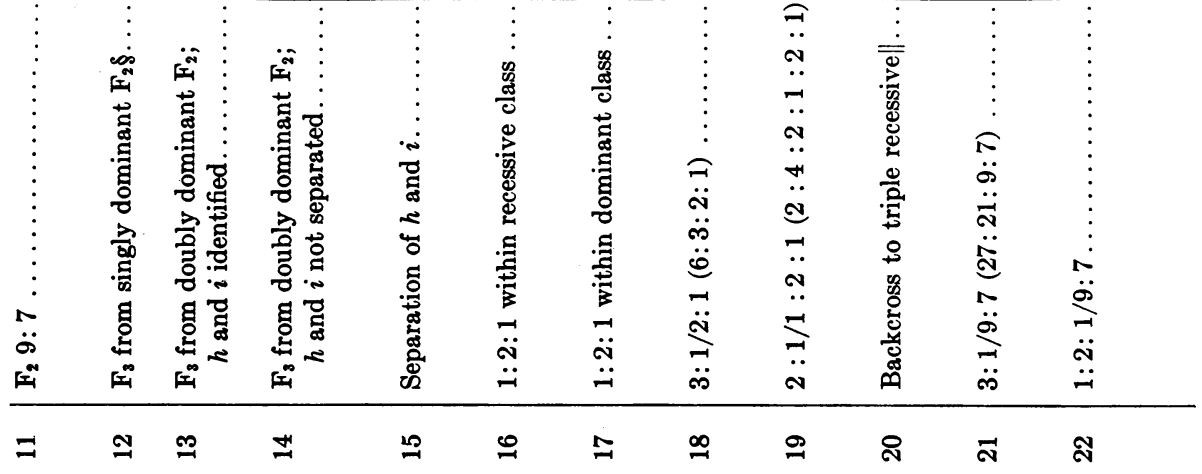




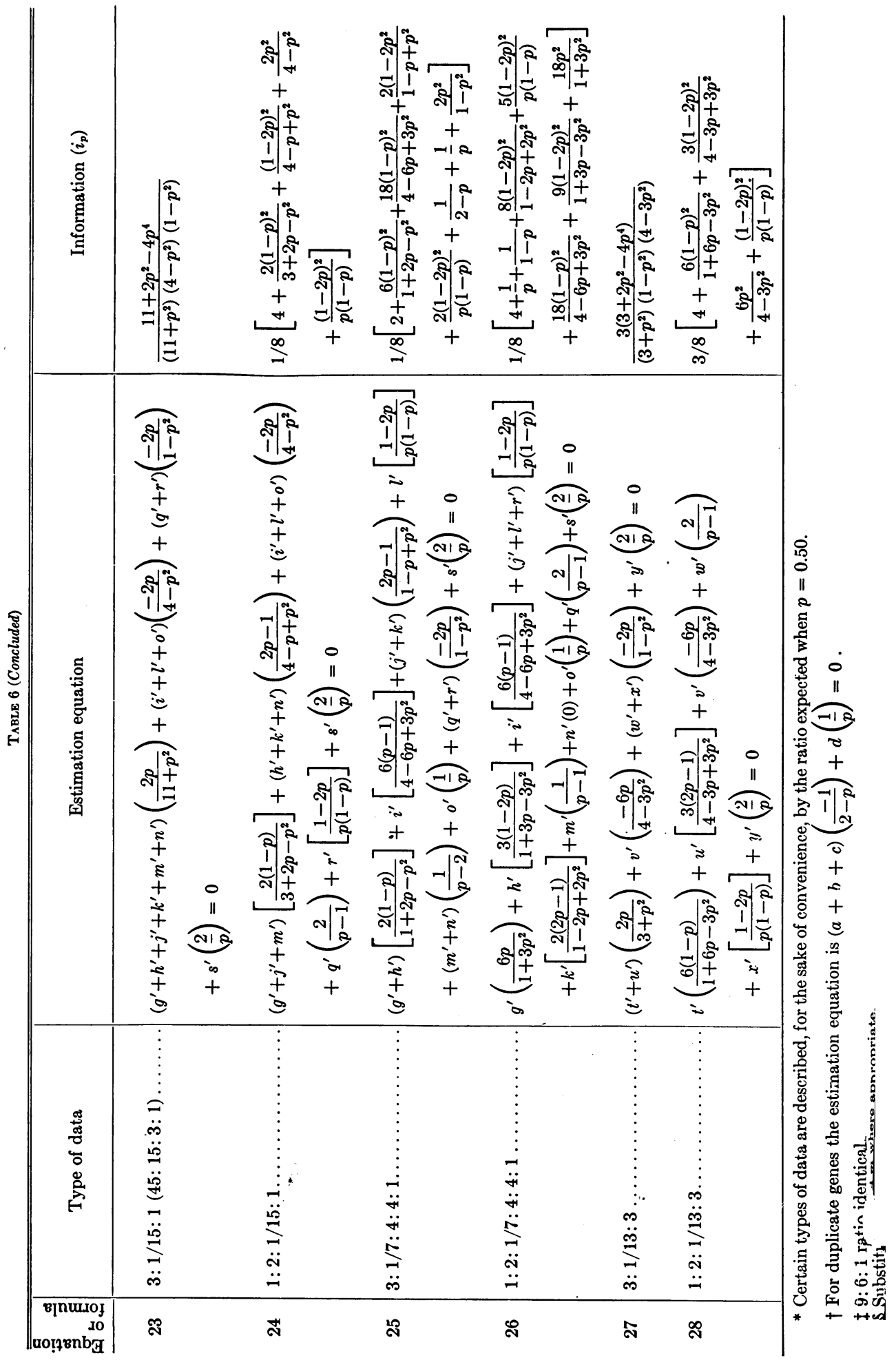



TABLE 7

SCORES FOR THE SOLUTION OF MAXIMUM LIKELIHOOD EQUATIONS USED IN THE ESTIMATION OF RECOMBINATION VALUES*

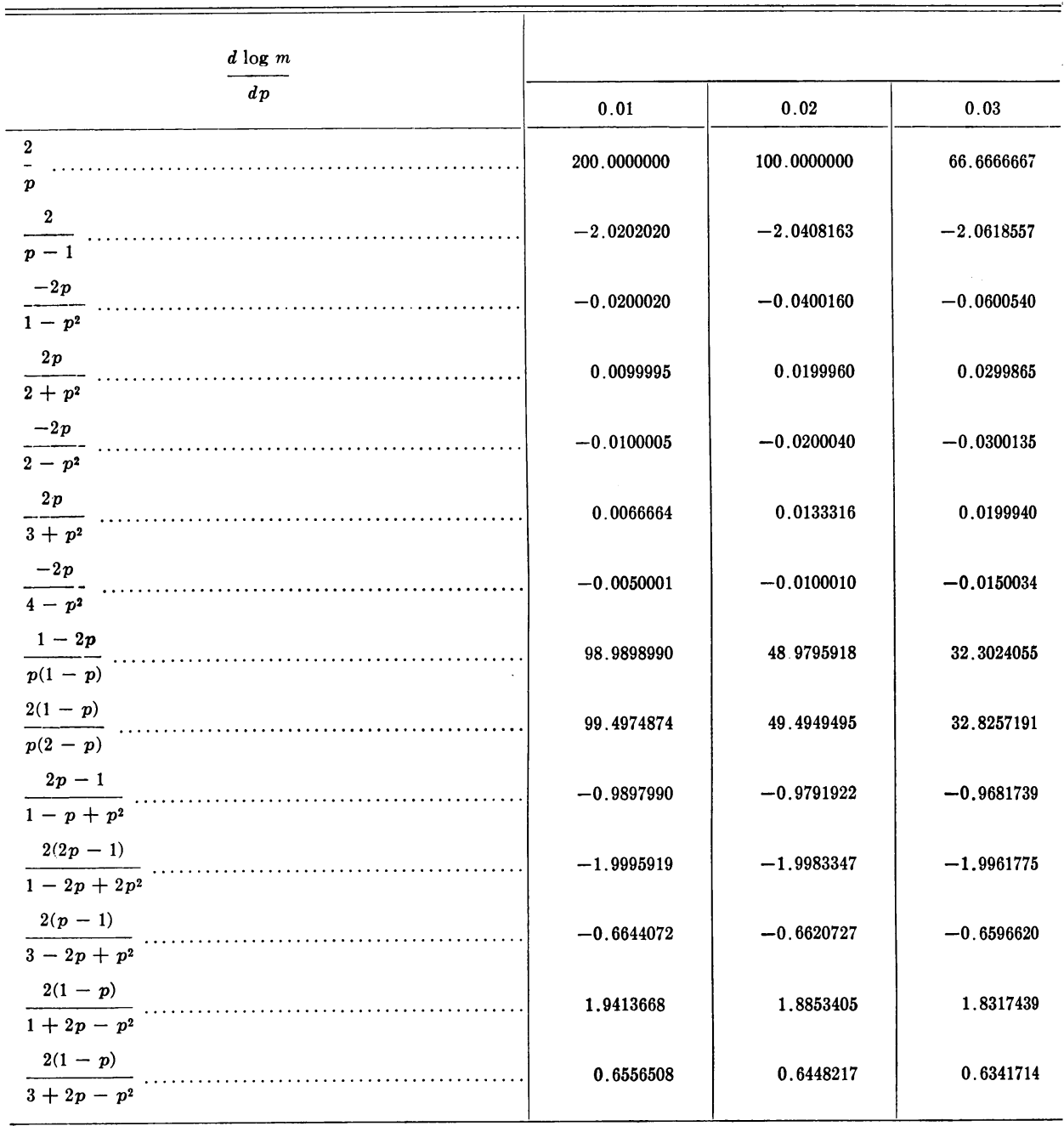

* The error in $p$ values calculated from these scores depends upon the population size $(n)$ and the number of scores (s) in the estimation equation. It may be calculated as $E_{\mathrm{p}}=5 n s \times 10^{-8}$. 


\begin{tabular}{|c|c|c|c|c|c|c|}
\hline Value of $p$ & & & & & & \\
\hline 0.04 & 0.05 & 0.06 & 0.07 & 0.08 & 0.09 & 0.10 \\
\hline 50.0000000 & 40.0000000 & 33.3333333 & 28.5714286 & 25.0000000 & 22.2222222 & 20.0000000 \\
\hline-2.0833333 & -2.1052632 & -2.1276596 & -2.1505376 & -2.1739130 & -2.1978022 & -2.2222222 \\
\hline-0.0801282 & -0.1002506 & -0.1204336 & -0.1406894 & -0.1610306 & -0.1814699 & -0.2020202 \\
\hline 0.0399680 & 0.0499376 & 0.0598922 & 0.0698289 & 0.0797448 & 0.0896370 & 0.0995025 \\
\hline-0.0400320 & -0.0500626 & -0.0601082 & -0.0701719 & -0.0802568 & -0.0903660 & -0.1005025 \\
\hline 0.0266525 & 0.0333056 & 0.0399521 & 0.0465906 & 0.0532198 & 0.0598384 & 0.0664452 \\
\hline-0.0200080 & -0.0250156 & -0.0300270 & -0.0350429 & -0.0400641 & -0.0450913 & -0.0501253 \\
\hline 23.9583333 & 18.9473684 & 15.6028369 & 13.2104455 & 11.4130435 & 10.0122100 & 8.8888889 \\
\hline 24.4897959 & 19.4871795 & 16.1512027 & 13.7675796 & 11.9791667 & 10.5875509 & 9.4736842 \\
\hline-0.9567387 & -0.9448819 & -0.9325986 & -0.9198845 & -0.9067358 & -0.8931489 & -0.8791209 \\
\hline-1.9930676 & -1.9889503 & -1.9837692 & -1.9774660 & -1.9699812 & -1.9612533 & -1.9512195 \\
\hline-0.6571742 & -0.6546081 & -0.6519628 & -0.6492373 & -0.6464306 & -0.6435416 & -0.6405694 \\
\hline 1.7804154 & 1.7312073 & 1.6839842 & 1.6386221 & 1.5950069 & 1.5530335 & 1.5126050 \\
\hline 0.6237006 & 0.6133979 & 0.6032602 & 0.5932825 & 0.5834602 & 0.5737886 & 0.5642633 \\
\hline
\end{tabular}


TABLE 7-(Continued)

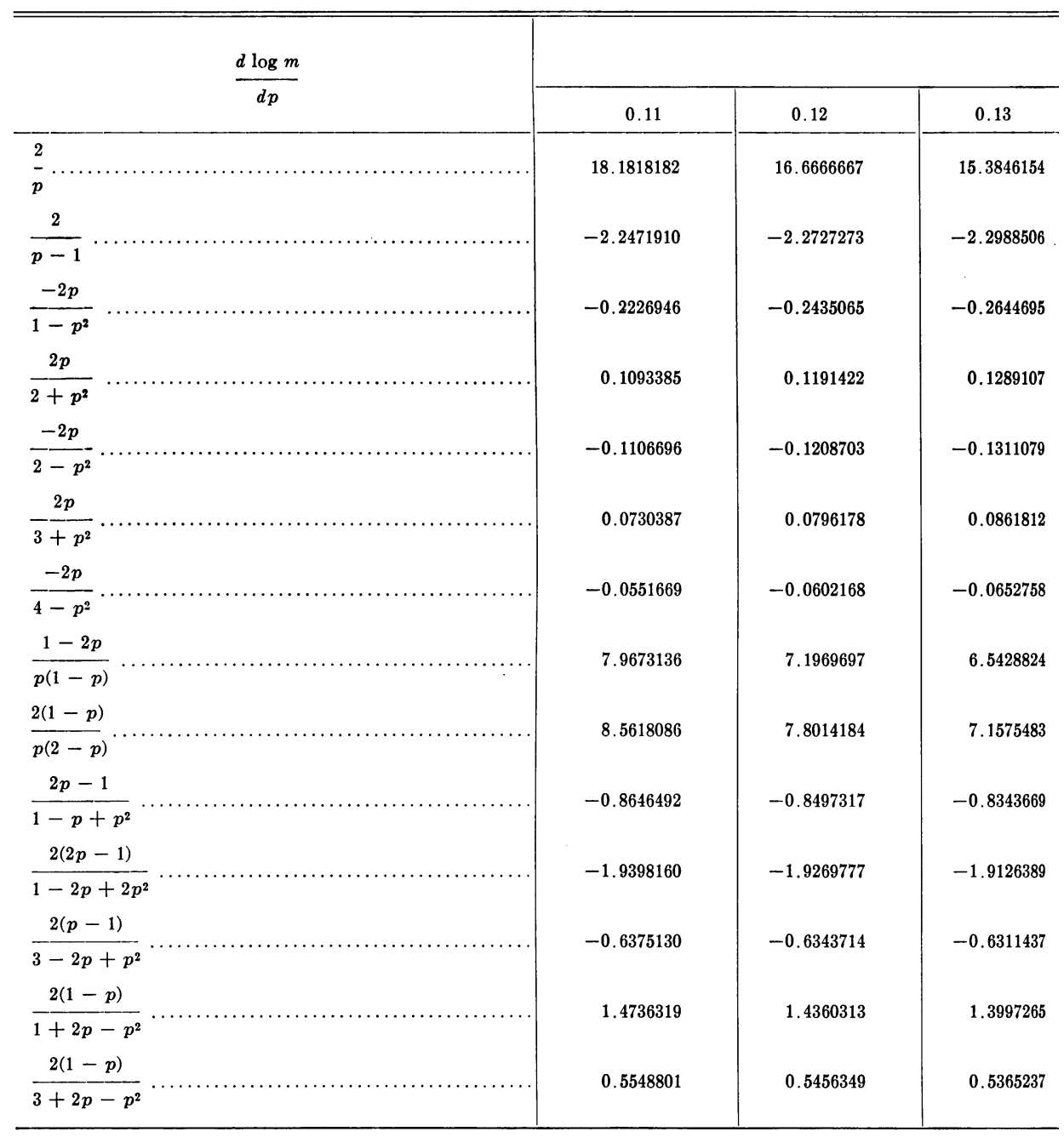




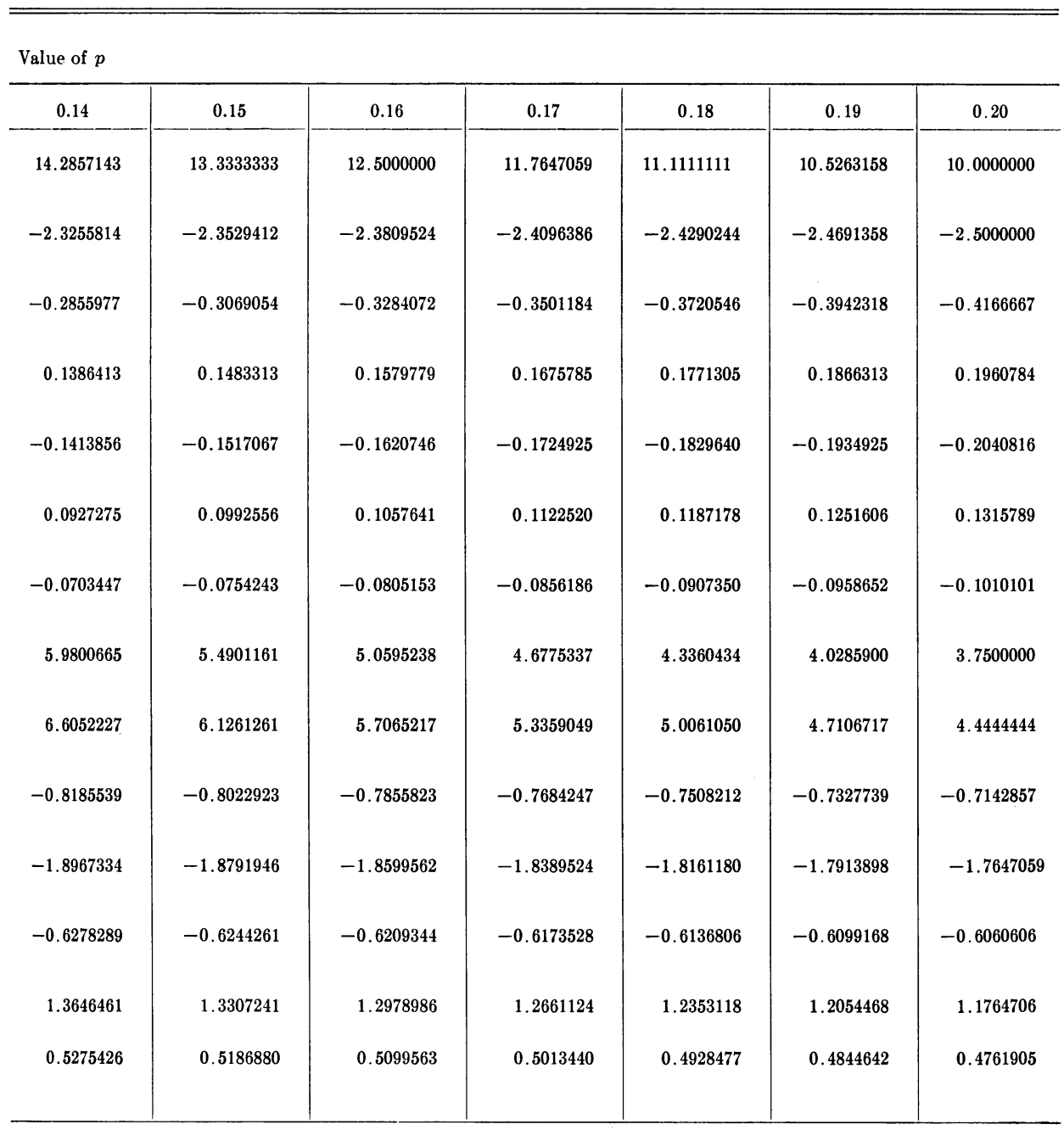


TABLE 7-(Continued)

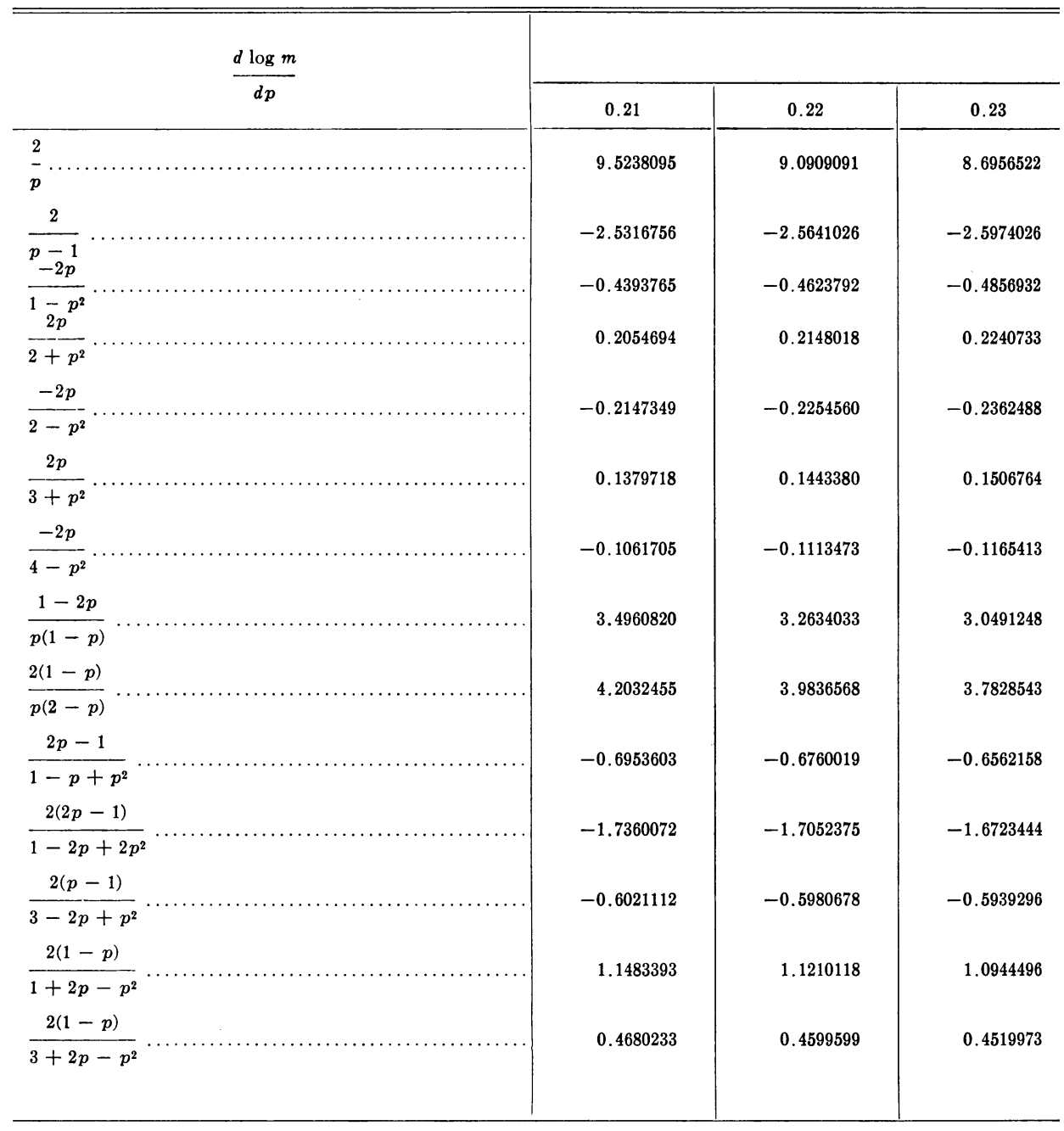




\begin{tabular}{|c|c|c|c|c|c|c|}
\hline Value of $p$ & & & & & & \\
\hline 0.24 & 0.25 & 0.26 & 0.27 & 0.28 & 0.29 & 0.30 \\
\hline 8.3333333 & 8.0000000 & 7.6923077 & 7.4074074 & 7.1428571 & 6.8965517 & 6.6666667 \\
\hline-2.6315789 & -2.6666667 & -2.7027027 & -2.7397260 & -2.7777778 & -2.8169014 & -2.8571429 \\
\hline-0.5093379 & -0.5333333 & -0.5577006 & -0.5824614 & -0.6076389 & -0.6332569 & -0.6593407 \\
\hline 0.2332815 & 0.2424242 & 0.2514993 & 0.2605046 & 0.2694380 & 0.2782976 & 0.2870813 \\
\hline-0.2471170 & -0.2580645 & -0.2690954 & -0.2802138 & -0.2914238 & -0.3027298 & -0.3141361 \\
\hline 0.1569859 & 0.1632653 & 0.1695136 & 0.1757298 & 0.1819127 & 0.1880613 & 0.1941748 \\
\hline-0.1217533 & -0.1269841 & -0.1322348 & -0.1375061 & -0.1427989 & -0.1481141 & -0.1534527 \\
\hline 2.8508772 & 2.6666667 & 2.4948025 & 2.3338407 & 2.1825397 & 2.0398252 & 1.9047619 \\
\hline 3.5984848 & 3.4285714 & 3.2714412 & 3.1255669 & 2.9900332 & 2.8634805 & 2.7450980 \\
\hline-0.6360078 & -0.6153846 & -0.5943536 & -0.5729232 & -0.5511022 & -0.5289006 & -0.5063291 \\
\hline-1.6372796 & -1.6000000 & -1.5604681 & -1.5186530 & -1.4745308 & -1.4280857 & -1.3793103 \\
\hline-0.5896958 & -0.5853659 & -0.5809389 & -0.5764144 & -0.5717916 & -0.5670700 & -0.5622490 \\
\hline 1.0686164 & 1.0434783 & 1.0190030 & 0.9951605 & 0.9719222 & 0.9492613 & 0.9271523 \\
\hline 0.4441328 & 0.4363636 & 0.4286873 & 0.4211012 & 0.4136029 & 0.4061901 & 0.3988604 \\
\hline
\end{tabular}


TABLE 7-(Continued $)$

\begin{tabular}{|c|c|c|c|c|}
\hline & \multirow{2}{*}{$\frac{d \log m}{d p}$} & \multirow[b]{2}{*}{0.31} & \multirow[b]{2}{*}{0.32} & \multirow[b]{2}{*}{0.33} \\
\hline & & & & \\
\hline 2 & & \multirow[t]{2}{*}{6.4516129} & \multirow[t]{2}{*}{6.2500000} & \multirow[t]{2}{*}{6.060606} \\
\hline$p$ & & & & \\
\hline 2 & & \multirow{2}{*}{-2.8985507} & \multirow[t]{2}{*}{-2.9411765} & \multirow{2}{*}{-2.9850746} \\
\hline$p-1$ & & & & \\
\hline$-2 p$ & & \multirow{2}{*}{-0.6859166} & \multirow{2}{*}{-0.7130125} & \multirow{2}{*}{-0.7406576} \\
\hline $1-p^{2}$ & & & & \\
\hline $2 p$ & & \multirow{2}{*}{0.2957874} & \multirow{2}{*}{0.3044140} & \multirow{2}{*}{0.3129594} \\
\hline $2+p^{2}$ & & & & \\
\hline$-2 p$ & & \multirow{2}{*}{-0.3256474} & \multirow{2}{*}{-0.3372681} & \multirow{2}{*}{-0.3490032} \\
\hline $2-p^{2}$ & & & & \\
\hline $2 p$ & & \multirow{2}{*}{0.2002519} & \multirow{2}{*}{0.2062919} & \multirow{2}{*}{0.2122937} \\
\hline $3+p^{2}$ & & & & \\
\hline$-2 p$ & & \multirow{2}{*}{-0.1588155} & \multirow{2}{*}{-0.1642036} & \multirow{2}{*}{-0.1696179} \\
\hline $4-p^{2}$ & & & & \\
\hline $1-2 p$ & & \multirow{2}{*}{1.7765311} & \multirow{2}{*}{1.6544118} & \multirow{2}{*}{1.5377657} \\
\hline$\overline{p(1-p)}$ & & & & \\
\hline $2(1-p)$ & & \multirow{2}{*}{2.6340905} & \multirow{2}{*}{2.5297619} & \multirow{2}{*}{2.4315006} \\
\hline$p(2-p)$ & & & & \\
\hline $2 p-1$ & & \multirow{2}{*}{-0.4833991} & -0.4601227 & -0.4365130 \\
\hline $1-p+p^{2}$ & & & -0.4001228 & -0.4500100 \\
\hline $2(2 p-1)$ & & -13282060 & -12747875 & -12100740 \\
\hline$\overline{1-2 p+2 p^{2}}$ & & -1.3282069 & -1.2747875 & -1.2190749 \\
\hline $2(p-1)$ & & -05573981 & -05502067 & 05471845 \\
\hline $3-2 p+p^{2}$ & & & & \\
\hline $2(1-p)$ & & 09055712 & 08844053 & 0.8630030 \\
\hline $1+2 p-p^{2}$ & & 0.8000016 & 0.0047800 & 0.0008000 \\
\hline $2(1-p)$ & & 0.3916116 & 0.3844414 & 0.3773479 \\
\hline $3+2 p-p^{2}$ & & 0.0910110 & 0.0044414 & \\
\hline
\end{tabular}




\begin{tabular}{|c|c|c|c|c|c|c|}
\hline Value of $p$ & & & & & & \\
\hline 0.34 & 0.35 & 0.36 & 0.37 & 0.38 & 0.39 & 0.40 \\
\hline 5.8823529 & 5.7142857 & 5.5555556 & 5. 4054054 & 5.2631579 & 5.1282051 & 5.0000000 \\
\hline-3.0303030 & -3.0769231 & -3.1250000 & -3.1746032 & -3.2258065 & -3.2786885 & -3.3333333 \\
\hline-0.7688829 & -0.7977208 & -0.8272059 & -0.8573746 & -0.8882655 & -0.9199198 & -0.9523810 \\
\hline 0.3214218 & 0.3297998 & 0.3380917 & 0.3462960 & 0.3544115 & 0.3624367 & 0.3703704 \\
\hline-0.3608576 & -0.3728362 & -0.3849444 & -0.3971875 & -0.4095710 & -0.4221008 & -0.4347826 \\
\hline 0.2182565 & 0.2241793 & 0.2300613 & 0.2359017 & 0.2416995 & 0.2474541 & 0.2531646 \\
\hline-0.1750592 & -0.1805287 & -0.1860273 & -0.1915560 & -0.1971159 & -0.2027080 & -0.2083333 \\
\hline 1.4260250 & 1.3186813 & 1.2152778 & 1.1154011 & 1.0186757 & 0.9247583 & 0.8333333 \\
\hline 2.3387668 & 2.2510823 & 2.1680217 & 2.0892058 & 2.0142950 & 1.9429846 & 1.8750000 \\
\hline-0.4125838 & -0.3883495 & -0.3638254 & -0.3390273 & -0.3139717 & -0.2886760 & -0.2631579 \\
\hline-1.1611030 & -1.1009174 & -1.0385757 & -0.9741476 & -0.9077156 & -0.8393743 & -0.7692308 \\
\hline-0.5419609 & -0.5366357 & -0.5312085 & -0.5256790 & -0.5200470 & -0.5143122 & -0.5084746 \\
\hline 0.8437740 & 0.8240887 & 0.8048290 & 0.7859772 & 0.7675167 & 0.7494318 & 0.7317073 \\
\hline 0.3703288 & 0.3633823 & 0.3565062 & 0.3496989 & 0.3429583 & 0.3362827 & 0.3296703 \\
\hline
\end{tabular}


TABLE 7-(Continued)

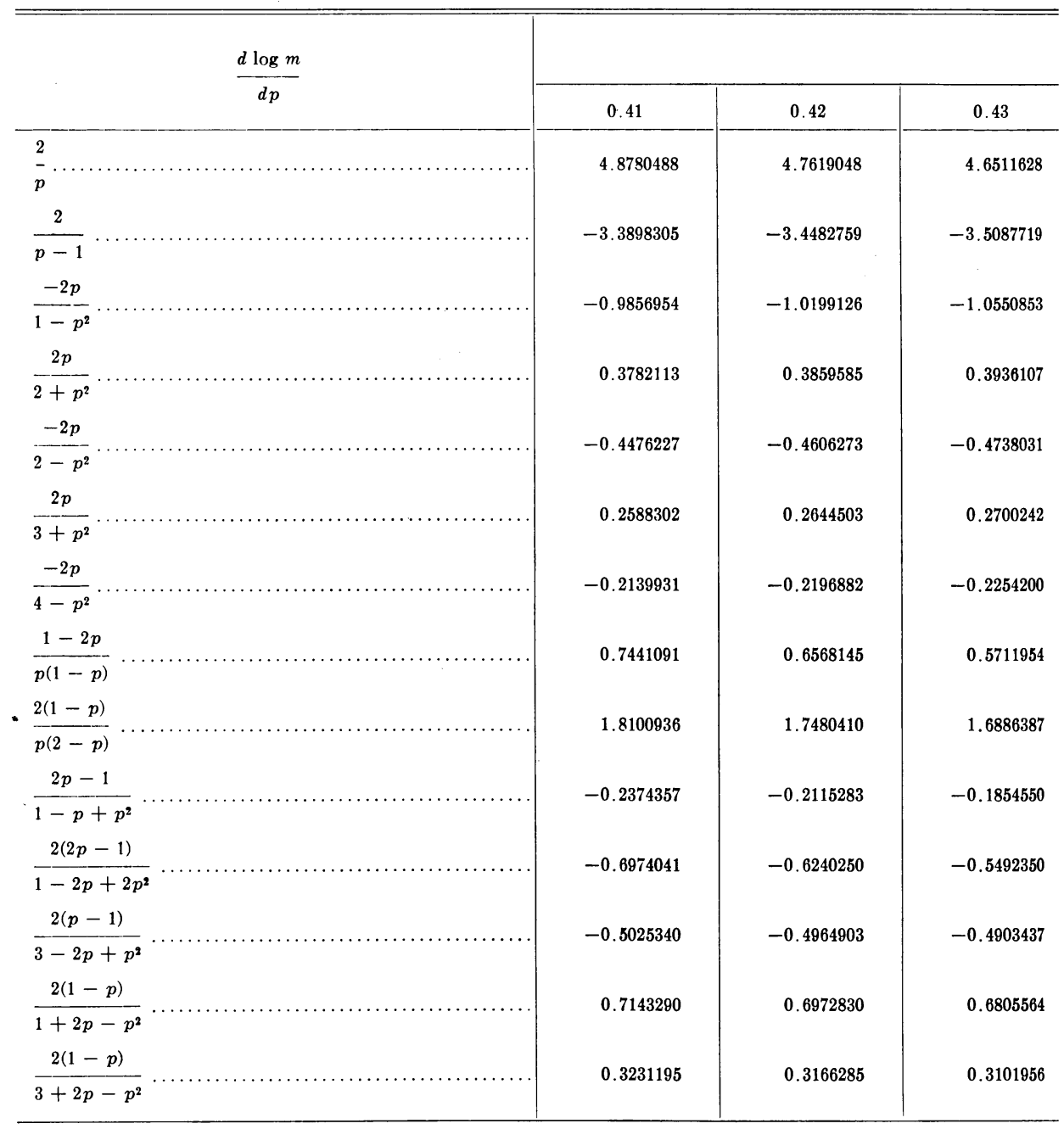




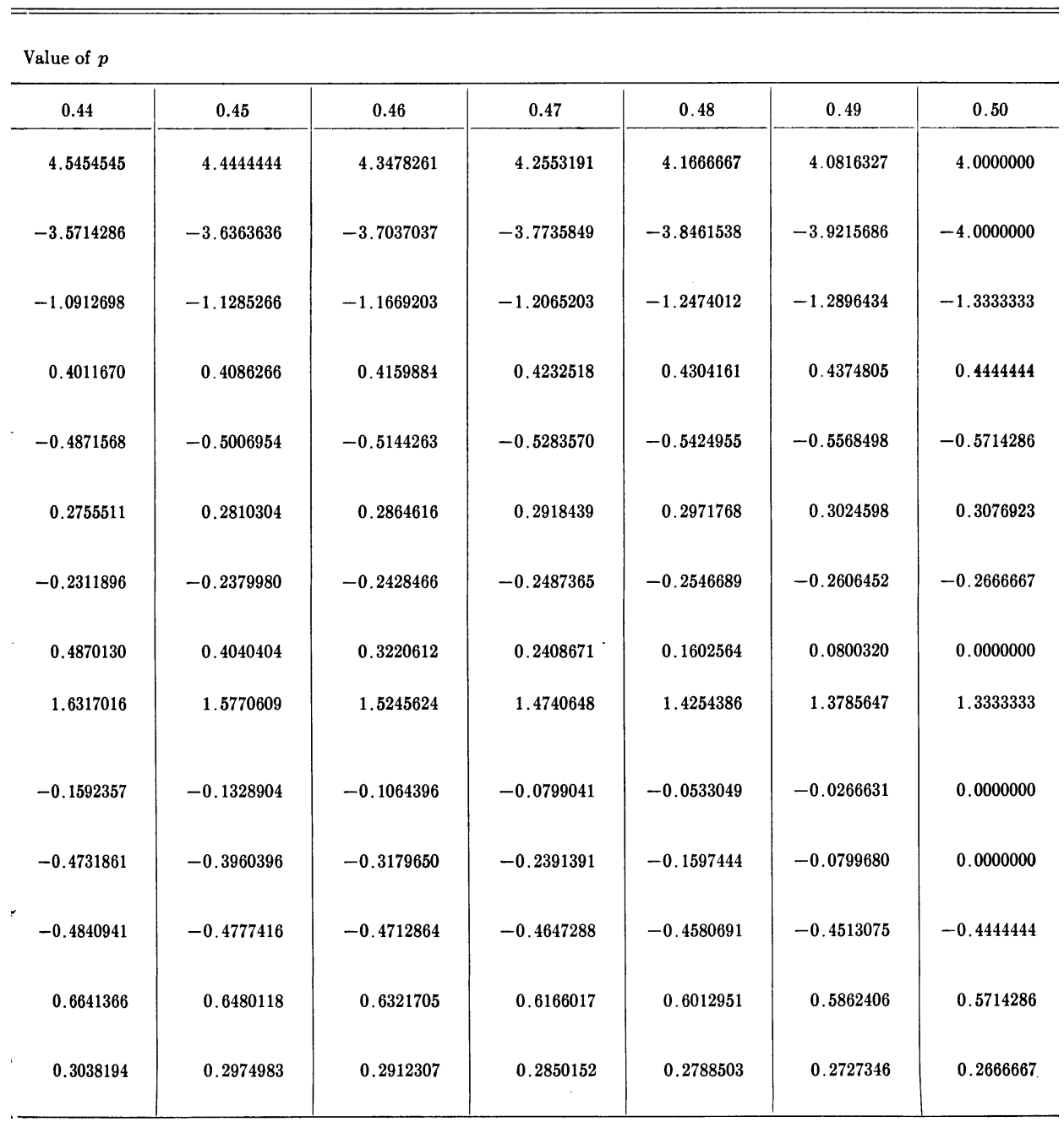


TABLe 7-(Concluded)

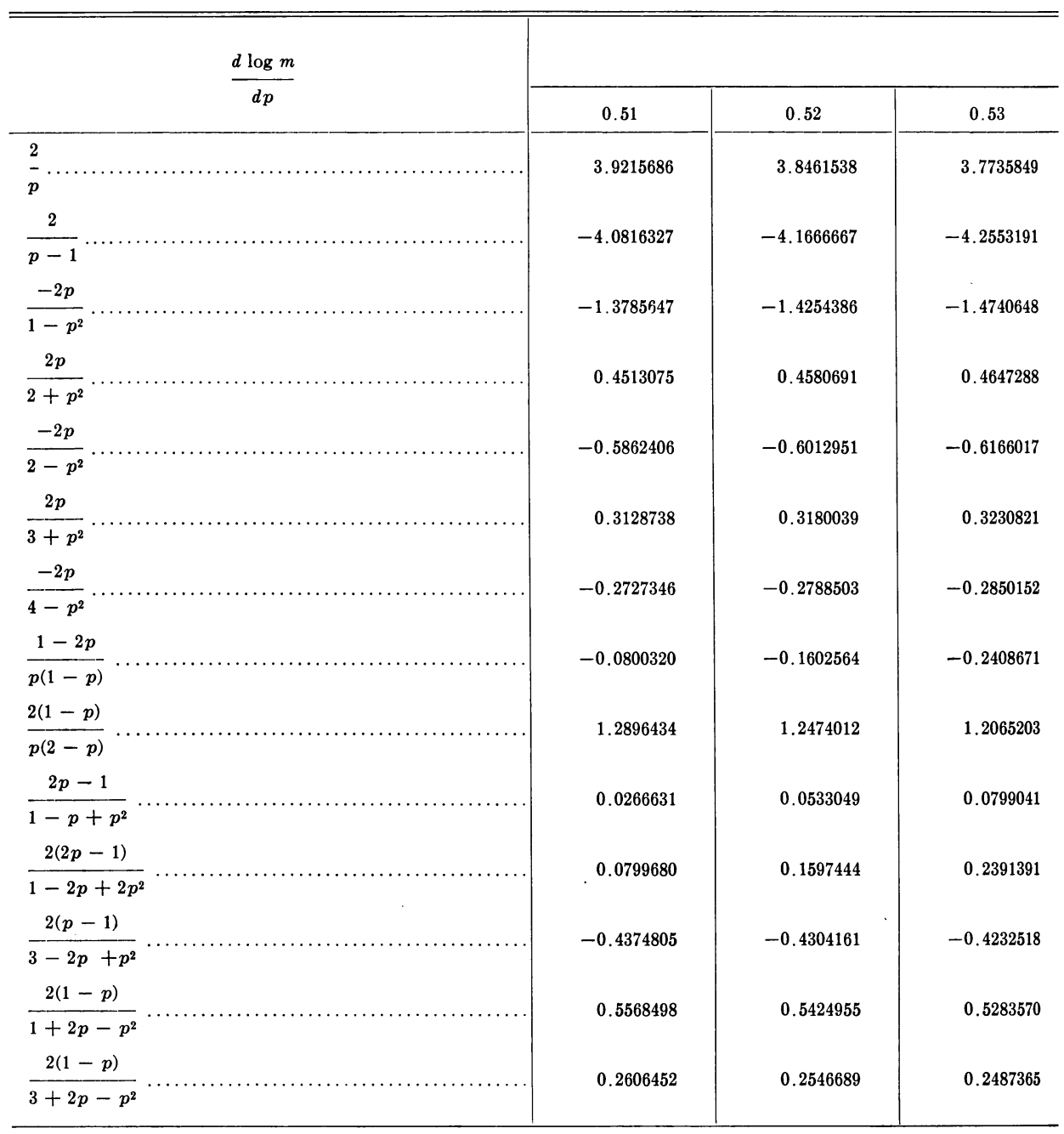


Value of $p$

\begin{tabular}{|c|c|c|c|c|}
\hline 0.54 & 0.55 & 0.56 & 0.57 & \\
\hline 3.7037037 & 3.6363636 & 3.5714286 & 3.5087719 & \\
\hline-4.3478261 & -4.4444444 & -4.5454545 & -4.6511628 & \\
\hline-1.5245624 & -1.5770609 & -1.6317016 & -1.6886387 & \\
\hline 0.4712864 & 0.4777416 & 0.4840941 & 0.4903437 & \\
\hline-0.6321705 & -0.6480118 & -0.6641366 & -0.6805564 & \\
\hline 0.3281079 & 0.3330810 & 0.3380010 & 0.3428675 & \\
\hline-0.2912307 & -0.2974983 & -0.3038194 & -0.3101956 & \\
\hline-0.3220612 & -0.4040404 & -0.4870130 & -0.5711954 & \\
\hline 1.1669203 & 1.1285266 & 1.0912698 & 1.0550853 & \\
\hline 0.1064396 & 0.1328904 & 0.1592357 & 0.1854550 & \\
\hline 0.3179650 & 0.3960396 & 0.4731861 & 0.5492350 & \\
\hline-0.4159884 & -0.4086266 & -0.4011670 & -0.3936107 & \\
\hline 0.5144263 & 0.5006954 & 0.4871568 & 0.4738031 & \\
\hline 0.2428466 & 0.2369980 & 0.2311896 & 0.2254200 & \\
\hline
\end{tabular}




\section{TABLE 8}

INFORMATION PER $\mathrm{F}_{2}$ INDIVIDUAL OR $\mathrm{F}_{3}$ FAMILY FOR SEVERAL TYPES OF GENETIC SITUATIONS AT VARIOUS RECOMBINATION VALUES*

\begin{tabular}{|c|c|c|c|c|c|c|c|c|c|c|c|c|}
\hline \multirow{2}{*}{$\begin{array}{l}\text { For- } \\
\text { mula }\end{array}$} & \multirow{2}{*}{ Гype of data } & \multirow{2}{*}{$\begin{array}{c}\text { Link- } \\
\text { age } \\
\text { phase }\end{array}$} & \multicolumn{10}{|c|}{ Value of $p$} \\
\hline & & & 0.01 & 0.02 & 0.03 & 0.04 & 0.05 & 0.06 & 0.07 & 0.08 & 0.09 & 0.10 \\
\hline 1 & $\begin{array}{r}F_{2,} \text { complete classi- } \\
\text { fication } \dagger \ldots . . . \ldots \ldots\end{array}$ & & 202.020 & 102.041 & 68.364 & 52.083 & 42.105 & 35.461 & 30.722 & 27.174 & 24.420 & 22.222 \\
\hline 3 & Backcross $\ddagger(3: 1)$.. & $\begin{array}{l}\mathrm{R} \\
\mathrm{C}\end{array}$ & $\begin{array}{r}50.251 \\
1.000\end{array}$ & $\begin{array}{r}25.252 \\
1.000\end{array}$ & $\begin{array}{r}16.920 \\
1.001\end{array}$ & $\begin{array}{r}12.755 \\
1.002\end{array}$ & $\begin{array}{r}10.256 \\
1.003\end{array}$ & $\begin{array}{l}8.591 \\
1.004\end{array}$ & $\begin{array}{l}7.402 \\
1.005\end{array}$ & $\begin{array}{l}6.510 \\
1.006\end{array}$ & $\begin{array}{l}5.817 \\
1.008\end{array}$ & $\begin{array}{l}5.263 \\
1.010\end{array}$ \\
\hline 4 & $\begin{array}{l}\mathrm{F}_{2}, \\
\quad 1: 2: 1: 2: 4: 2: 1: 2: 1 \ldots\end{array}$ & & 199.980 & 99.959 & 66.605 & 49.900 & 39.895 & 33.207 & 28.423 & 24.829 & 22.028 & 19.783 \\
\hline 5 & $\mathrm{~F}_{2}, 3: 6: 3: 1: 2: 1$ & & 100.241 & 75.247 & 31.559 & 24.947 & 20.210 & 16.870 & 14.483 & 12.691 & 11.297 & 10.180 \\
\hline 6 & $\mathrm{~F}_{2,9} 9: 3: 3: 1 \ldots$ & $\begin{array}{l}\mathrm{R} \\
\mathrm{C}\end{array}$ & $\begin{array}{r}1.000 \\
99.831\end{array}$ & $\begin{array}{r}1.001 \\
49.829\end{array}$ & $\begin{array}{r}1.002 \\
33.161\end{array}$ & $\begin{array}{r}1.004 \\
24.826\end{array}$ & $\begin{array}{r}1.006 \\
19.824\end{array}$ & $\begin{array}{r}1.009 \\
16.489\end{array}$ & $\begin{array}{r}1.012 \\
14.106\end{array}$ & $\begin{array}{r}1.016 \\
12.318\end{array}$ & & $\begin{array}{l}1.025 \\
9.815\end{array}$ \\
\hline 8 & $\mathrm{~F}_{2}, 13: 3 \ldots$ & $\begin{array}{l}\mathrm{R} \\
\mathrm{C}\end{array}$ & $\begin{array}{r}0.000 \\
49.498\end{array}$ & $\begin{array}{r}0.001 \\
24.495\end{array}$ & $\begin{array}{r}0.001 \\
16.159\end{array}$ & $\begin{array}{r}0.002 \\
11.990\end{array}$ & & & & & & $\begin{array}{l}0.013 \\
4.476\end{array}$ \\
\hline 9 & $\mathrm{~F}_{2}, 9: 3: 4 \ldots$ & $\begin{array}{l}\mathrm{R} \\
\mathrm{C}\end{array}$ & $\begin{array}{r}0.000 \\
49.580\end{array}$ & $\begin{array}{r}0.001 \\
24.577\end{array}$ & $\begin{array}{r}0.001 \\
16.240\end{array}$ & $\begin{array}{r}0.002 \\
12.071\end{array}$ & $\begin{array}{l}0.004 \\
9.567\end{array}$ & $\begin{array}{l}0.005 \\
7.897\end{array}$ & $\begin{array}{l}0.007 \\
6.704\end{array}$ & & $\begin{array}{l}0.012 \\
5.110\end{array}$ & $\begin{array}{l}0.015 \\
4.551\end{array}$ \\
\hline 10 & $\mathrm{~F}_{2}, 15: 1 \ldots$ & $\underset{\mathrm{C}}{\mathrm{R}}$ & $\begin{array}{l}1.000 \\
1.325\end{array}$ & $\begin{array}{l}1.000 \\
1.316\end{array}$ & $\begin{array}{l}1.000 \\
1.308\end{array}$ & $\begin{array}{l}1.000 \\
1.299\end{array}$ & $\begin{array}{l}1.001 \\
1.291\end{array}$ & $\begin{array}{l}1.001 \\
1.284\end{array}$ & $\begin{array}{l}1.001 \\
1.276\end{array}$ & $\begin{array}{l}1.002 \\
1.268\end{array}$ & $\begin{array}{l}1.002 \\
1.261\end{array}$ & $\begin{array}{l}1.003 \\
1.254\end{array}$ \\
\hline 11 & $F_{2}, 9: 7$ & $\underset{\mathrm{C}}{\mathrm{R}}$ & $\begin{array}{l}0.000 \\
1.290\end{array}$ & $\begin{array}{l}0.000 \\
1.248\end{array}$ & & $\begin{array}{l}0.002 \\
1.120\end{array}$ & & & & & $\begin{array}{l}0.008 \\
0.999\end{array}$ & $\begin{array}{l}0.010 \\
0.969\end{array}$ \\
\hline 12 & $\begin{array}{l}\mathrm{F}_{3} \text { from singly } \\
\text { dominant } \mathrm{F}_{2} \ldots\end{array}$ & $\underset{\mathrm{C}}{\mathrm{R}}$ & $\begin{array}{r}198.040 \\
51.014\end{array}$ & & & & & & & & $\begin{array}{r}20.554 \\
6.694\end{array}$ & $\begin{array}{r}18.365 \\
6.156\end{array}$ \\
\hline 13 & $\begin{array}{l}\mathrm{F}_{3} \text { from doubly } \\
\text { dominant } \mathrm{F}_{2} ; h \\
\text { and } i \text { separated }\end{array}$ & $\begin{array}{l}\mathrm{R} \\
\mathrm{C}\end{array}$ & $\begin{array}{l}204.025 \\
136.480\end{array}$ & $\begin{array}{r}104.022 \\
69.850\end{array}$ & $\begin{array}{l}70.696 \\
47.665\end{array}$ & $\begin{array}{l}54.039 \\
36.591\end{array}$ & & & & & & $\begin{array}{l}24.092 \\
16.830\end{array}$ \\
\hline 14 & $\begin{array}{l}\mathrm{F}_{3} \text { from doubly } \\
\quad \text { dominant } \mathrm{F}_{2} ; h \\
\text { and } i \text { not sepa- } \\
\text { rated } . \ldots \ldots \ldots \ldots\end{array}$ & $\stackrel{\mathrm{R}}{\mathrm{C}}$ & $\begin{array}{l}199.929 \\
133.742\end{array}$ & & & $\begin{array}{l}49.709 \\
33.625\end{array}$ & & & & & $\begin{array}{l}21.541 \\
14.887\end{array}$ & $\begin{array}{l}19.238 \\
13.358\end{array}$ \\
\hline 15 & $\begin{array}{l}\text { Separation of } h \\
\quad \text { and } i \ldots \ldots \ldots \ldots \ldots\end{array}$ & & 4.163 & 4.333 & 4.510 & 4.693 & 4.884 & 5.081 & 5.287 & 5.500 & 5.721 & 5.949 \\
\hline 16 & $\begin{array}{l}1: 2: 1 \text { within re- } \\
\text { cession class..... }\end{array}$ & & 50.505 & 25.510 & 15.182 & 12.760 & 10.526 & 8.865 & 7.680 & 6.793 & 6.105 & 5.556 \\
\hline 17 & $\begin{array}{l}1: 2: 1 \text { within } \\
\text { dominant class.. }\end{array}$ & & 49.736 & 24.723 & 16.376 & 12.186 & 9.684 & 8.005 & 6.802 & 5.898 & 5.192 & 4.625 \\
\hline 18 & $\begin{array}{l}3: 1 / 2: 1 \\
\quad(6: 3: 2: 1) \ldots\end{array}$ & $\stackrel{\mathrm{R}}{\mathrm{C}}$ & & & & & & & & & & $\begin{array}{l}9.170 \\
4.917\end{array}$ \\
\hline 19 & $2: 1 / 1: 2: 1 \ldots \ldots$ & & 149,475 & 74.449 & 49.423 & 36.115 & 29.369 & 24.341 & 20.742 & 18.035 & 15.923 & 14.228 \\
\hline 20 & $\begin{array}{l}\text { Backcross to triple } \\
\text { recessive ........ }\end{array}$ & & 25.626 & 13.126 & 8.961 & 6.878 & 5.629 & 4.797 & 4.203 & 3.758 & 3.413 & 3.137 \\
\hline 21 & $3: 1 / 9: 7 \ldots \ldots \ldots$ & $\stackrel{\mathrm{R}}{\mathrm{C}}$ & $\begin{array}{r}0.000 \\
38.466\end{array}$ & $\begin{array}{r}0.002 \\
19.682\end{array}$ & & & & & & & $\begin{array}{l}0.030 \\
4.897\end{array}$ & $\begin{array}{l}0.037 \\
4.455\end{array}$ \\
\hline 22 & $1: 2: 1 / 9: 7 \ldots \ldots$ & & 38.911 & 20.079 & 13.821 & 10.548 & 8.614 & 7.301 & 6.350 & 5.626 & 5.054 & 4.589 \\
\hline 23 & $3: 1 / 15: 1 \ldots \ldots \ldots$ & $\stackrel{\mathrm{R}}{\mathrm{C}}$ & $\begin{array}{r}0.250 \\
12.664\end{array}$ & $\begin{array}{l}0.250 \\
6.412\end{array}$ & & & & & & & $\begin{array}{l}0.253 \\
1.537\end{array}$ & $\begin{array}{l}0.253 \\
1.396\end{array}$ \\
\hline 24 & $1: 2: 1 / 15: 1 \ldots \ldots$ & & 12.737 & 6.485 & 4.400 & 3.357 & 2.730 & 2.312 & 2.013 & 1.788 & 1.613 & 1.473 \\
\hline 25 & $3: 1 / 7: 4: 4: 1 \ldots$ & $\stackrel{\mathrm{R}}{\mathrm{C}}$ & $\begin{array}{l}38.588 \\
37.308\end{array}$ & $\begin{array}{l}19.803 \\
18.554\end{array}$ & $\begin{array}{l}13.519 \\
12.301\end{array}$ & $\begin{array}{r}10.226 \\
9.637\end{array}$ & & & & & $\begin{array}{l}5.007 \\
3.963\end{array}$ & $\begin{array}{l}4.564 \\
3.548\end{array}$ \\
\hline 26 & $1: 2: 1 / 7: 4: 4: 1$ & $\stackrel{\mathrm{R}}{\mathrm{C}}$ & & & & & & & & $\begin{array}{r}10.363 \\
9.743\end{array}$ & $\begin{array}{l}9.279 \\
8.689\end{array}$ & $\begin{array}{l}8.405 \\
7.844\end{array}$ \\
\hline 27 & $3: 1 / 13: 3$ & $\stackrel{\mathrm{R}}{\mathrm{C}}$ & $\begin{array}{r}0.750 \\
39.954\end{array}$ & $\begin{array}{r}0.751 \\
21.053\end{array}$ & $\begin{array}{r}0.751 \\
14.668\end{array}$ & $\begin{array}{r}0.753 \\
11.421\end{array}$ & & & & $\begin{array}{l}0.760 \\
6.352\end{array}$ & $\begin{array}{l}0.763 \\
5.755\end{array}$ & $\begin{array}{l}0.766 \\
5.268\end{array}$ \\
\hline 28 & $1: 2: 1 / 13: 3 \ldots \ldots$ & & 40.232 & 21.329 & 14.959 & 11.690 & 9.703 & 8.352 & 7.367 & 6.612 & 6.014 & 5.526 \\
\hline
\end{tabular}

* The error in $\sigma_{p}$ calculated from 3 decimal place tables of $i_{p}$ is a function of population size $(n)$ and the $i_{p}$ value such that $E_{\sigma p}=5 \times 10^{-4} n^{-1 / 2} i_{p}^{-3 / 2}$.

+ Formula 2 equals one half of formula 1.

$\ddagger$ Values for formula 7 are identical except that coupling and repulsion are reversed; thus at $p=0.01$ the repulsion phase value for formula 7 is 1.000 and the coupling phase value 50.251 . 


\begin{tabular}{|c|c|c|c|c|c|c|c|c|c|c|c|c|}
\hline \multirow{2}{*}{$\begin{array}{l}\text { For- } \\
\text { mula }\end{array}$} & \multirow{2}{*}{ Type of data } & \multirow{2}{*}{$\begin{array}{c}\text { Link- } \\
\text { age } \\
\text { phase }\end{array}$} & \multicolumn{10}{|c|}{ Value of $p$} \\
\hline & & & 0.11 & 0.12 & 0.13 & 0.14 & 0.15 & 0.16 & 0.17 & 0.18 & 0.19 & 0.20 \\
\hline 1 & $\begin{array}{r}\mathrm{F}_{2, \text { complete classi- }} \\
\text { fication........... }\end{array}$ & & 20.429 & 18.939 & 17.683 & 16.611 & 15.686 & 14.881 & 14.174 & 13.550 & 12.995 & 12.500 \\
\hline 3 & Backeross $(3: 1) \ldots$ & $\begin{array}{l}\mathrm{R} \\
\mathrm{C}\end{array}$ & $\begin{array}{l}4.810 \\
1.012\end{array}$ & $\begin{array}{l}4.433 \\
1.015\end{array}$ & $\begin{array}{l}4.114 \\
1.017\end{array}$ & $\begin{array}{l}3.840 \\
1.020\end{array}$ & $\begin{array}{l}3.604 \\
1.023\end{array}$ & $\begin{array}{l}3.397 \\
1.026\end{array}$ & $\begin{array}{l}3.214 \\
1.030\end{array}$ & $\begin{array}{l}3.053 \\
1.033\end{array}$ & $\begin{array}{l}2.870 \\
1.037\end{array}$ & $\begin{array}{l}2.778 \\
1.042\end{array}$ \\
\hline 4 & $\begin{array}{l}\mathrm{F}_{2}, \\
\quad 1: 2: 1: 2: 4: 2: 1: 2: 1 .\end{array}$ & & 17.942 & 16.404 & 15.099 & 13.977 & 13.002 & 12.146 & 11.388 & 10.712 & 10.106 & 9.559 \\
\hline 5 & $\mathrm{~F}_{2}, 3: 6: 3: 1: 2: 1$ & & 9.267 & 8.505 & 7.860 & 7.308 & 6.829 & 6.410 & 6.041 & 5.714 & 5.421 & 5.159 \\
\hline 6 & $\mathrm{~F}_{2}, 9: 3: 3: 1$ & $\stackrel{\mathrm{R}}{\mathrm{C}}$ & $\begin{array}{l}1.031 \\
8.904\end{array}$ & $\begin{array}{l}1.036 \\
8.144\end{array}$ & $\begin{array}{l}1.043 \\
7.502\end{array}$ & $\begin{array}{l}1.050 \\
6.950\end{array}$ & $\begin{array}{l}1.057 \\
6.473\end{array}$ & $\begin{array}{l}1.065 \\
6.054\end{array}$ & $\begin{array}{l}1.074 \\
5.685\end{array}$ & $\begin{array}{l}1.083 \\
5.357\end{array}$ & $\begin{array}{l}1.093 \\
5.063\end{array}$ & $\begin{array}{l}1.103 \\
4.798\end{array}$ \\
\hline 8 & $F_{2}, 13: 3 \ldots \ldots \ldots$ & $\stackrel{\mathrm{R}}{\mathrm{C}}$ & $\begin{array}{l}0.016 \\
4.019\end{array}$ & $\begin{array}{l}0.019 \\
3.638\end{array}$ & $\begin{array}{l}0.023 \\
3.315\end{array}$ & & $\begin{array}{l}0.030 \\
2.798\end{array}$ & $\begin{array}{l}0.035 \\
2.587\end{array}$ & $\begin{array}{l}0.039 \\
2.401\end{array}$ & $\begin{array}{l}0.044 \\
2.236\end{array}$ & $\begin{array}{l}0.049 \\
2.087\end{array}$ & $\begin{array}{l}0.055 \\
1.954\end{array}$ \\
\hline 9 & $\mathrm{~F}_{2}, 9: 3: 4 \ldots \ldots$ & $\stackrel{\mathrm{R}}{\mathrm{C}}$ & $\begin{array}{l}0.018 \\
4.094\end{array}$ & $\begin{array}{l}0.022 \\
3.712\end{array}$ & $\begin{array}{l}0.026 \\
3.388\end{array}$ & $\begin{array}{l}0.030 \\
3.110\end{array}$ & $\begin{array}{l}0.034 \\
2.869\end{array}$ & & & $\begin{array}{l}0.049 \\
2.304\end{array}$ & $\begin{array}{l}0.055 \\
2.155\end{array}$ & $\begin{array}{l}0.061 \\
2.020\end{array}$ \\
\hline 10 & $F_{2}, 15: 1 \ldots$ & $\stackrel{\mathrm{R}}{\mathrm{C}}$ & $\begin{array}{l}1.003 \\
1.247\end{array}$ & $\begin{array}{l}1.004 \\
1.240\end{array}$ & $\begin{array}{l}1.004 \\
1.233\end{array}$ & $\begin{array}{l}1.005 \\
1.227\end{array}$ & $\begin{array}{l}1.006 \\
1.220\end{array}$ & $\begin{array}{l}1.006 \\
1.214\end{array}$ & $\begin{array}{l}1.007 \\
1.208\end{array}$ & $\begin{array}{l}1.008 \\
1.202\end{array}$ & $\begin{array}{l}1.009 \\
1.195\end{array}$ & $\begin{array}{l}1.010 \\
1.190\end{array}$ \\
\hline 11 & $F_{2}, 9: 7$ & $\stackrel{\mathrm{R}}{\mathrm{C}}$ & $\begin{array}{l}0.012 \\
0.939\end{array}$ & $\begin{array}{l}0.014 \\
0.911\end{array}$ & $\begin{array}{l}0.017 \\
0.883\end{array}$ & $\begin{array}{l}0.020 \\
0.857\end{array}$ & $\begin{array}{l}0.023 \\
0.831\end{array}$ & $\begin{array}{l}0.026 \\
0.806\end{array}$ & $\begin{array}{l}0.029 \\
0.782\end{array}$ & $\begin{array}{l}0.032 \\
0.758\end{array}$ & $\begin{array}{l}0.036 \\
0.735\end{array}$ & $\begin{array}{l}0.040 \\
0.705\end{array}$ \\
\hline 12 & $\begin{array}{l}\mathrm{F}_{3} \text { from singly } \\
\text { dominant } \mathrm{F}_{2} \ldots\end{array}$ & $\stackrel{\mathrm{R}}{\mathrm{C}}$ & $\begin{array}{r}16.581 \\
5.719\end{array}$ & $\begin{array}{r}15.098 \\
5.359\end{array}$ & $\begin{array}{r}13.849 \\
5.057\end{array}$ & $\begin{array}{r}12.782 \\
4.802\end{array}$ & $\begin{array}{r}11.861 \\
4.583\end{array}$ & $\begin{array}{r}11.059 \\
4.395\end{array}$ & $\begin{array}{r}10.355 \\
4.233\end{array}$ & $\begin{array}{l}9.732 \\
4.091\end{array}$ & $\begin{array}{l}9.177 \\
3.967\end{array}$ & $\begin{array}{l}8.681 \\
3.858\end{array}$ \\
\hline 13 & $\begin{array}{l}\mathrm{F}_{3} \text { from doubly } \\
\text { dominant } \mathrm{F}_{2} ; h \\
\text { and } i \text { separated.. }\end{array}$ & $\begin{array}{l}\mathrm{R} \\
\mathrm{C}\end{array}$ & $\begin{array}{l}22.282 \\
15.660\end{array}$ & $\begin{array}{l}20.776 \\
14.675\end{array}$ & $\begin{array}{l}19.502 \\
13.881\end{array}$ & $\begin{array}{l}18.411 \\
13.193\end{array}$ & $\begin{array}{l}17.468 \\
12.603\end{array}$ & $\begin{array}{l}16.643 \\
12.093\end{array}$ & $\begin{array}{l}15.916 \\
11.649\end{array}$ & $\begin{array}{l}15.271 \\
11.261\end{array}$ & $\begin{array}{l}14.695 \\
10.919\end{array}$ & $\begin{array}{l}14.177 \\
10.618\end{array}$ \\
\hline 14 & $\begin{array}{l}\mathrm{F}_{3} \text { from doubly } \\
\quad \text { dominant } \mathrm{F}_{2} ; h \\
\text { and } i \text { not sepa- } \\
\text { rated............ }\end{array}$ & $\stackrel{\mathrm{R}}{\mathrm{C}}$ & $\begin{array}{l}17.338 \\
12.097\end{array}$ & $\begin{array}{l}15.741 \\
11.037\end{array}$ & $\begin{array}{l}14.376 \\
10.131\end{array}$ & $\begin{array}{r}13.194 \\
9.346\end{array}$ & $\begin{array}{r}12.158 \\
8.659\end{array}$ & $\begin{array}{r}11.241 \\
8.049\end{array}$ & $\begin{array}{r}10.423 \\
7.504\end{array}$ & $\begin{array}{l}9.686 \\
7.014\end{array}$ & $\begin{array}{l}9.019 \\
6.568\end{array}$ & $\begin{array}{l}8.410 \\
6.161\end{array}$ \\
\hline 15 & $\begin{array}{l}\text { Separation of } h \\
\quad \text { and } i \ldots \ldots \ldots \ldots\end{array}$ & & 6.185 & 6.429 & 6.680 & 6.940 & 7.207 & 7.481 & 7.763 & 8.052 & 8.348 & 8.651 \\
\hline 16 & $\begin{array}{l}1: 2: 1 \text { within re- } \\
\text { cessive class.... }\end{array}$ & & 5.107 & 4.735 & 4.421 & 4.153 & 3.922 & 3.720 & 3.544 & 3.388 & 3.249 & 3.125 \\
\hline 17 & $\begin{array}{l}1: 2: 1 \text { within } \\
\text { dominant class. }\end{array}$ & & 4.159 & 3.770 & 3.439 & 3.155 & 2.907 & 2.690 & 2.498 & 2.326 & 2.172 & 2.034 \\
\hline 18 & $\begin{array}{l}3: 1 / 2: 1 \ldots \ldots \\
\quad(6: 3: 2: 1)\end{array}$ & $\stackrel{\mathrm{R}}{\mathrm{C}}$ & $\begin{array}{l}8.254 \\
4.457\end{array}$ & $\begin{array}{l}7.490 \\
4.072\end{array}$ & $\begin{array}{l}6.843 \\
3.747\end{array}$ & $\begin{array}{l}6.288 \\
3.468\end{array}$ & & & & & & $\begin{array}{l}4.117 \\
2.381\end{array}$ \\
\hline 19 & $2: 1 / 1: 2: 1 \ldots \ldots$ & & 12.835 & 11.669 & 10.678 & 9.824 & 9.080 & 8.425 & 7.844 & 7.325 & 6.857 & 6.434 \\
\hline 20 & $\begin{array}{l}\text { Backcross to triple } \\
\text { recessive ........ }\end{array}$ & & 2.911 & 2.724 & 2.565 & 2.430 & 2.313 & 2.212 & 2.122 & 2.043 & 1.973 & 1.910 \\
\hline 21 & $3: 1 / 9: 7 \ldots \ldots \ldots$ & $\stackrel{\mathrm{R}}{\mathrm{C}}$ & $\begin{array}{l}0.045 \\
4.090\end{array}$ & $\begin{array}{l}0.053 \\
3.782\end{array}$ & $\begin{array}{l}0.062 \\
3.518\end{array}$ & $\begin{array}{l}0.071 \\
3.290\end{array}$ & $\begin{array}{l}0.082 \\
3.089\end{array}$ & $\begin{array}{l}0.092 \\
2.911\end{array}$ & & & $\begin{array}{l}0.128 \\
2.480\end{array}$ & $\begin{array}{l}0.142 \\
2.361\end{array}$ \\
\hline 22 & $1: 2: 1 / 9: 7 \ldots \ldots$ & & 4.203 & 3.876 & 3.596 & 3.353 & 3.140 & 2.951 & 2.783 & 2.632 & 2.496 & 2.372 \\
\hline 23 & $3: 1 / 15: 1 \ldots \ldots \ldots$ & $\stackrel{\mathrm{R}}{\mathrm{C}}$ & $\begin{array}{l}0.254 \\
1.281\end{array}$ & $\begin{array}{l}0.255 \\
1.185\end{array}$ & $\begin{array}{l}0.256 \\
1.103\end{array}$ & $\begin{array}{l}0.257 \\
1.033\end{array}$ & $\begin{array}{l}0.258 \\
0.971\end{array}$ & $\begin{array}{l}0.259 \\
0.918\end{array}$ & & & $\begin{array}{l}0.262 \\
0.790\end{array}$ & $\begin{array}{l}0.264 \\
0.756\end{array}$ \\
\hline 24 & $1: 2: 1 / 15: 1 \ldots \ldots$ & & 1.358 & 1.262 & 1.181 & 1.112 & 1.052 & 0.999 & 0.952 & 0.911 & 0.874 & 0.841 \\
\hline 25 & $3: 1 / 7: 4: 4: 1 \ldots$ & $\stackrel{\mathrm{R}}{\mathrm{C}}$ & $\begin{array}{l}4.197 \\
3.209\end{array}$ & $\begin{array}{l}3.889 \\
2.927\end{array}$ & $\begin{array}{l}3.625 \\
2.690\end{array}$ & $\begin{array}{l}3.396 \\
2.488\end{array}$ & $\begin{array}{l}3.195 \\
2.314\end{array}$ & $\begin{array}{l}3.018 \\
2.163\end{array}$ & $\begin{array}{l}2.859 \\
2.030\end{array}$ & $\begin{array}{l}2.717 \\
1.914\end{array}$ & $\begin{array}{l}2.588 \\
1.811\end{array}$ & $\begin{array}{l}2.471 \\
1.720\end{array}$ \\
\hline 26 & $1: 2: 1 / 7: 4: 4: 1$ & $\stackrel{\mathrm{R}}{\mathrm{C}}$ & $\begin{array}{l}7.685 \\
7.150\end{array}$ & $\begin{array}{l}7.081 \\
6.570\end{array}$ & $\begin{array}{l}6.566 \\
6.078\end{array}$ & $\begin{array}{l}6.121 \\
5.655\end{array}$ & $\begin{array}{l}5.733 \\
5.288\end{array}$ & $\begin{array}{l}5.391 \\
4.965\end{array}$ & $\begin{array}{l}5.087 \\
4.679\end{array}$ & $\begin{array}{l}4.814 \\
4.425\end{array}$ & $\begin{array}{l}4.569 \\
4.196\end{array}$ & $\begin{array}{l}4.347 \\
3.990\end{array}$ \\
\hline 27 & $3: 1 / 13: 3 \ldots$ & $\stackrel{\mathrm{R}}{\mathrm{C}}$ & $\begin{array}{l}0.769 \\
4.862\end{array}$ & $\begin{array}{l}0.773 \\
4.517\end{array}$ & $\begin{array}{l}0.777 \\
4.221\end{array}$ & $\begin{array}{l}0.781 \\
3.963\end{array}$ & $\begin{array}{l}0.786 \\
3.735\end{array}$ & $\begin{array}{l}0.791 \\
3.533\end{array}$ & $\begin{array}{l}0.796 \\
3.353\end{array}$ & $\begin{array}{l}0.802 \\
3.190\end{array}$ & $\begin{array}{l}0.808 \\
3.042\end{array}$ & $\begin{array}{l}0.814 \\
2.902\end{array}$ \\
\hline 28 & $1: 2: 1 / 13: 3$. & & 5.120 & 4.551 & 4.478 & 4.220 & 3.994 & 3.793 & 3.613 & 3.452 & 3.306 & 3.174 \\
\hline
\end{tabular}


TABLE 8-(Continued)

\begin{tabular}{|c|c|c|c|c|c|c|c|c|c|c|c|c|}
\hline \multirow{2}{*}{$\begin{array}{l}\text { For- } \\
\text { mula }\end{array}$} & \multirow{2}{*}{ ype of data } & \multirow{2}{*}{$\mid \begin{array}{c}\text { Link- } \\
\text { age } \\
\text { phase }\end{array}$} & \multicolumn{10}{|c|}{ Value of $p$} \\
\hline & & & 0.21 & 0.22 & 0.23 & 0.24 & 0.25 & 0.26 & 0.27 & 0.28 & 0.29 & 0.30 \\
\hline 1 & $\begin{array}{r}F_{2,} \text { complete classi- } \\
\text { fication............. }\end{array}$ & & 12.055 & 11.655 & 11.293 & 10.965 & 10.667 & 10.395 & 10.147 & 9.921 & 9.713 & 9.524 \\
\hline 3 & Backcross $(3: 1) \ldots$ & $\stackrel{\mathrm{R}}{\mathrm{C}}$ & $\begin{array}{l}2.660 \\
1.046\end{array}$ & $\begin{array}{l}2.554 \\
1.051\end{array}$ & $\begin{array}{l}2.456 \\
1.056\end{array}$ & $\begin{array}{l}2.367 \\
1.061\end{array}$ & $\begin{array}{l}2.286 \\
1.067\end{array}$ & $\begin{array}{l}2.210 \\
1.073\end{array}$ & $\begin{array}{l}2.141 \\
1.079\end{array}$ & $\begin{array}{l}2.076 \\
1.085\end{array}$ & $\begin{array}{l}2.017 \\
1.092\end{array}$ & $\begin{array}{l}1.961 \\
1.099\end{array}$ \\
\hline 4 & $\mathrm{~F}_{2}{ }_{1: 2: 1: 2: 4: 2: 1: 2: 1 . .}$ & & 9.062 & 8.610 & 8.154 & 7.816 & 7.467 & 7.144 & 6.846 & 6.569 & 6.313 & 6.076 \\
\hline 5 & $\mathrm{~F}_{2}, 3: 6: 3: 1: 2: 1$ & & 4.922 & 4.708 & 4.513 & 4.335 & 4.173 & 4.024 & 3.888 & 3.763 & 3.648 & 3.542 \\
\hline 6 & $F_{2}, 9: 3: 3: 1 .$. & $\stackrel{\mathrm{R}}{\mathrm{C}}$ & $\begin{array}{l}1.114 \\
4.546\end{array}$ & $\begin{array}{l}1.125 \\
4.341\end{array}$ & $\begin{array}{l}1.141 \\
4.141\end{array}$ & $\begin{array}{l}1.150 \\
3.959\end{array}$ & $\begin{array}{l}1.167 \\
3.791\end{array}$ & $\begin{array}{l}1.178 \\
3.636\end{array}$ & $\begin{array}{l}1.192 \\
3.492\end{array}$ & $\begin{array}{l}1.208 \\
3.359\end{array}$ & $\begin{array}{l}1.224 \\
3.234\end{array}$ & $\begin{array}{l}1.241 \\
3.118\end{array}$ \\
\hline 8 & $\mathrm{~F}_{2}, 13: 3 \ldots$ & $\stackrel{\mathrm{R}}{\mathrm{C}}$ & $\begin{array}{l}0.061 \\
1.832\end{array}$ & $\begin{array}{l}0.067 \\
1.722\end{array}$ & $\begin{array}{l}0.073 \\
1.621\end{array}$ & $\begin{array}{l}0.080 \\
1.524\end{array}$ & $\begin{array}{l}0.087 \\
1.444\end{array}$ & $\begin{array}{l}0.095 \\
1.365\end{array}$ & $\begin{array}{l}0.102 \\
1.292\end{array}$ & $\begin{array}{l}0.111 \\
1.224\end{array}$ & $\begin{array}{l}0.119 \\
1.160\end{array}$ & $\begin{array}{l}0.128 \\
1.101\end{array}$ \\
\hline 9 & $F_{2}, 9: 3: 4 \ldots$ & $\stackrel{\mathrm{R}}{\mathrm{C}}$ & $\begin{array}{l}0.068 \\
1.898\end{array}$ & $\begin{array}{l}0.074 \\
1.787\end{array}$ & $\begin{array}{l}0.082 \\
1.685\end{array}$ & $\begin{array}{l}0.089 \\
1.592\end{array}$ & $\begin{array}{l}0.097 \\
1.505\end{array}$ & $\begin{array}{l}0.105 \\
1.425\end{array}$ & $\begin{array}{l}0.114 \\
1.345\end{array}$ & $\begin{array}{l}0.123 \\
1.282\end{array}$ & $\begin{array}{l}0.132 \\
1.218\end{array}$ & $\begin{array}{l}0.142 \\
1.158\end{array}$ \\
\hline 10 & $\mathrm{~F}_{2}, 15: 1 \ldots$ & $\stackrel{\mathrm{R}}{\mathrm{C}}$ & $\begin{array}{l}1.011 \\
1.185\end{array}$ & $\begin{array}{l}1.012 \\
1.179\end{array}$ & $\begin{array}{l}1.013 \\
1.174\end{array}$ & $\begin{array}{l}1.015 \\
1.169\end{array}$ & $\begin{array}{l}1.016 \\
1.164\end{array}$ & $\begin{array}{l}1.017 \\
1.159\end{array}$ & $\begin{array}{l}1.019 \\
1.154\end{array}$ & $\begin{array}{l}1.020 \\
1.149\end{array}$ & $\begin{array}{l}1.021 \\
1.144\end{array}$ & $\begin{array}{l}1.023 \\
1.140\end{array}$ \\
\hline 11 & $\mathrm{~F}_{2}, 9: 7 \ldots$ & $\stackrel{\mathrm{R}}{\mathrm{C}}$ & $\begin{array}{l}0.044 \\
0.691\end{array}$ & $\begin{array}{l}0.048 \\
0.670\end{array}$ & $\begin{array}{l}0.053 \\
0.650\end{array}$ & $\begin{array}{l}0.058 \\
0.628\end{array}$ & $\begin{array}{l}0.063 \\
0.611\end{array}$ & $\begin{array}{l}0.068 \\
0.592\end{array}$ & $\begin{array}{l}0.073 \\
0.574\end{array}$ & $\begin{array}{l}0.079 \\
0.556\end{array}$ & $\begin{array}{l}0.084 \\
0.538\end{array}$ & $\begin{array}{l}0.090 \\
0.521\end{array}$ \\
\hline 12 & $\begin{array}{l}\mathrm{F}_{3} \text { from singly } \\
\text { dominat } \mathrm{F}_{2} \ldots\end{array}$ & $\stackrel{\mathrm{R}}{\mathrm{C}}$ & $\begin{array}{l}8.234 \\
3.763\end{array}$ & $\begin{array}{l}7.831 \\
3.679\end{array}$ & $\begin{array}{l}7.465 \\
3.605\end{array}$ & $\begin{array}{l}7.131 \\
3.540\end{array}$ & $\begin{array}{l}6.827 \\
3.483\end{array}$ & $\begin{array}{l}6.548 \\
3.433\end{array}$ & $\begin{array}{l}6.291 \\
3.390\end{array}$ & $\begin{array}{l}6.055 \\
3.353\end{array}$ & $\begin{array}{l}5.837 \\
3.322\end{array}$ & $\begin{array}{l}5.635 \\
3.295\end{array}$ \\
\hline 13 & $\begin{array}{l}\mathrm{F}_{3} \text { from doubly } \\
\quad \text { dominant } \mathrm{F}_{2} ; h \\
\text { and } i \text { separated.. }\end{array}$ & $\stackrel{\mathrm{R}}{\mathrm{C}}$ & $\begin{array}{l}13.710 \\
10.350\end{array}$ & $\begin{array}{l}13.286 \\
10.112\end{array}$ & $\begin{array}{r}12.900 \\
9.901\end{array}$ & $\begin{array}{r}12.548 \\
9.712\end{array}$ & $\begin{array}{r}12.224 \\
9.544\end{array}$ & $\begin{array}{r}11.927 \\
9.393\end{array}$ & $\begin{array}{r}11.652 \\
9.259\end{array}$ & $\begin{array}{r}11.398 \\
9.140\end{array}$ & $\begin{array}{r}11.163 \\
9.034\end{array}$ & $\begin{array}{r}10.945 \\
8.940\end{array}$ \\
\hline 14 & $\begin{array}{l}\mathrm{F}_{3} \text { from doubly } \\
\text { dominant } \mathrm{F}_{2} ; h \\
\text { and } i \text { not sepa- } \\
\text { rated................... }\end{array}$ & $\stackrel{\mathrm{R}}{\mathrm{C}}$ & $\begin{array}{l}7.853 \\
5.788\end{array}$ & $\begin{array}{l}7.340 \\
5.443\end{array}$ & $\begin{array}{l}6.866 \\
5.123\end{array}$ & $\begin{array}{l}6.427 \\
4.826\end{array}$ & $\begin{array}{l}6.018 \\
4.548\end{array}$ & $\begin{array}{l}5.637 \\
4.289\end{array}$ & $\begin{array}{l}5.281 \\
4.046\end{array}$ & $\begin{array}{l}4.949 \\
3.817\end{array}$ & $\begin{array}{l}4.637 \\
3.602\end{array}$ & $\begin{array}{l}4.346 \\
3.401\end{array}$ \\
\hline 15 & $\begin{array}{l}\text { Separation of } h \\
\quad \text { and } i \ldots \ldots \ldots \ldots\end{array}$ & & 8.959 & 9.272 & 9.591 & 9.914 & 10.240 & 10.569 & 10.899 & 11.236 & 11.561 & 11.891 \\
\hline 16 & $\begin{array}{l}1: 2: 1 \text { within re- } \\
\text { cessive class.... }\end{array}$ & & 3.014 & 2.914 & 2.823 & 2.741 & 2.667 & 2.599 & 2.537 & 2.480 & 2.428 & 2.381 \\
\hline 17 & $\begin{array}{l}1: 2: 1 \text { within } \\
\text { dominant class. }\end{array}$ & & 1.908 & 1.794 & 1.689 & 1.594 & 1.506 & 1.426 & 1.351 & 1.283 & 1.219 & 1.161 \\
\hline 18 & 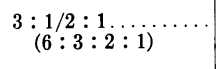 & $\stackrel{\mathrm{R}}{\mathrm{C}}$ & $\begin{array}{l}3.876 \\
2.262\end{array}$ & $\begin{array}{l}3.657 \\
2.154\end{array}$ & $\begin{array}{l}3.457 \\
2.056\end{array}$ & $\begin{array}{l}3.274 \\
1.968\end{array}$ & $\begin{array}{l}3.106 \\
1.887\end{array}$ & $\begin{array}{l}2.952 \\
1.814\end{array}$ & $\begin{array}{l}2.809 \\
1.747\end{array}$ & $\begin{array}{l}2.678 \\
1.686\end{array}$ & $\begin{array}{l}2.556 \\
1.631\end{array}$ & $\begin{array}{l}2.443 \\
1.581\end{array}$ \\
\hline 19 & $2: 1 / 1: 2: 1 \ldots \ldots \ldots$ & & 6.048 & 5.696 & 5.373 & 5.075 & 4.800 & 4.545 & 4.309 & 4.089 & 3.885 & 3.695 \\
\hline 20 & $\begin{array}{l}\text { Backcross to triple } \\
\text { recessive........ }\end{array}$ & & 1.862 & 1.802 & 1.756 & 1.714 & 1.676 & 1.641 & 1.610 & 1.581 & 1.554 & 1.530 \\
\hline 21 & $3: 1 / 9: 7 \ldots$ & $\stackrel{\mathrm{R}}{\mathrm{C}}$ & $\begin{array}{l}0.155 \\
2.253\end{array}$ & $\begin{array}{l}0.170 \\
2.153\end{array}$ & $\begin{array}{l}0.184 \\
2.060\end{array}$ & $\begin{array}{l}0.200 \\
1.974\end{array}$ & $\begin{array}{l}0.215 \\
1.893\end{array}$ & $\begin{array}{l}0.230 \\
1.818\end{array}$ & $\begin{array}{l}0.248 \\
1.747\end{array}$ & $\begin{array}{l}0.266 \\
1.681\end{array}$ & $\begin{array}{l}0.283 \\
1.618\end{array}$ & $\begin{array}{l}0.301 \\
1.558\end{array}$ \\
\hline 22 & $1: 2: 1 / 9: 7 .$. & & 2.259 & 2.158 & 2.063 & 1.978 & 1.899 & 1.826 & 1.759 & 1.697 & 1.640 & 1.587 \\
\hline 23 & $3: 1 / 15: 1 \ldots$ & $\stackrel{\mathrm{R}}{\mathrm{C}}$ & $\begin{array}{l}0.265 \\
0.725\end{array}$ & $\begin{array}{l}0.267 \\
0.697\end{array}$ & $\begin{array}{l}0.269 \\
0.670\end{array}$ & $\begin{array}{l}0.270 \\
0.647\end{array}$ & $\begin{array}{l}0.272 \\
0.625\end{array}$ & $\begin{array}{l}0.274 \\
0.604\end{array}$ & $\begin{array}{l}0.276 \\
0.585\end{array}$ & $\begin{array}{l}0.278 \\
0.568\end{array}$ & $\begin{array}{l}0.280 \\
0.551\end{array}$ & $\begin{array}{l}0.283 \\
0.536\end{array}$ \\
\hline 24 & $1: 2: 1 / 15: 1 \ldots \ldots$ & & 0.812 & 0.785 & 0.760 & 0.738 & 0.717 & 0.699 & 0.682 & 0.666 & 0.652 & 0.638 \\
\hline 25 & $3: 1 / 7: 4: 4: 1 \ldots$ & $\stackrel{\mathrm{R}}{\mathrm{C}}$ & $\begin{array}{l}2.363 \\
1.639\end{array}$ & $\begin{array}{l}2.265 \\
1.566\end{array}$ & $\begin{array}{l}2.174 \\
1.501\end{array}$ & $\begin{array}{l}2.091 \\
1.443\end{array}$ & $\begin{array}{l}2.013 \\
1.391\end{array}$ & $\begin{array}{l}1.940 \\
1.344\end{array}$ & $\begin{array}{l}1.873 \\
1.302\end{array}$ & $\begin{array}{l}1.804 \\
1.264\end{array}$ & $\begin{array}{l}1.751 \\
1.231\end{array}$ & $\begin{array}{l}1.696 \\
1.201\end{array}$ \\
\hline 26 & $1: 2: 1 / 7: 4: 4: 1$ & $\stackrel{\mathrm{R}}{\mathrm{C}}$ & & $\begin{array}{l}3.960 \\
3.633\end{array}$ & $\begin{array}{l}3.791 \\
3.477\end{array}$ & $\begin{array}{l}3.634 \\
3.334\end{array}$ & $\begin{array}{l}3.490 \\
3.203\end{array}$ & $\begin{array}{l}3.356 \\
3.082\end{array}$ & $\begin{array}{l}3.232 \\
2.970\end{array}$ & $\begin{array}{l}3.116 \\
2.868\end{array}$ & $\begin{array}{l}3.008 \\
2.772\end{array}$ & $\begin{array}{l}2.908 \\
2.684\end{array}$ \\
\hline 27 & $3: 1 / 13: 3$. & $\stackrel{\mathrm{R}}{\mathrm{C}}$ & $\begin{array}{l}0.821 \\
2.784\end{array}$ & $\begin{array}{l}0.828 \\
2.671\end{array}$ & $\begin{array}{l}0.836 \\
2.567\end{array}$ & $\begin{array}{l}0.844 \\
2.470\end{array}$ & $\begin{array}{l}0.852 \\
2.380\end{array}$ & $\begin{array}{l}0.861 \\
2.296\end{array}$ & $\begin{array}{l}0.870 \\
2.218\end{array}$ & $\begin{array}{l}0.880 \\
2.145\end{array}$ & $\begin{array}{l}0.890 \\
2.076\end{array}$ & $\begin{array}{l}0.900 \\
2.012\end{array}$ \\
\hline 28 & $1: 2: 1 / 13: 3 \ldots$ & & 3.054 & 2.944 & 2.844 & 2.751 & 2.666 & 2.588 & 2.515 & 2.448 & 2.383 & 2.329 \\
\hline
\end{tabular}




\begin{tabular}{|c|c|c|c|c|c|c|c|c|c|c|c|c|}
\hline \multirow{2}{*}{$\begin{array}{l}\text { For- } \\
\text { mula }\end{array}$} & \multirow{2}{*}{ Type of data } & \multirow{2}{*}{$\begin{array}{c}\text { Link- } \\
\text { age } \\
\text { phase }\end{array}$} & \multicolumn{10}{|c|}{ Value of $p$} \\
\hline & & & 0.31 & 0.32 & 0.33 & 0.34 & 0.35 & 0.36 & 0.37 & 0.38 & 0.39 & 0.40 \\
\hline 1 & $\begin{array}{r}\mathrm{F}_{2, \text { complete classi- }} \\
\text { fication......... }\end{array}$ & & 9.350 & 9.191 & 9.046 & 8.913 & 8.791 & 8.681 & 8.580 & 8.489 & 8.407 & 8.333 \\
\hline 3 & Backeross $(3: 1) \ldots$ & $\begin{array}{l}\mathrm{R} \\
\mathrm{C}\end{array}$ & $\begin{array}{l}1.909 \\
1.106\end{array}$ & $\begin{array}{l}1.860 \\
1.114\end{array}$ & $\begin{array}{l}1.815 \\
1.122\end{array}$ & $\begin{array}{l}1.772 \\
1.131\end{array}$ & $\begin{array}{l}1.732 \\
1.140\end{array}$ & $\begin{array}{l}1.694 \\
1.149\end{array}$ & $\begin{array}{l}1.658 \\
1.159\end{array}$ & $\begin{array}{l}1.624 \\
1.169\end{array}$ & $\begin{array}{l}1.593 \\
1.179\end{array}$ & $\begin{array}{l}1.563 \\
1.190\end{array}$ \\
\hline 4 & $\begin{array}{l}\mathrm{F}_{2}, \\
\quad 1: 2: 1: 2: 4: 2: 1: 2: 1\end{array}$ & & 5.855 & 5.650 & 5.461 & 5.284 & 5.121 & 4.971 & 4.833 & 4.707 & 4.592 & 4.487 \\
\hline 5 & $\mathrm{~F}_{2}, 3: 6: 3: 1: 2: 1$ & & 3.444 & 3.350 & 3.243 & 3.197 & 3.127 & 3.064 & 3.006 & 2.953 & 2.905 & 2.863 \\
\hline 6 & $\mathrm{~F}_{2}, 9: 3: 3: 1 \ldots$ & $\stackrel{\mathrm{R}}{\mathrm{C}}$ & $\begin{array}{l}1.258 \\
3.010\end{array}$ & $\begin{array}{l}1.277 \\
2.908\end{array}$ & $\begin{array}{l}1.296 \\
2.812\end{array}$ & $\begin{array}{l}1.316 \\
2.722\end{array}$ & $\begin{array}{l}1.337 \\
2.638\end{array}$ & $\begin{array}{l}1.359 \\
2.558\end{array}$ & $\begin{array}{l}1.381 \\
2.482\end{array}$ & $\begin{array}{l}1.405 \\
2.410\end{array}$ & $\begin{array}{l}1.429 \\
2.342\end{array}$ & $\begin{array}{l}1.455 \\
2.278\end{array}$ \\
\hline 8 & $F_{2}, 13: 3 \ldots$ & $\begin{array}{l}\mathrm{R} \\
\mathrm{C}\end{array}$ & $\begin{array}{l}0.137 \\
1.046\end{array}$ & $\begin{array}{l}0.147 \\
0.994\end{array}$ & $\begin{array}{l}0.157 \\
0.945\end{array}$ & $\begin{array}{l}0.168 \\
0.899\end{array}$ & $\begin{array}{l}0.179 \\
0.855\end{array}$ & $\begin{array}{l}0.190 \\
0.814\end{array}$ & $\begin{array}{l}0.202 \\
0.775\end{array}$ & $\begin{array}{l}0.215 \\
0.738\end{array}$ & $\begin{array}{l}0.228 \\
0.703\end{array}$ & $\begin{array}{l}0.241 \\
0.670\end{array}$ \\
\hline 9 & $F_{2}, 9: 3: 4 \ldots$ & $\stackrel{\mathrm{R}}{\mathrm{C}}$ & $\begin{array}{l}0.152 \\
1.101\end{array}$ & $\begin{array}{l}0.163 \\
1.048\end{array}$ & $\begin{array}{l}0.174 \\
0.998\end{array}$ & $\begin{array}{l}0.185 \\
0.951\end{array}$ & $\begin{array}{l}0.197 \\
0.906\end{array}$ & $\begin{array}{l}0.210 \\
0.864\end{array}$ & $\begin{array}{l}0.223 \\
0.824\end{array}$ & $\begin{array}{l}0.236 \\
0.786\end{array}$ & $\begin{array}{l}0.250 \\
0.749\end{array}$ & $\begin{array}{l}0.265 \\
0.715\end{array}$ \\
\hline 10 & $\mathrm{~F}_{2}, 15: 1 \ldots$ & $\stackrel{\mathrm{R}}{\mathrm{C}}$ & $\begin{array}{l}1.025 \\
1.135\end{array}$ & $\begin{array}{l}1.026 \\
1.131\end{array}$ & $\begin{array}{l}1.028 \\
1.126\end{array}$ & $\begin{array}{l}1.030 \\
1.122\end{array}$ & $\begin{array}{l}1.032 \\
1.118\end{array}$ & $\begin{array}{l}1.033 \\
1.114\end{array}$ & $\begin{array}{l}1.035 \\
1.110\end{array}$ & $\begin{array}{l}1.037 \\
1.106\end{array}$ & $\begin{array}{l}1.040 \\
1.103\end{array}$ & $\begin{array}{l}1.042 \\
1.099\end{array}$ \\
\hline 11 & $F_{2}, 9: 7$ & $\begin{array}{l}\mathrm{R} \\
\mathrm{C}\end{array}$ & $\begin{array}{l}0.096 \\
0.505\end{array}$ & $\begin{array}{l}0.103 \\
0.489\end{array}$ & $\begin{array}{l}0.109 \\
0.473\end{array}$ & $\begin{array}{l}0.116 \\
0.457\end{array}$ & $\begin{array}{l}0.123 \\
0.442\end{array}$ & $\begin{array}{l}0.130 \\
0.428\end{array}$ & $\begin{array}{l}0.138 \\
0.413\end{array}$ & $\begin{array}{l}0.145 \\
0.399\end{array}$ & $\begin{array}{l}0.153 \\
0.385\end{array}$ & $\begin{array}{l}0.161 \\
0.372\end{array}$ \\
\hline 12 & $\begin{array}{l}\mathrm{F}_{3} \text { from singly } \\
\text { dominant } \mathrm{F}_{2} \ldots\end{array}$ & $\begin{array}{l}\mathrm{R} \\
\mathrm{C}\end{array}$ & $\begin{array}{l}5.449 \\
3.274\end{array}$ & $\begin{array}{l}5.275 \\
3.257\end{array}$ & $\begin{array}{l}5.114 \\
3.244\end{array}$ & $\begin{array}{l}4.964 \\
3.234\end{array}$ & $\begin{array}{l}4.824 \\
3.229\end{array}$ & $\begin{array}{l}4.693 \\
3.227\end{array}$ & $\begin{array}{l}4.571 \\
3.229\end{array}$ & $\begin{array}{l}4.458 \\
3.235\end{array}$ & $\begin{array}{l}4.351 \\
3.243\end{array}$ & $\begin{array}{l}4.252 \\
3.255\end{array}$ \\
\hline 13 & $\begin{array}{l}\mathrm{F}_{3} \text { from doubly } \\
\text { dominant } \mathrm{F}_{2} ; h \\
\text { and } i \text { separated.. }\end{array}$ & $\begin{array}{l}\mathrm{R} \\
\mathrm{C}\end{array}$ & $\begin{array}{r}10.742 \\
8.857\end{array}$ & $\begin{array}{r}10.553 \\
8.785\end{array}$ & $\begin{array}{r}10.377 \\
8.722\end{array}$ & $\begin{array}{r}10.213 \\
8.667\end{array}$ & $\begin{array}{r}10.060 \\
8.621\end{array}$ & $\begin{array}{l}9.916 \\
8.583\end{array}$ & $\begin{array}{l}9.782 \\
8.552\end{array}$ & $\begin{array}{l}9.657 \\
8.528\end{array}$ & $\begin{array}{l}9.540 \\
8.510\end{array}$ & $\begin{array}{l}9.431 \\
8.499\end{array}$ \\
\hline 14 & $\begin{array}{l}\mathrm{F}_{3} \text { from doubly } \\
\text { dominant } \mathrm{F}_{2} ; h \\
\text { and } i \text { not sepa- } \\
\text { rated............... }\end{array}$ & $\stackrel{\mathrm{R}}{\mathrm{C}}$ & $\begin{array}{l}4.072 \\
3.211\end{array}$ & $\begin{array}{l}3.816 \\
3.032\end{array}$ & $\begin{array}{l}3.577 \\
2.865\end{array}$ & $\begin{array}{l}3.353 \\
2.708\end{array}$ & $\begin{array}{l}3.144 \\
2.562\end{array}$ & $\begin{array}{l}2.949 \\
2.426\end{array}$ & $\begin{array}{l}2.769 \\
2.299\end{array}$ & $\begin{array}{l}2.602 \\
2.183\end{array}$ & $\begin{array}{l}2.449 \\
2.076\end{array}$ & $\begin{array}{l}2.308 \\
1.980\end{array}$ \\
\hline 15 & $\begin{array}{l}\text { Separation of } h \\
\quad \text { and } i \ldots \ldots \ldots\end{array}$ & & 12.217 & 12.539 & 12.856 & 13.166 & 13.467 & 13.758 & 14.038 & 14.305 & 14.557 & 14.793 \\
\hline 16 & $\begin{array}{l}1: 2: 1 \text { within re- } \\
\text { cessive class..... }\end{array}$ & & 2.338 & 2.298 & 2.239 & 2.228 & 2.198 & 2.170 & 2.145 & 2.122 & 2.102 & 2.083 \\
\hline 17 & $\begin{array}{l}1: 2: 1 \text { within } \\
\text { dominant class. }\end{array}$ & & 1.107 & 1.052 & 1.005 & 0.969 & 0.929 & 0.894 & 0.861 & 0.831 & 0.804 & 0.779 \\
\hline 18 & $\begin{array}{l}3: 1 / 2: 1 \ldots \ldots \cdots \\
\quad(6: 3: 2: 1)\end{array}$ & $\begin{array}{l}\mathrm{R} \\
\mathrm{C}\end{array}$ & $\begin{array}{l}2.338 \\
1.536\end{array}$ & $\begin{array}{l}2.236 \\
1.495\end{array}$ & $\begin{array}{l}2.121 \\
1.458\end{array}$ & $\begin{array}{l}2.066 \\
1.425\end{array}$ & $\begin{array}{l}1.988 \\
1.396\end{array}$ & $\begin{array}{l}1.915 \\
1.370\end{array}$ & $\begin{array}{l}1.847 \\
1.348\end{array}$ & $\begin{array}{l}1.784 \\
1.329\end{array}$ & $\begin{array}{l}1.726 \\
1.313\end{array}$ & $\begin{array}{l}1.672 \\
1.300\end{array}$ \\
\hline 19 & $2: 1 / 1: 2: 1 \ldots \ldots$ & & 3.517 & 3.352 & 3.131 & 3.056 & 2.924 & 2.801 & 2.688 & 2.585 & 2.490 & 2.404 \\
\hline 20 & $\begin{array}{c}\text { Backcross to triple } \\
\text { recessive......... }\end{array}$ & & 1.508 & 1.487 & 1.468 & 1.451 & 1.436 & 1.421 & 1.408 & 1.397 & 1.386 & 1.377 \\
\hline 21 & $3: 1 / 9: 7 \ldots \ldots$ & $\begin{array}{l}\mathrm{R} \\
\mathrm{C}\end{array}$ & $\begin{array}{l}0.320 \\
1.501\end{array}$ & $\begin{array}{l}0.339 \\
1.447\end{array}$ & $\begin{array}{l}0.358 \\
1.396\end{array}$ & $\begin{array}{l}0.378 \\
1.347\end{array}$ & $\begin{array}{l}0.398 \\
1.300\end{array}$ & $\begin{array}{l}0.419 \\
1.255\end{array}$ & $\begin{array}{l}0.440 \\
1.188\end{array}$ & $\begin{array}{l}0.462 \\
1.169\end{array}$ & $\begin{array}{l}0.484 \\
1.129\end{array}$ & $\begin{array}{l}0.508 \\
1.090\end{array}$ \\
\hline 22 & $1: 2: 1 / 9: 7 \ldots \ldots$ & & 1.538 & 1.490 & 1.447 & 1.413 & 1.378 & 1.346 & 1.316 & 1.290 & 1.265 & 1.243 \\
\hline 23 & $3: 1 / 15: 1 \ldots$ & $\begin{array}{l}\mathrm{R} \\
\mathrm{C}\end{array}$ & $\begin{array}{l}0.285 \\
0.521\end{array}$ & $\begin{array}{l}0.287 \\
0.508\end{array}$ & $\begin{array}{l}0.290 \\
0.495\end{array}$ & $\begin{array}{l}0.293 \\
0.483\end{array}$ & $\begin{array}{l}0.296 \\
0.472\end{array}$ & $\begin{array}{l}0.299 \\
0.461\end{array}$ & $\begin{array}{l}0.302 \\
0.451\end{array}$ & $\begin{array}{l}0.305 \\
0.441\end{array}$ & $\begin{array}{l}0.308 \\
0.432\end{array}$ & $\begin{array}{l}0.312 \\
0.423\end{array}$ \\
\hline 24 & $1: 2: 1 / 15: 1 \ldots \ldots$ & & 0.626 & 0.615 & 0.605 & 0.595 & 0.587 & 0.579 & 0.571 & 0.565 & 0.559 & 0.554 \\
\hline 25 & $3: 1 / 7: 4: 4: 1 \ldots$ & $\stackrel{\mathrm{R}}{\mathrm{C}}$ & $\begin{array}{l}1.644 \\
1.174\end{array}$ & $\begin{array}{l}1.595 \\
1.151\end{array}$ & $\begin{array}{l}1.535 \\
1.115\end{array}$ & $\begin{array}{l}1.506 \\
1.112\end{array}$ & $\begin{array}{l}1.466 \\
1.096\end{array}$ & $\begin{array}{l}1.428 \\
1.083\end{array}$ & $\begin{array}{l}1.392 \\
1.072\end{array}$ & $\begin{array}{l}1.358 \\
1.063\end{array}$ & $\begin{array}{l}1.327 \\
1.056\end{array}$ & $\begin{array}{l}1.297 \\
1.052\end{array}$ \\
\hline 26 & $1: 2: 1 / 7: 4: 4: 1$ & $\begin{array}{l}\mathrm{R} \\
\mathrm{C}\end{array}$ & $\begin{array}{l}2.814 \\
2.602\end{array}$ & $\begin{array}{l}2.727 \\
2.535\end{array}$ & $\begin{array}{l}2.646 \\
2.456\end{array}$ & $\begin{array}{l}2.570 \\
2.392\end{array}$ & $\begin{array}{l}2.499 \\
2.332\end{array}$ & $\begin{array}{l}2.433 \\
2.278\end{array}$ & $\begin{array}{l}2.372 \\
2.228\end{array}$ & $\begin{array}{l}2.316 \\
2.183\end{array}$ & $\begin{array}{l}2.264 \\
2.142\end{array}$ & $\begin{array}{l}2.222 \\
2.106\end{array}$ \\
\hline 27 & $3: 1 / 13: 3$ & $\stackrel{\mathrm{R}}{\mathrm{C}}$ & $\begin{array}{l}0.911 \\
1.951\end{array}$ & $\begin{array}{l}0.923 \\
1.893\end{array}$ & $\begin{array}{l}0.935 \\
1.839\end{array}$ & $\begin{array}{l}0.947 \\
1.770\end{array}$ & $\begin{array}{l}0.960 \\
1.739\end{array}$ & $\begin{array}{l}0.974 \\
1.693\end{array}$ & $\begin{array}{l}0.988 \\
1.649\end{array}$ & $\begin{array}{l}1.002 \\
1.607\end{array}$ & $\begin{array}{l}1.017 \\
1.568\end{array}$ & $\begin{array}{l}1.033 \\
1.530\end{array}$ \\
\hline 28 & $1: 2: 1 / 13: 3 \ldots \ldots$ & & 2.276 & 2.227 & 2.182 & 2.141 & 2.103 & 2.068 & 2.035 & 2.006 & 1.980 & 1.956 \\
\hline
\end{tabular}


TABLE 8-(Concluded $)$

\begin{tabular}{|c|c|c|c|c|c|c|c|c|c|c|c|c|}
\hline \multirow{2}{*}{$\begin{array}{l}\text { For- } \\
\text { mula }\end{array}$} & \multirow{2}{*}{ Type of data } & \multirow{2}{*}{$\begin{array}{c}\text { Link- } \\
\text { age } \\
\text { phase }\end{array}$} & \multicolumn{10}{|c|}{ Value of $p$} \\
\hline & & & 0.41 & 0.42 & 0.43 & 0.44 & 0.45 & 0.46 & 0.47 & 0.48 & 0.49 & 0.50 \\
\hline 1 & $\begin{array}{r}F_{2} \text {, complete classi- } \\
\quad \text { fication.......... }\end{array}$ & & 8.268 & 8.210 & 8.160 & 8.117 & 8.081 & 8.052 & 8.029 & 8.009 & 8.003 & 8.000 \\
\hline 3 & Backeross $(3: 1) \ldots$ & $\stackrel{\mathrm{R}}{\mathrm{C}}$ & $\begin{array}{l}1.534 \\
1.202\end{array}$ & $\begin{array}{l}1.507 \\
1.214\end{array}$ & $\begin{array}{l}1.481 \\
1.227\end{array}$ & $\begin{array}{l}1.457 \\
1.240\end{array}$ & $\begin{array}{l}1.434 \\
1.254\end{array}$ & $\begin{array}{l}1.412 \\
1.268\end{array}$ & $\begin{array}{l}1.391 \\
1.284\end{array}$ & $\begin{array}{l}1.371 \\
1.299\end{array}$ & $\begin{array}{l}1.352 \\
1.316\end{array}$ & $\begin{array}{l}1.333 \\
1.333\end{array}$ \\
\hline 4 & $\begin{array}{l}\mathrm{F}_{2}, \\
\quad 1: 2: 1: 2: 4: 2: 1: 2: 1 \ldots\end{array}$ & & 4.393 & 4.310 & 4.237 & 4.174 & 4.120 & 4.077 & 4.043 & 4.019 & 4.005 & 4.000 \\
\hline 5 & $\mathrm{~F}_{2}, 3: 6: 3: 1: 2: 1$ & & 2.824 & 2.791 & 2.761 & 2.736 & 2.714 & 2.697 & 2.684 & 2.674 & 2.669 & 2.667 \\
\hline 6 & $\mathrm{~F}_{2}, 9: 3: 3: 1 \ldots$ & $\stackrel{\mathrm{R}}{\mathrm{C}}$ & $\begin{array}{l}1.482 \\
2.216\end{array}$ & $\begin{array}{l}1.510 \\
2.158\end{array}$ & $\begin{array}{l}1.538 \\
2.102\end{array}$ & $\begin{array}{l}1.568 \\
2.049\end{array}$ & $\begin{array}{l}1.598 \\
1.999\end{array}$ & $\begin{array}{l}1.632 \\
1.951\end{array}$ & $\begin{array}{l}1.667 \\
1.904\end{array}$ & $\begin{array}{l}1.702 \\
1.860\end{array}$ & $\begin{array}{l}1.739 \\
1.818\end{array}$ & $\begin{array}{l}1.778 \\
1.778\end{array}$ \\
\hline 8 & $\mathrm{~F}_{2}, 13: 3 \ldots$ & $\stackrel{\mathrm{R}}{\mathrm{C}}$ & $\begin{array}{l}0.255 \\
0.638\end{array}$ & $\begin{array}{l}0.270 \\
0.608\end{array}$ & $\begin{array}{l}0.285 \\
0.579\end{array}$ & $\begin{array}{l}0.301 \\
0.552\end{array}$ & $\begin{array}{l}0.317 \\
0.525\end{array}$ & $\begin{array}{l}0.334 \\
0.500\end{array}$ & $\begin{array}{l}0.352 \\
0.476\end{array}$ & $\begin{array}{l}0.371 \\
0.453\end{array}$ & $\begin{array}{l}0.390 \\
0.431\end{array}$ & $\begin{array}{l}0.410 \\
0.410\end{array}$ \\
\hline 9 & $\mathbf{F}_{2}, 9: 3: 4 \ldots \ldots$ & $\stackrel{\mathrm{R}}{\mathrm{C}}$ & $\begin{array}{l}0.280 \\
0.682\end{array}$ & $\begin{array}{l}0.295 \\
0.651\end{array}$ & $\begin{array}{l}0.311 \\
0.621\end{array}$ & $\begin{array}{l}0.328 \\
0.592\end{array}$ & $\begin{array}{l}0.346 \\
0.565\end{array}$ & $\begin{array}{l}0.364 \\
0.539\end{array}$ & & $\begin{array}{l}0.403 \\
0.490\end{array}$ & $\begin{array}{l}0.423 \\
0.467\end{array}$ & $\begin{array}{l}0.444 \\
0.444\end{array}$ \\
\hline 10 & $\mathrm{~F}_{2}, 15: 1, \ldots \ldots \ldots$ & $\begin{array}{l}\mathrm{R} \\
\mathrm{C}\end{array}$ & $\begin{array}{l}1.044 \\
1.095\end{array}$ & $\begin{array}{l}1.046 \\
1.092\end{array}$ & $\begin{array}{l}1.048 \\
1.088\end{array}$ & $\begin{array}{l}1.051 \\
1.085\end{array}$ & $\begin{array}{l}1.053 \\
1.082\end{array}$ & $\begin{array}{l}1.056 \\
1.079\end{array}$ & $\begin{array}{l}1.058 \\
1.076\end{array}$ & $\begin{array}{l}1.061 \\
1.073\end{array}$ & $\begin{array}{l}1.064 \\
1.070\end{array}$ & $\begin{array}{l}1.067 \\
1.067\end{array}$ \\
\hline 11 & $F_{2}, 9: 7 \ldots \ldots$ & $\begin{array}{l}\mathrm{R} \\
\mathrm{C}\end{array}$ & $\begin{array}{l}0.169 \\
0.359\end{array}$ & $\begin{array}{l}0.178 \\
0.346\end{array}$ & $\begin{array}{l}0.186 \\
0.334\end{array}$ & $\begin{array}{l}0.195 \\
0.322\end{array}$ & $\begin{array}{l}0.205 \\
0.310\end{array}$ & $\begin{array}{l}0.214 \\
0.298\end{array}$ & $\begin{array}{l}0.224 \\
0.287\end{array}$ & $\begin{array}{l}0.234 \\
0.275\end{array}$ & $\begin{array}{l}0.244 \\
0.265\end{array}$ & $\begin{array}{l}0.254 \\
0.254\end{array}$ \\
\hline 12 & $\begin{array}{l}\mathrm{F}_{3} \text { from singly } \\
\text { dominant } \mathrm{F}_{2} \ldots \ldots\end{array}$ & $\stackrel{\mathrm{R}}{\mathrm{C}}$ & $\begin{array}{l}4.159 \\
3.270\end{array}$ & $\begin{array}{l}4.072 \\
3.289\end{array}$ & $\begin{array}{l}3.990 \\
3.310\end{array}$ & $\begin{array}{l}3.914 \\
3.335\end{array}$ & $\begin{array}{l}3.843 \\
3.364\end{array}$ & $\begin{array}{l}3.777 \\
3.395\end{array}$ & $\begin{array}{l}3.716 \\
3.430\end{array}$ & $\begin{array}{l}3.658 \\
3.468\end{array}$ & $\begin{array}{l}3.605 \\
3.510\end{array}$ & $\begin{array}{l}3.556 \\
3.556\end{array}$ \\
\hline 13 & $\begin{array}{l}\mathrm{F}_{3} \text { from doubly } \\
\text { dominant } \mathrm{F}_{2} ; h \\
\text { and } i \text { separated. }\end{array}$ & $\stackrel{\mathrm{R}}{\mathrm{C}}$ & $\begin{array}{l}9.329 \\
8.493\end{array}$ & $\begin{array}{l}9.234 \\
8.487\end{array}$ & $\begin{array}{l}9.135 \\
8.500\end{array}$ & $\begin{array}{l}9.063 \\
8.511\end{array}$ & $\begin{array}{l}8.987 \\
8.528\end{array}$ & $\begin{array}{l}8.917 \\
8.550\end{array}$ & $\begin{array}{l}8.852 \\
8.578\end{array}$ & $\begin{array}{l}8.793 \\
8.610\end{array}$ & $\begin{array}{l}8.740 \\
8.648\end{array}$ & $\begin{array}{l}8.691 \\
8.691\end{array}$ \\
\hline 14 & $\begin{array}{l}\mathrm{F}_{3} \text { from doubly } \\
\text { dominant } \mathrm{F}_{2} ; h \\
\text { and } i \text { not sepa- } \\
\text { rated............. }\end{array}$ & $\stackrel{\mathrm{R}}{\mathrm{C}}$ & $\begin{array}{l}2.181 \\
1.893\end{array}$ & $\begin{array}{l}2.066 \\
1.816\end{array}$ & $\begin{array}{l}1.963 \\
1.750\end{array}$ & $\begin{array}{l}1.873 \\
1.694\end{array}$ & $\begin{array}{l}1.794 \\
1.648\end{array}$ & $\begin{array}{l}1.728 \\
1.613\end{array}$ & $\begin{array}{l}1.674 \\
1.588\end{array}$ & $\begin{array}{l}1.631 \\
1.575\end{array}$ & $\begin{array}{l}1.600 \\
1.572\end{array}$ & $\begin{array}{l}1.580 \\
1.580\end{array}$ \\
\hline 15 & $\begin{array}{l}\text { Separation of } h \\
\quad \text { and } i \ldots \ldots \ldots \ldots\end{array}$ & & 15.012 & 15.211 & 15.391 & 15.549 & 15.685 & 15.797 & 15.885 & 15.949 & 15.987 & 16.000 \\
\hline 16 & $\begin{array}{l}1: 2: 1 \text { within re- } \\
\text { cessive class..... }\end{array}$ & & 2.067 & 2.053 & 2.040 & 2.029 & 2.020 & 2.013 & 2.007 & 2.003 & 2.001 & 2.000 \\
\hline 17 & $\begin{array}{l}1: 2: 1 \text { within } \\
\text { dominant class }\end{array}$ & & 0.757 & 0.738 & 0.721 & 0.707 & 0.694 & 0.684 & 0.677 & 0.671 & 0.668 & 0.667 \\
\hline 18 & $\begin{array}{l}3: 1 / 2: 1 \ldots: 1) \\
\quad(6: 3: 2: 1)\end{array}$ & $\begin{array}{l}\mathrm{R} \\
\mathrm{C}\end{array}$ & $\begin{array}{l}1.622 \\
1.290\end{array}$ & $\begin{array}{l}1.576 \\
1.284\end{array}$ & $\begin{array}{l}1.534 \\
1.280\end{array}$ & $\begin{array}{l}1.496 \\
1.279\end{array}$ & $\begin{array}{l}1.461 \\
1.281\end{array}$ & $\begin{array}{l}1.429 \\
1.286\end{array}$ & & $\begin{array}{l}1.375 \\
1.304\end{array}$ & & $\begin{array}{l}1.333 \\
1.333\end{array}$ \\
\hline 19 & $2: 1 / 1: 2: 1 \ldots \ldots$ & & 2.326 & 2.257 & 2.197 & 2.144 & 2.100 & 2.064 & 2.036 & 2.016 & 2.004 & 2.000 \\
\hline 20 & $\begin{array}{l}\text { Backeross to triple } \\
\text { recessive........ }\end{array}$ & & 1.368 & 1.361 & 1.354 & 1.348 & 1.344 & 1.340 & 1.337 & 1.335 & 1.334 & 1.333 \\
\hline 21 & $3: 1 / 9: 7$ & $\stackrel{\mathrm{R}}{\mathrm{C}}$ & $\begin{array}{l}0.530 \\
1.053\end{array}$ & $\begin{array}{l}0.554 \\
1.017\end{array}$ & $\begin{array}{l}0.578 \\
0.981\end{array}$ & $\begin{array}{l}0.602 \\
0.947\end{array}$ & & $\begin{array}{l}0.653 \\
0.882\end{array}$ & & $\begin{array}{l}0.706 \\
0.820\end{array}$ & $\begin{array}{l}0.734 \\
0.791\end{array}$ & $\begin{array}{l}0.762 \\
0.762\end{array}$ \\
\hline 22 & $1: 2: 1 / 9: 7 \ldots \ldots$ & & 1.224 & 1.206 & 1.191 & 1.178 & 1.167 & 1.159 & 1.152 & 1.147 & 1.144 & 1.143 \\
\hline 23 & $3: 1 / 15: 1 \ldots \ldots \ldots$ & $\underset{\mathrm{C}}{\mathrm{R}}$ & $\begin{array}{l}0.315 \\
0.415\end{array}$ & $\begin{array}{l}0.319 \\
0.407\end{array}$ & $\begin{array}{l}0.323 \\
0.400\end{array}$ & $\begin{array}{l}0.327 \\
0.392\end{array}$ & $\begin{array}{l}0.331 \\
0.386\end{array}$ & $\begin{array}{l}0.336 \\
0.379\end{array}$ & $\begin{array}{l}0.340 \\
0.373\end{array}$ & $\begin{array}{l}0.345 \\
0.367\end{array}$ & $\begin{array}{l}0.350 \\
0.361\end{array}$ & $\begin{array}{l}0.356 \\
0.356\end{array}$ \\
\hline 24 & $1: 2: 1 / 15: 1 \ldots \ldots$ & & 0.549 & 0.545 & 0.541 & 0.538 & 0.535 & 0.533 & 0.532 & 0.530 & 0.530 & 0.529 \\
\hline 25 & $3: 1 / 7: 4: 4: 1 \ldots$ & $\underset{\mathrm{C}}{\mathrm{R}}$ & $\begin{array}{l}1.269 \\
1.048\end{array}$ & $\begin{array}{l}1.243 \\
1.047\end{array}$ & $\begin{array}{l}1.219 \\
1.048\end{array}$ & $\begin{array}{l}1.197 \\
1.050\end{array}$ & $\begin{array}{l}1.176 \\
1.053\end{array}$ & $\begin{array}{l}1.157 \\
1.059\end{array}$ & $\begin{array}{l}1.139 \\
1.065\end{array}$ & $\begin{array}{l}1.123 \\
1.074\end{array}$ & $\begin{array}{l}1.108 \\
1.084\end{array}$ & $\begin{array}{l}1.095 \\
1.095\end{array}$ \\
\hline 26 & $1: 2: 1 / 7: 4: 4: 1$ & $\stackrel{\mathrm{R}}{\mathrm{C}}$ & $\begin{array}{l}2.173 \\
2.074\end{array}$ & $\begin{array}{l}2.134 \\
2.045\end{array}$ & $\begin{array}{l}2.099 \\
2.021\end{array}$ & $\begin{array}{l}2.068 \\
2.001\end{array}$ & $\begin{array}{l}2.041 \\
1.985\end{array}$ & $\begin{array}{l}2.017 \\
1.973\end{array}$ & $\begin{array}{l}1.998 \\
1.965\end{array}$ & $\begin{array}{l}1.983 \\
1.961\end{array}$ & $\begin{array}{l}1.972 \\
1.961\end{array}$ & $\begin{array}{l}1.964 \\
1.964\end{array}$ \\
\hline 27 & $3: 1 / 13: 3 \ldots \ldots \ldots$ & $\stackrel{\mathrm{R}}{\mathrm{C}}$ & $\begin{array}{l}1.050 \\
1.493\end{array}$ & $\begin{array}{l}1.067 \\
1.459\end{array}$ & $\begin{array}{l}1.084 \\
1.426\end{array}$ & $\begin{array}{l}1.103 \\
1.394\end{array}$ & $\begin{array}{l}1.122 \\
1.364\end{array}$ & $\begin{array}{l}1.142 \\
1.335\end{array}$ & $\begin{array}{l}1.163 \\
1.307\end{array}$ & $\begin{array}{l}1.185 \\
1.281\end{array}$ & $\begin{array}{l}1.207 \\
1.255\end{array}$ & $\begin{array}{l}1.231 \\
1.231\end{array}$ \\
\hline 28 & $1: 2: 1 / 13: 3 \ldots \ldots$ & & 1.935 & 1.916 & 1.899 & 1.885 & 1.873 & 1.863 & 1.856 & 1.850 & 1.847 & 1.846 \\
\hline
\end{tabular}


The journal Hilgardia is published at irregular intervals, in volumes of about 600 pages. The number of issues per volume varies.

Subscriptions are not sold. The periodical is sent as published only to libraries, or to institutions in foreign countries having publications to offer in exchange.

You may obtain a single copy of any issue free, as long as the supply lasts; please request by volume and issue number from:

Agricultural Fublications

22 Giannini Hall

University of California

Berkeley 4 , California

The limit to nonresidents of California is 10 separate issues on a single order. A list of the issues still available will be sent on request. 


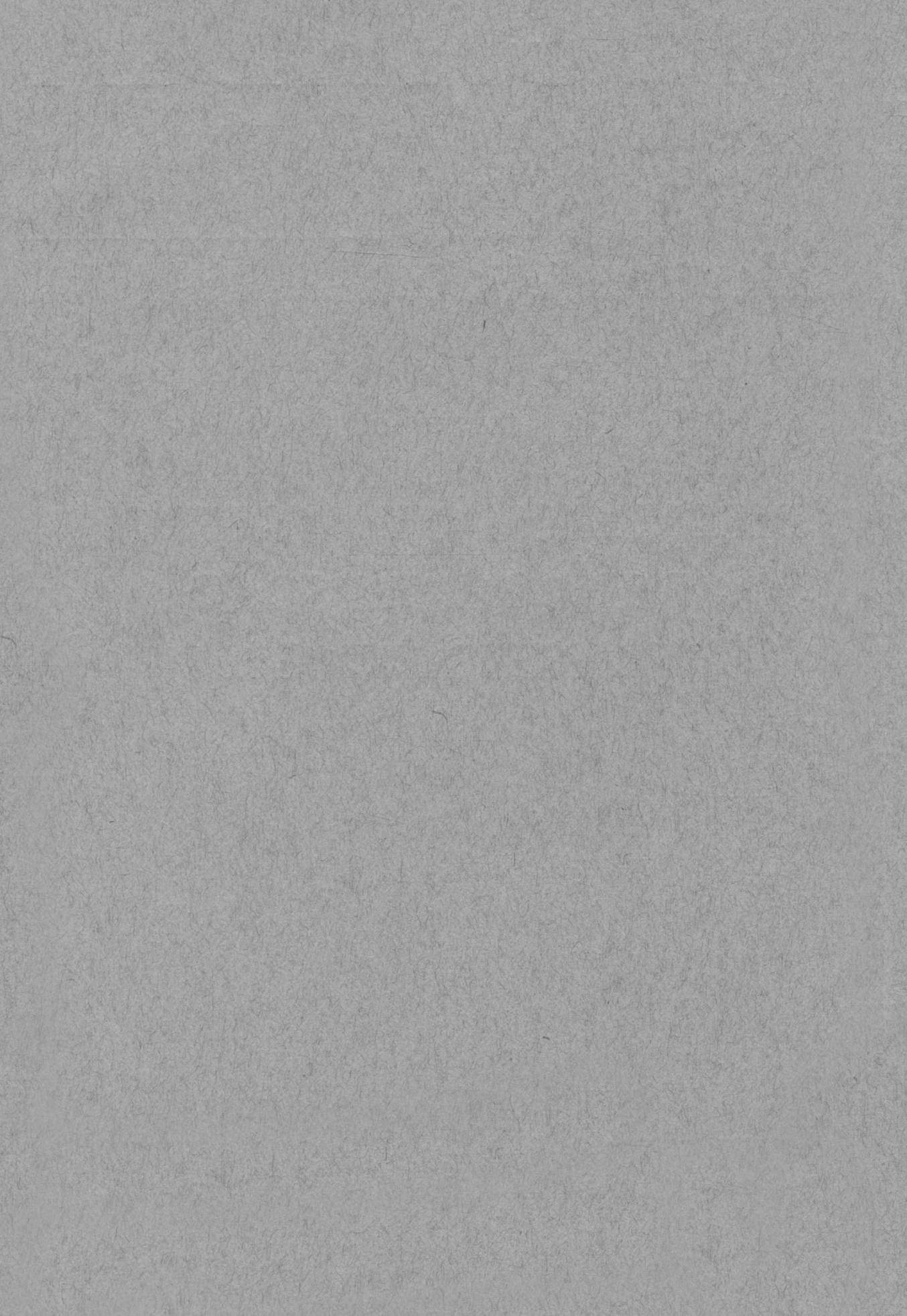

